Portland State University

PDXScholar

7-30-1982

\title{
Congressional Power and Presidential Prerogative: The War Powers Question
}

Gerald Michael Worley

Portland State University

Follow this and additional works at: https://pdxscholar.library.pdx.edu/open_access_etds

Part of the American Politics Commons, and the International Relations Commons Let us know how access to this document benefits you.

\section{Recommended Citation}

Worley, Gerald Michael, "Congressional Power and Presidential Prerogative: The War Powers Question" (1982). Dissertations and Theses. Paper 3234.

https://doi.org/10.15760/etd.3223

This Thesis is brought to you for free and open access. It has been accepted for inclusion in Dissertations and Theses by an authorized administrator of PDXScholar. Please contact us if we can make this document more accessible: pdxscholar@pdx.edu. 
AN ABSTRACT OF THE THESIS OF Gerald Michael Worley for the Master of Arts in Political Science presented July 30, 1982.

Title: Congressional Power and Presidential Prerogative: The War Powers Question.

APPROVED BY MEMBERS OF THE THESIS COMMITTEE:

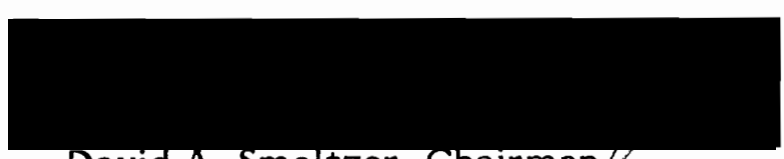

David A. Smeltzer, Chairman

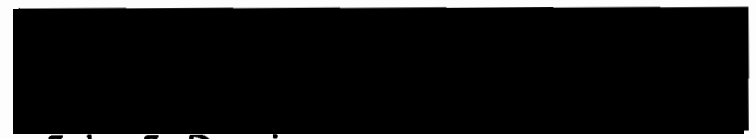

John J. Damis

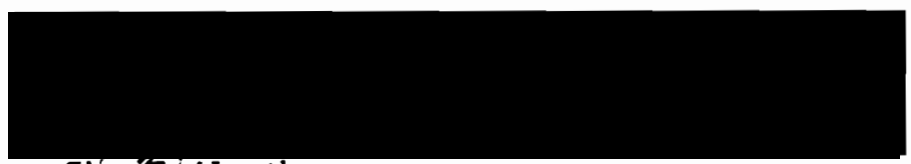

Jim Feath

This thesis is a study of the formulation of American foreign policy in general terms and specifically how hostility is initiated. War powers and who controls this authority is an age-old question. One can not simply look to the Constitution for direction. An intricate formula is necessary and the evolution of the nation must be understood.

This thesis looks at the very beginning of American constitutional government. Discussion as it surfaced in Philadelphia in 1787 is examined and interpreted. The intent of those involved in the writing of the United States Constitution is discussed. While fundamental differences emerged from the Constitutional Convention in many regards, the power to initiate war was clear. That authority belongs to the legislative branch of government and not to the executive branch. 
A study of the evolutionary process of presidential usurpation of the war-powers, including a critical look at various administrations, is helpful and included. The fact that this expansion of power exists is documented in over 200 examples of presidential war-making alluded to in Appendix I.

After having defined the problem and examined its growth, an analysis of the role set forth for the courts is reviewed. Does the judicial system have a role or is this a classic case of the "political question" doctrine. The research substantiates the claim that not only does the judiciary have a function here but that it has too of ten shrunk in the face of the war powers question. This study maintains that the courts must regain their constitutional position with regard to the justiciability of the war powers questions if Congress is to regain its lost authority.

Finally, reforms are offered, however, a major point is made regarding the attitudinal adjustments that must be made for the constitutional balance to be reached. Not only must the executive be willing to share the war-making power but just as important, a reluctant Congress must accept that responsibility.

Examination of works by leading authors on the subject, scholarly journals and periodicals, relevant newspaper articles, government documents and the United States Constitution all combine for the thoughts and notions within. 
CONGRESSIONAL POWER AND PRESIDENTIAL PREROGATIVE:

THE WAR POWERS QUESTION

by

GERALD MICHAEL WORLEY

A thesis submitted in partial fulfillment of the

requirements for the degree of

\author{
MASTER OF ARTS \\ in \\ POLITICAL SCIENCE
}

Portland State University 
TO THE OFFICE OF GR ADUATE STUDIES AND RESEARCH:

The members of the Committee approve the thesis of Gerald Michael Worley presented July 30, 1982.

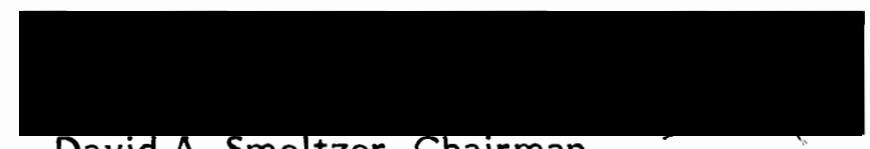

David A. Smeltzer, Chairman

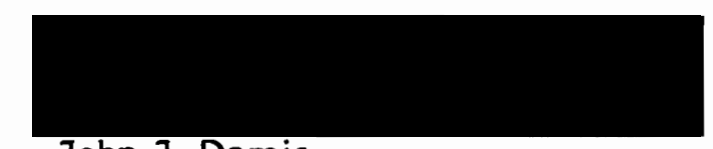

John J. Damis

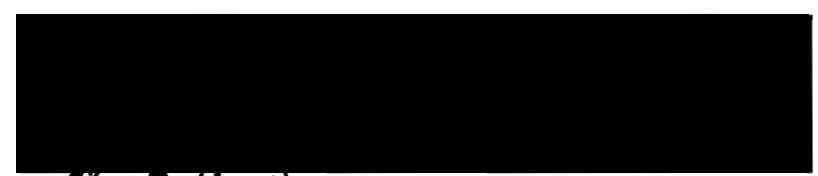

J/m/r. Heath

APPROVED:

David A. Smeltzer, Head, Department of Political Science

Stanley E."Rauch, Dean of Graduate Studies and Research 


\section{TABLE OF CONTENTS}

PAGE

Introduction 1

The Constitutional Background 3

The Intent of the Founding Fathers 6

The Courts and the Question of War 29

The Evolution of the Power to Make War 46

A Dominating President: Who is to Blame? 87

The Restoration of a Constitutional Balance 115

A Selected Bibliography 145

Appendix I - Instances of Use of United States
Armed Forces Abroad, 1798-1977

Appendix II - Public Law 93-148, War Powers
Resolution 
Foreign policy is a process of various approaches and means: military strength, power political alliances, collective security in the United Nations, foreign economic aid, social politics (foreign technical assistance and economic aid directed toward social and/or political ends, e.g. Jewish immigration from the Soviet Union), economic incentives and reprisals, trading policies designed to benefit some nations and injure others, ideological, cultural, and psychological appeals, and many more.

Foreign policy is a response to many groups, interests, values and pressures both at home and abroad. The pressures from abroad come from nations (some friendly, some unfriendly, some of varying shades of neutral), from revolutionary and counter-revolutionary movements, from alliances, and from regional and international organizations, all of which in turn must respond to internal, as well as external pressures on them.

The interests and values, groups and pressures, situations within situations, approaches and means operate simultaneously and continuously. However, the attention paid to a particular pressure, the emphasis given to this or that factor, the extent to which an approach or an instrument is used are constantly shifting as conditions change and influences rise and fall.

As a result, as a nation's foreign policy changes to meet the everfluctuating change within the international relations arena so do the relationships of the many elements. They may combine or separate in different ways and proportions, greater emphasis may be given to this element rather than that element, doctrines may be dropped or retained.

The statesman of a world power today finds himself at the center of international affairs. He has the tremendous responsibility of making the enormous and ultimate decisions in foreign policy and must try to coordinate the 
world situation into an overall pattern. Today, flanked by specialist, technocrats, methodologists, and game theorists, "informed to a degree" by the opinion polls at home and abroad, the recipient of advice and reports from all over the world, he must make decisive moves in which life and death are issues.

The problem of the control of this policy has been a perennial source of anguish for democracies. The idea of popular government hardly seems complete if it fails to embrace the question of war and peace. Yet, as Schlesinger so eloquently states, "the effective conduct of foreign affairs appears to demand not the qualities peculiar to a democracy but on the contrary, the perfect use of almost all those in which it is deficient." ${ }^{1}$ At the same time, former Secretary of State Dean Acheson, in his A Citizen Looks at Congress, concludes that it is far from easy to conduct foreign affairs in one's national interest with the restrictions and limitations imposed by the democratic political process. ${ }^{2}$ Both are quite right.

For the United States, the question of the control of foreign policy is the question of the distribution of powers between the presidency and the Congress. While this paper will initially touch on the overall control of American foreign policy, the real question to be discussed is the ultimate decision regarding foreign policy: the control of war powers. While the primary concern of this paper is the power to declare war and the power to commit military forces abroad, attention will be given to the role that Congress could play in future developments regarding foreign policy-making and the war powers. Foreign policy-making and war powers are stressed because the inquiry into the issue of the division of executive and legislative responsibilities and practices in regard

1. Arthur M. Schlesinger, "Congress and the Making of American Foreign Policy," Foreign Affairs, Vol. 51, No. 1 (October 1972), p. 78.

2. Dean Acheson, A Citizen Looks at Congress (New York: Harcourt, Brace and World, 1967), p. 84. 
to the war powers, suggest that any serious discussion of this issue must include at least some consideration of the way in which the formulation of foreign policy conditions the use of force abroad, in particular cases.

At the root of the conflict between the President and the Congress, over how much freedom the two institutions should have in foreign policy, is the doctrine of the separation of powers that is so basic to the governmental structure of the United States. Congress and the executive are in constant competition with each other for power and prestige. In the words of Edwin S. Corwin, "The Constitution is an invitation to struggle for the privilege of directing American foreign policy." ${ }^{3}$

\section{The Constitutional Background}

Whatever the obligations and rights of the United States under treaties and other elements of international law, the determination of who speaks and acts on behalf of the government of the United States is entirely a matter of internal constitutional and statutory arrangement. The Constitution vests authority to determine the course of the foreign policy of the United States is very complex, camouflaged, and misunderstood question. Corwin correctly states the case in this way, "What the Constitution does, and all that it does, is to confer on the President certain powers capable of affecting our foreign relations, and certain other powers of the same general kind on the Senate, and still other such powers on Congress." Corwin concludes noting that "which of these organs shall have the decisive and final voice in determining the course of the American nation is left for events to resolve."

3. Edwin S. Corwin, The President: Office and Power 1787-1957 (4th ed; New York: New York University Press, 1957), p. 208.

4. Ibid., p. 171. 
The actual sharing of foreign policy power between the President and the Congress within the Constitution is structured as follows.

Presidential powers in foreign relations as set forth in the Constitution

are:

Article II, section 2:

*** he shall have Power, by and with the advice and consent of the Senate to make treaties, provided two thirds of the Senators present concur;and he shall nominate, and by and with advice and consent of the Senate,shall appoint Ambassadors, other public Ministers and Consuls***

*** the President shall be Commander in Chief of the Army and Navy of the United States, and of the militia of the several States when called into the actual service of the United States***

Article II, section 3:

*** he shall receive Ambassadors and other public Ministers***

Article II, section 3, further states that the President shall see that "the Laws be faithfully executed."

Congressional powers in foreign relations as set forth in the Constitution

are:

Article 1, section 8:

The Congress. shall have power to lay and collect taxes, duties, imposts and excises, to pay the debts and provide for the common defense and general welfare of the United States,

To borrow money on the credit of the United States,

To regulate commerce with foreign nations,

To establish a uniform rule naturalization,

To coin money, regulate the value thereof, and of foreign coin,

To define and punish piracies and felonies committed on the high seas, and offenses against the law of nations,

To declare war, grant letters of marque and reprisal, and make rules concerning captures on land and water,

To raise and support Armies, but no appropriation of money to that use shall be for a longer term than two years,

To provide and maintain a navy,

To make rules for the government and regulations of the land and naval forces,

To provide for calling forth the militia to execute to laws of the Union, suppress insurrections and repel invasions,

To provide for organizing, arming and disciplining the militia, and for governing such part of them as may be employed in the service of the United States, 
To make all laws which shall be necessary and proper for carrying into execution the foregoing powers, and all other powers vested by this Constitution in the government of the United States, or in any department of officer thereof.

Article I, section 9:

No money shall be drawn from the treasury by in consequence of appropriations made by law.

In addition to these legislative powers, the Senate participates in the treaty-making process and the appointment power.

All of these powers should give the Congress a considerable voice in the determination of foreign and defense policy and the actions taken in support of them; however, this is, in reality, hardly the case. The reasons for these disparities are not clearly visable in the written text of the Constitution. The uncertainties and the sources of controversy about the Constitution lie in what the Constitution does not say. For instance, the power to make treaties is allocated to the President and the Senate, but there is no word on who has authority to terminate such a treaty. Likewise, Congress has the power to declare war yet no mention is made as to who shall possess to power to make peace.

The foremost solution to this uncertainty has been the flexibility of the written document. Some contend that one of the most unique aspects of the Constitution is its ability to endure and adapt to the changing times. They virtually ignore the written document and rely on its "spirit." One spokesman for this concept, Louis Henken, has stated that "the Constitution is not an idol but a spirit; not a form of words but a set of political attitudes and habits of behavior. Those who worship the text, worship in reality their own attitudes which they fondly hope the interpretation of the text may produce." 5 This

5. Louis Henken, "A More Effective System for Foreign Relations:The Constitution Framework," Virginia Law Review, Vol. 61, No. 747 (1975), p. 753. 
broad view of the Constitution ignores the fact that the document appears to be constructed of generalities in some areas and specific terms in others.

Even the flexibility mentioned above may not give our Constitution what it needs as an effective guide for policy-making in today's world. Former Senator J. William Fulbright raised this basic question several years ago. "The question we face is whether our basic constitutional machinery, admirably suited to the needs of a remote agrarian republic in the 18 th century, is adequate for the formulation and conduct of the foreign policy of a 20th century nation, preeminent in political and military power and burdened with all the enormous responsibilities that accompany such power." 6 Times have definitely changed. Our institutional arrangements for foreign policy were drafted in the late 18th century by men who assumed that these affairs would be few and insignificant.

The Intent of the Founding Fathers

Trying to second-guess the framers of the Constitution has been ongoing since the days of ratification. In the area of foreign policy and more specifically in the realm of war powers, this guessing game continues and has accelerated as a result of the Vietnam tragedy.

When the Philadelphia Convention convened on Monday, May 14, 1787, the delegates had ostensibly gathered for the purpose of amending the Article of Confederation, which was deemed to be defective because the states were able to act as autonomous bodies, and the national government was unable to enforce

6. J. William Fulbright, "American Foreign Policy in the 20th Century Under an 18th Century Constitution," Cornell Law Quarterly, Vol. 47, No. 1 (Fall, 1961), p. 1. 
its regulations. ${ }^{7}$ Therefore, it was essential that the powers of the national government be altered and enlarged. However, even before the Convention commenced work, the idea of drafting a Constitution for a new system of government was being discussed. ${ }^{8}$

Under the Article of Confederation, the only existent organ of national government was the Confederation Congress. Since the Congress exercised all the powers of the national government, there was no need for the Articles of Confederation to distinguish between executive and legislative powers. An early task undertaken by the Convention was to segregate the different powers of government into co-equal branches and thus change the form of government at its very roots.

During the Convention a very systematic discussion was made regarding the power to make war. It is doubtful that any group ever had thought more about how free and very diverse people ought to be governed than those men who gathered in Philadelphia to write the Constitution of the United States. The delegates were men of learning and high intelligence: Washington, Adams, Hamilton, Burke, Madison, just to name a few. These were men inspired by the thoughts of Montesquieu, Locke and the like. They had experienced revolution and had lived under several different political systems. Most importantly, they had a vested interest in coming up with a workable solution to the disruption of the past decade.

7. "The radical infirmity of the Articles of Confederation was the dependence of Congress on the voluntary and simultaneous compliance with its requisitions by so many independent communities, each consulting more or less its particular interests and convenience, and distrusting the compliance of the others." (William T. Hutchinson and William M.E. Rachel, ed., The Papers of James Madison, Vol. 2, 20 March 1780-23 February 1781 (Chicago:University of Chicago Press, 1974), p. 692).

8. Fred P. Graham, "Introduction--Toward a Jurisprudence of Peace," Boston University Law Review, Vol. 50, Special Issue (Spring, 1970), p. 11. 
They had several practical objectives in mind. First, they wished to ensure as much personal freedom as was consistent with order. Second, they hoped to prevent excessive political authority from accumulating in any one institution, for they were all skeptical of power. Third, they wanted to impose sufficient restraints on government, so as to prevent it from taking hasty, illconsidered actions. A clear philosophical background in British liberalism can be seen here. They had to create a form of government which would satisfactorily meet the interests of its subjects or face certain overthrow.

These writers of the Constitution had been raised as Englishmen, inside a colonial empire. They were accustomed to a strong executive authority that assured an ordered society which adapted slowly to changing conditions. On the other hand, their experience had fostered a deep distrust of inordinate executive power, as they felt this power being exercised by colonial governors and the English King. While they had fought a war to remove these burdens and while they did indeed dislike authority, they understood that freedom and authority were not antagonists but inseparable companions. Very clear in their minds were the upheavals during the period of the Article of Confederation. The whole idea of the Convention was to rid the country of such disorder. In short, they wisely accommodated their hopes to their fears, agreeing that while there were virtues in executive power and virtues in legislative power, there were great hazards in permitting any one authority to become dominant. With these considerations well in mind, the writers set about their task.

The plan they adopted called for dividing power equally between three branches, these being the executive, the legislative, and the judicial. Each branch was designed to provide a check on the other branches. While the coequal concept was a part of the very foundation of the Constitution, the finished 
product tended to give the pre-eminent position to the Congress, because it most nearly represented the people. Congress was the body most likely to reflect "all opinions, argue all options, and to raise objections to any suggested course of action." 9 At the same time the framers were giving Congress very clear and defined power they gave the executive many discretionary powers.

The framers must have been aware that by giving both specific and residual powers to Congress, and a somewhat undefined charter to the President, they had opened the door of conflict. How this conflict should be resolved was reasonably clear to them. Compromise, the basis of all politics, was to be sought at almost any cost but if negotiations failed overriding control would remain with Congress. In the words of a former member of Congress, "a Congress moving to reverse the policies of a President must step warily. Nevertheless, it could not ultimately be forbidden the right to circumscribe antecedent presidential action." 10

Nowhere in the Constitution did the framers make more of an effort to force the legislative and executive branches to share responsibility for policymaking than in the provisions which deal with the power to make war. In those sections they tried desperately to set up a procedure under which neither branch of the federal government could make war without the aid of the other.

Regarding the waging of war and the responsibility for military forces, in addition to the Articles mentioned above (Article I, sections 8 and 9, and Article II, sections 2 and 3), we must include Article IV, section 4 of the Constitution

9. Thomas Eagleton, War and Presidential Power:A Chronicle on Congressional Surrender (New York:Liveright Press, 1974), p. 6.

10. Ibid, p. 8. 
which deals with federal obligations to protect states. ${ }^{11}$

These provisions are clearly not a cure-all for the many questions which might emerge regarding the use of American troops or the proper response to acts of hostility or war by foreign nations. They are, instead, guidelines for cooperation between the various branches of government in the event of external dangers. Going to war was intended to be an orderly process in which deliberation would be given full play before conflict began.

The Convention, which convened on May 29, 1787, sought to separate the power to declare war from the power to conduct war, delegating the former to the legislative branch and the latter to the executive branch. Within this realm of thought, however, the founders were determined to deny the American President what Blackstone had assigned to the King of England, "the sole prerogative of making war and peace." 12

William Randolph of the Virginia delegation put forward fifteen resolutions as a basis on which the Convention could frame a new system of government. These resolutions attempted to separate legislative from executive functions. They were filled with generalities and ambiguities; for instance, Randolph's sixth resolution gave the national legislature the authority of legislative rights vested in Congress by the Confederation, while his seventh resolution gave the executive the authority to see that the laws of the nation

11. "The United States shall guarantee to every state in this union a Republican form of government, and shall protect each of them against invasion; and on application of the legislature, or of the executive, (when the legislature cannot be convened) against domestic violence," (Article IV, section 4, United States Constitution).

12. Corwin, The President: Office and Power 1787-1957), p. 154. 
were executed and he broadly stated that these executive powers had their origin in the Confederation. ${ }^{13}$

It was during this early debate that the question of war powers arose. In the course of this discussion deciding whether the national executive should be composed of a single or a multiple magistrate, it was suggested that if the national executive was composed of a single magistrate, it would not be wise to give him the powers of war and peace. Even Hamilton, the most consistent advocate of a centralized executive, proposed in the debate that the Senate should "have the sole power of declaring war" and the executive the power of "direction of war when authorized or begun." 14 There was fear within the Convention that if there was but a single magistrate, being a vigorous executive with absolute power of war and peace, he would be nothing more than an elected monarch. Even at this early date during the Convention's deliberation, it can be seen that the founding fathers were afraid of allowing a vigorous executive the powers of war and peace, which in England meant the power to declare war. ${ }^{15}$

While this debate leaned toward revolutionary changes in the system of government by which the United States functioned as a nation, there was still sympathy for merely amending the Articles of Confederation. This avenue of change also confronted the question of the power to make war. William Patterson of New Jersey proposed a scheme in which the newly created office of the executive would have the authority of "directing military activities," 16

13. Graham, "Introduction--Toward a Jurisprudence of Peace," p. 12.

14. Arthur M. Schlesinger, The Imperial Presidency (New York:Popular Library, 1974), p.3.

15. Ralph H. Gabriel, ed., The American Heritage Series--Hamilton, Madison and Jay on the Constitution:Selections from the Federalist Papers (New York:The Liberal Arts Press, 1954), pp. 144-150.

16. Graham, "Introduction--Toward a Jurisprudence of Peace," p. 13. 
implying that the Congress would retain the authority to declare war. ${ }^{17}$

The importance of considering the Patterson proposal and keeping in mind the ideas of Alexander Hamilton mentioned earlier is to recognize the fact that the Convention's main concern within the war powers question, while returning to the Randolph proposition as a basis for deliberation, was the hope of giving only limited military powers to the executive.

A first draft of the proposed Constitution was presented in early August and explicitly differentiated between the executive's military power and the military power of the legislature, authorizing the executive to be "commander in chief," while authorizing the legislative branch to "make war." The first substantive deliberation over this particular part of the draft was in regard to the wording of the authority vested in the legislative side. After much heated debate the seventh article of the draft was amended, substituting the word "declare" for "make" in the clause delegating the power to the leglslature "to make war." This substitution was made for definitional purposes. The exact discussion which concluded with this amendment might be helpful as we go along; an excerpt from which is provided from The Madison Papers:

Mr. Pinckney opposed the vesting this power in the Legislature. Its proceedings were too slow. It would meet but once a year. The House of Representatives would be too numerous for such deliberations. The Senate would be the best depository, being more acquainted with foreign affairs, and most capable of proper resolutions. If the States are equally represented in the Senate, so as to give no advantage to the large States, the power will, notwithstanding, be safe, as the small have their all at stake in such cases as well as the large States. It would be singular for one authority to make war, and another peace.

Mr. Butler. The objections against the Legislature lie in a great degree against the Senate. He was for vesting the power in the President, who will have all the requisite qualities, and will not make war but when the nation will support it.

17. In Article \#9 of The Articles of Confederation and Perpetual Union it states that "The United States, in Congress assembled, shall have the sole and exclusive right and power of determining on peace and war." Merrill Jensen, The Articles of Confederation: An Interpretation of the Social-Constitutional History of the American Revolution 1774-1781 (Madison:University of Wisconsin Press, 1940), p. 266. 
Mr. Madison and Mr. Gerry moved to insert "declare," striking out "make,"war; leaving to the Executive the power to repel sudden attacks.

Mr. Sherman thought it stood very well. The Executive should be able to repel, and not to commence, war. "Make" is better than declare, the latter narrowing the power too much.

Mr. Gerry never expected to hear, in a republic, a motion to empower the Executive alone to declare war.

Mr. Ellsworth. There is a material difference between the cases of making war and making peace. It would be more easy to get out of war, than into it. War also is a simple and overt declaration, peace attended with intricate and secret negociaations(sic).

Mr. Mason was against giving the power of war to the Executive, because not safely to be trusted with it; or to the Senate, because not so constructed as to be entitled to it. He was for clogging, rather than facilitating war; but for facilitating peace. He preferred "declare" to "make." On the motion to insert "declare" in place of "make" it was agreed to. 18

This debate makes the point that only the Legislature was intended to commence or declare war. ${ }^{19}$ But, it still does not give a clear interpretation of what the delegates had in mind, thus a more in depth look at the discussion and debate occurring during this critical period of the Convention is in order. The available record of the debate indicates that the delegates may not have understood or did not want to understand the change supplied by Madison and

18. Hutchinson and Rachel, The Papers of James Madison, Vol. 4, 1 January $1782-31$ July 1782 , pp. 1351-1352.

19. "That it is the peculiar and exclusive province of Congress, when the nation is at peace to change that state into a state of war; whether from calculations of policy or from provocations, or injuries received; in other words, it belongs to Congress only, to go to war. But when a foreign nation declares or openly and avowedly makes war upon the United States, they are then by the very fact already at war, and any declaration on the part of Congress is nugatory; it is at least unnecessary." Corwin, The President: Office and Power 1787-1957, p. 199. 
Gerry even though this change seemed fairly clear and unambiguous. 20

The "ifs" must remain, for the records are confusing and unclear. The only certainty which emerged from the debate was that the wording was changed. It appears that there were four basic views which came out of this amendment, all influenced by Madison. First, the change broadened executive power by giving the executive the authority "to repel a sudden attack." Second, the original wording already having given such power to the executive, the change seemed to advance an undetermined power to the executive. Third, the change may have lessened the chance for involvment in war. Finally, the change removed the authority for Congress to have a role in the conduct of an established war no matter how it was initiated. ${ }^{21}$ These views do not, to my way of thinking, clear the picture of the framer's intent of the document.

Of these possibilities, the first two suggest an intention to broaden the executive's power in some vague way. The third assumption does not deal with the question of the day; that is, the qustion of the legislature versus the executive regarding this power. The fourth possibility suggests that the change referred to something other than the process of initially committing the nation

20. For example, Roger Sherman of Connecticut protested that the clause as originally reported, that is, without the Madison-Gerry amendment, "stood very well. The executive should be able to repel and not to commence war. Make better than declare the latter narrowing the power too much." It thus appears that Sherman believed that the original wording already left the executive free to repel sudden attacks and hence that in this respect the proposed change was worthless. But by narrowing the power of Congress, it was thought that the alternative would unduly broaden the executive's power in some other ways. Oliver Ellsworth, also of Connecticut, at first concurred with Sherman in opposing the change. Mason of Virginia, who did not trust the executive with the war power and did not feel that the Senate was constructed to be entitled to this power and who on that basis might well have agreed with Sherman and Ellsworth, instead supported the change. (Charles A. Lofgren, "War-Making Under the Constitution:The Original Understanding," The Yale Law Journal, Vol. 81 (March 1972), p. 676).

21. Graham, "Introuduction - Toward Jurisprudence of Peace," p. 15. 
to war. One important statement was made by Pierce Butler of South Carolina after the vote on the amendment had been recorded. As if to reinforce the conclusion that the change meant different things to different delegates, Butler moved to give the Legislature the "power of peace as they were to have of war." 22 It appears that the amendment had done little to change Mr. Butler's views. Earlier Butler had sided with his fellow Virginian, Charles Pinckney, in proposing that the Senate, rather than the entire Congress, have the war power.

It appears that we can not gain a clear understanding of the framers intention within the crucial area by looking only at the discussion of the war power; there are definitely other factors that may throw light on these intentions. Additional evidence may be gained by studying other deliberations at the Convention and the Constitution itself. Another important variable to consider here is the State debates which took place during the ratification process. The theories of war and reprisal which existed during this period might also be helpful. The consideration of English influence is also important, especially when we examine the doctrine of commander in chief.

Two months before the Madison-Gerry amendment surfaced, the Convention was concerning itself with the distribution of power, including that pertaining to powers of war. When the Randolph recommendations, as mentioned earlier, were proposed for use as guidelines for a Constitution, it suggested that the "National Legislature ought to be empowered to enjoy, among other things, the Legislative Rights vested in Congress by the Confederation." ${ }^{23} \mathrm{~A}$ fear of excessive executive power regarding war was very clear at this early session of

22. Lofgren, "War-Making Under the Constitution:The Original Understanding," p. 677.

23. Max Farrand, ed., The Records of the Federal Convention (Revised Edition; New Haven:Yale University, 1937), pp. 318-319. 
the Convention. Charles Pinckney cautioned that the powers of war and peace might properly be classed as executive power. James Wilson, a delegate from Pennsylvania, although in favor of the concept of a single magistrate as executive, took exception in that he was concerned about the overall power of such and worried about the analogy some might make to a king. Said Wilson, referring to the executive, "he did not consider the Prerogatives of the British Monarch, which included the power of making war, as a proper guide in defining Executive Powers. Some of these prerogatives were of a Legislative nature. Among others, that of war \& peace." 24

Little formal debate included the war powers question until the HamiltonGerry amendment was offered; thus it appears that the Convention took for granted the ideas which were proposed in the $R$ andolph recommendations. Drafts of proposed constitutions, which were forwarded out of the various committees for consideration, had no trouble allocating the war powers. From the start the Convention had little trouble in determining where this power should rest; it had been scarcely debated before the Hamilton-Gerry amendment and the logical conclusion was that the power of war-making fell almost automatically to Congress. An important consideration here is that the Convention was at the same time conferring on the executive, now denominated the President, the Commander in Chief title which gave him broad discretion over the armed forces. This particular title has been used as a formidable force in defending Presidential actions throughout the world. Again, the intent and interpretation of this clause must be looked at. It is interesting to note again that when the discussion on the war powers occurred, it took nearly a month of debate to bring the proposal to a vote, while the Commander in Chief clause

24. Lofgren, "War-Making Under the Constitution:The Original Understanding," pp. 678-679. 
passed unchanged and without recorded debate on August 27, 1787. This expeditious, unremarked assent suggests a narrow, non-controversial conception of the clause 25 , which seems to show that the real issue of the war powers debate was completed with the Madison-Gerry amendment and the Commander in Chief discussion was very secondary in the overall picture.

A move in September of 1787 appears to have sought to remove any remaining delegate doubt about the authority of Congress to authorize some form of undeclared hostilities. In this action, with the recommendation of Charles Pinckney, the Convention gave Congress the power to grant letters of marque and reprisal. Another clue that the Convention and its delegates understood where the power to make war was to be located can be seen in the actions of the Commitee on Style. The placement within the Constitution of a restriction on the states to wage war independently of the central government tends to put the war power in perspective. In Philadelphia, limitations even stricter than those which had appeared in the Articles of Confederation emerged during deliberation of the subject. These stipulations were included as separate coordinate articles in the draft. The Committee on Style, however, placed the prohibitions in the legislative article, where they appear in the final Constitution. ${ }^{26}$ The committee appears to have made this location decision by reason that any power of the states to wage war would take away from the power of the new Congress. From this, one might assume that the Committee on Style resolved something the whole of the Convention had been unable to; that the power of commencing war is properly a legislative function and no political entity may supersede it.

25. Ernest May, The Ultimate Decision:The President as Commander in Chief (New York:G. Braziller Press, 1960), pp. 3-19. (contd.)

26. "No state shall enter into any Treaty, Alliance, or Confederation; 
It is quite possible that in placing the restrictions on state war-making the committee was not concerned with the implications just discussed, yet my suspicion remains that something more than style prompted the committee's change, especially since the limitations could easily have been continued as one or more separate articles or placed in Article IV, which contains other provisions relating to the states. My contention is that the placement of the state warmaking restrictions contributed to a general, yet vague, impression that Congress was intended to be dominant in the field.

In considering state ratification of the Constitution it was clear that the state conventions were, much like the Philadelphia Convention, little concerned with how the new government would initiate war. Of all the proposed amendments to the Constitution which surfaced in the state conventions only one pertained to the war-making power and only in a superficial way. ${ }^{27}$ It may be

26. (contd.) grant Letters of Marque and Reprisal; coin Money; emit Bills of Credit; make any Thing but gold and silver coin a Tender in Payment of Debts; pass any Bill of Attainder, ex post facto Law, or Law impairing the Obligation of Contracts, or grant any Title of Nobility.

No State shall, without the Consent of the Congress, lay any Imports or Duties on Imports or Exports, except what may be absolutely necessary for executing its inspection Laws: and the net Produce of all Duties and Imports, laid by any State or Imports or Exports, shall be for the Use of the Treasury of the United States: and all such Laws shall be subject to the Revision and Control of the Congress.

No State shall, without the Consent of Congress, lay any Duty of Tonnage, Keep Troops, or Ships of War in time of Peace, enter into any Agreement or Compact with another State,or with a foreign Power, or engage in War, unless actually invaded, or in such imminent Danger as will not admit of delay." (Article I, Section 10, United States Constitution).

27. As an example, five of the eleven states which ratified the Constitution before the new government commenced operation offered amendments to it, but of the seventy-seven amendments thus proposed, only one, from New York and Rhode Island dealt with the power of Congress to declare. Moreover, that proposal, to require a two-thirds vote in each house of Congress for a declaration of war, was designed to protect state or regional interests rather than alter the balance of war-making power between Congress and the President. (Herman V. Ames, "Proposed Amendments to the Constitution, 17891889," Annual Report of the American Historical Association, Vol. 2 (1896), Pp. 269, 307-309). 
said that the provisions of the new Constitution regarding the power to make war received almost no attention, adverse or otherwise in the state debates. Nothing on record shows any disagreement within the state conventions regarding war powers as they were forwarded by the national convention, instead the records show harmony between state and national debate on the issue. For instance, in the Pennsylvania deliberation, declaring war and entering war were closely equated and any thoughts of an overzealous executive moving on his own were explicitly foreclosed. 28

At the same time supporters of this new document almost unanimously ascribed to the notion of the President as Commander in Chief in narrow terms. Most notably, Hamilton installed the President as Commander in Chief in a military sense but with no policy role. Hamilton writes in The Federalist Papers of this conception stating that the President's authority "would be nominally the same with that of the King of Great Britain, but in substance much inferior to it. It would amount to nothing more than the supreme command and direction of the military and naval forces, as first general and admiral of the confederacy; while that of the British King extends to the declaring of war, and to the raising and regulating of fleets and armies; all which by the constitution under consideration would appertain to the Legislature."29

28. James Wilson, speaking before the Pennsylvania convention stated that: "This new system will not hurry us into war; it is calculated to guard against it. It will not be in the power of a single man, or a single body of men, to involve us in such distress; for the important power of declaring war is vested in the legislature at large: this declaration must be made with the concurrence of the House of Representatives: from this circumstance we may draw a certain conclusion that nothing but our national interest can draw us into war." (Lofgren, "War-Making Under the Constitution: The Original Understanding," p. 685).

29. Gabriel, Hamilton, Madison and Jay on the Constitution: Selections from the Federalist papers, p. 149. 
When judged against future developments, Madison may have been wrong, at least to a degree, in giving a purely military function to the President's authority as Commander in Chief, but the evidence indicates that his view in this respect accorded well with that of his counterparts in the state debates.

Comments during the ratification period about the desirability of governmental energy, efficiency, and dispatch are sometimes taken to indicate an inherent power for the executive within the war making powers; however, in reality, the discussion of the times concerned itself mainly with the contention that the proposed national government's enhanced ability to raise armies and build fleets would promote national security and thus afford an effective deterrence to surprise attack on the United States ${ }^{30}$. Here one might offer the premise that the ratification conventions sought to provide national security without regard to a particular branch of government.

This concept may not mean Americans in the late 1780's rejected the idea that the President had responsibility to respond to sudden attack. Particularly in view of the common expectation that George Washington would be the first President, it is conceivable that they simply assumed there would be a presidential role in this regard. The overall conclusion of my research regarding this issue suggests that if the men of the day generally shared such an assumption, they still conceived of the President's war making role in exceptionally narrow terms.

It should also be noted that the United States was not the first nation which discussed the possibility of separating the war powers from the executive or, better put, allowing the legislative branch to have such an authority. John

30. Frederick W. Marks III, "A Winning Issue in the Campaign for Ratification of the United States Constitution," Political Science Quarterly, Vol. 86, No. 3 (1971), p. 444. 
Locke, the great theorist, suggested such an arrangement nearly one hundred years earlier, though England ignored his idea. He saw the same authority as properly exercising both powers, but his separation of them for purposes of analysis may have aided in establishing a basis for their later actual separation. ${ }^{31}$ A feeling seems to come from Locke's work that war making was a legislative function because it had to rest on the common understanding of the nation. This is not to say that Locke refused to recognize the role of an executive in this matter.

Before any conclusion can be reached regarding the intent of the framers of the new Constitution we should look briefly at the concept of the commander in chief which came out of the Philadelphia Convention.

The scope of the term commander in chief has been interpreted in many ways by many different people. Speaking before the Congress of the United States in 1971, Senator Barry Goldwater wondered aloud "just why the founding fathers saw fit to confer this title (commander in chief) on him and to invest him with these powers. I've never quite been able to understand; but I have a growing feeling that with the recognized and infinite wisdom of the founding fathers, they realized that a single man with these powers who would not be disturbed by the politics of the moment would use them more wisely than a Congress which is constantly looking toward the political results. Would it not be proper to assume, therefore, that the founding fathers in their wisdom foresaw the day when this situation might come about, and realizing that a Congress divided amongst different minority interests would be loath to give proper direction to a single American course, thought the power of war and peace might better be

31. J. W. Gough, ed., The Second Treatise of government, by John Locke, (Oxford: Basil Blackwell and Mott, 1946), p. 73. 
vested in a single man where the probability of minority weight might not have this effect." 32 a totally different interpretation was offered by another member of Congress recently. Senator Thomas Eagleton, in his book concerning war powers, stated that "we continue to require a commander in chief who can act expeditiously to repel sudden attack, but we require more than ever a responsible Congress to decide when national interests and commitments should lead to war." 33 Obviously their views differ.

The office of commander in chief has never carried with it the power of war and peace, nor was it invented by the framers of the Constitution. ${ }^{34}$ It was introduced into English political life over a century before the Constitutional Convention. It was used frequently in the seventeenth century throughout England when appointing commanders of various armies. The title has since been in common use in English government. The troops in each theater of action, as well as every fleet, have had a commander in chief. 35

On June 15, 1776, the Continental Congress unanimously chose George Washington as general. With this appointment his formal title became "General and Commander in Chief, of the army of the United States." ${ }^{36}$ This appointment instructed him to maintain strict discipline and to follow the Articles of War that were to be enacted to govern the forces, "and punctually to observe and follow such order and directions, from time to time, as you shall receive from

32. Congressional Record, (April 26, 1971), p. 117.

33. Eagleton, War and Presidential Power: A Chronicle on Congressional Surrender, p. 223.

34. Francis D. Wormuth, "The Nixon Theory of the War Power:A Critique," California Law Review, Vol. 60, No. 3 (May 1972), p. 630.

35. Ibid, P. 630 .

36. Jack N. Rakove, The Beginnings of National Politics: An Interpretive History of the Continental Congress (New York:Alfred A. Knopf, 1979), p. 73. 
this, or a future Congress of these United Colonies, or committee of Congress." 37

The use of the title commander in chief was not originally limited to the single person in charge of all armed forces in the land. There was no record of debate on the commander in chief clause in the Constitutional Convention. As mentioned earlier the clause passed with no controversy and leaving the impression that the title did not have significant authority within it.

Alexander Hamilton did not use the title when he offered his plan to the Convention on June 18, 1787. However, Hamilton implies early agreement with this title in his approval of the notes which James Madison took of his speech. These notes, which Hamilton read and approved, merely give "the supreme Executive authority to have the direction of war when authorized or begun." 38

With the many ambiguities above it is not surprising that one confronts a difficult problem when trying to gain a clear interpretation of the true meaning of the commander in chief clause. This clause should not be read as a significant independent, substantive power. The President's power as commander in chief, so heavily relied upon by modern presidents, should be read only as constituting the President, as the first general and admiral of the nation, and not an independent authority for making decisions that, in turn, require use of the armed forces to back them up.

Originally, it was only the military aspects of the commander in chief role that were stressed. This provision of the Constitution was interpreted as simply placing the President at the top of the pyramid of military command. The term commander in chief, as it came out of the Constitutional Convention and as

37. Ibid., pp. 195-196.

38. Wormuth, "The Nixon Theory of the War Power: A Critique," p. 633. 
ratified by the various state conventions, designated the officer who stood at the apex of a military hierarchy. In the British practice there were several such hierarchies, each with a separate commander in chief directly accountable to the Secretary of War. In the constitutional scheme there was a single hierarchy with a single commander in chief. But in all cases the commander in chief was under the direction of a political superior, a King or the Continental Congress; and after the Constitutional Convention, under a national Congress. The term carried absolutely no overtones of any independent political authority. In this position, the authority of the President as commander in chief to repel sudden attack or to prosecute a war after it is declared, is unchallenged; an intent of the framers which the drafting history of the Constitution makes clear.

The provision was devised so that the Congress, the chief executive, and the states would have a framework within which they could cooperate in the protection of the nation from external harm. Going to war was intended to be an orderly process in which deliberation would be given full play before conflict began and in which reason and caution would be used once hostilities had commenced. It was hoped that every effort would be made to prevent war through chance or mistake and that prudence and countervailing power would strengthen the forces of rationality.

The result was, as Madison said, "a partial mixture of power" 39 regarding this very important consideration (initiation of war). Madison went even further when considering these powers as stated in The Federalist Papers \#48. "It is equally evident, that none of them (branches of government) ought to possess,

39. Gabriel, Hamilton, Madison and Jay on the Constitution: Selections from the Federalist Papers, pp. 68-71. 
directly or indirectly, an overruling influence over the others, in the administration of their respective powers." ${ }^{40}$ In this area the two branches had interwoven responsibility and competing opportunity. Moreover, each had a clearly defined backdrop of authority from which to draw; the President through the executive power and the constitutional injunction that "he shall take Care that the Laws be faithfully executed," and the Congress through the constitutional authorization "to make all Laws which shall be necessary and proper for carrying into Execution all Powers vested by this Constitution in the Government of the United States."

The convention was never able to deal with the commander in chief clause in exacting terms. Three catagories of clarification did surface.

First, the founders drew a crucial distinction between offensive and defensive hostilities. If the United States were attacked, the commander in chief would repel the attack. In a certain sense, there is a built-in paradox in this school of thought. As W. Taylor Reveley has written, "speed and efficiency, on the one hand, and restraint upon executive prerogative, on the other, appear to have been the basic objective of the Drafters." 41 The Congress for its part in this defensive role would provide the President with a small army and navy so that he could fulfill his duty to put down insurrection. In addition, the Congress was authorized to establish procedures under which the President might nationalize state militia rapidly, so that he might respond effectively to the above mentioned attack.

40. Ibid., p. 72.

41. W. Taylor Reveley III, "Presidential War-Making: Constitutional Prerogative or Usurpation?," Virginia Law Review, Vol. 55, No. 7 (November 1969), p. 1282. 
Second, in cases where defensive action needed to be supplemented or replaced by offensive action, the concurrence of Congress would be required. There was little concern that time might be lost in the process. To the gathering at Philadelphia, the judgment of the entire nation, acting through its elected representatives, would have to be sought once the issue was no longer that of repelling attacking forces. ${ }^{42}$ Thus, whether simple reprisals or complex military operations or all-out war was in order, the Congress was to sanction these actions before they were started. Still, it seems that little attention was devoted to the precise extent of the executive's power to employ the armed forces for the purpose of protecting the nation. This particular area appears vague and ambiguous, the real intent of the framers is left unsaid.

A third vaguely stated intention of the framers of the Constitution, regarding the commander in chief, was the acknowledgement that the President would direct military operation. In other words, Congress would play no part in the day-to-day tactics. In his capacity as commander in chief, it was recognized that the President would "give orders and generally superintend the Army and Navy." 43 This, of course, was part of the thinking behind the Hamilton-Gerry amendment. This authority does not offer any connotations whatsoever regarding a war initiating power as residing within the executive branch of government.

These overall views by the framers were carried out of Philadelphia and into the debate at the state level during the ratification deliberation. For instance, in the North Carolina convention, James Iredell, who later became a

42. Eagleton, War and Presidential Power: A Chronicle on Congressional Surrender, p. 10.

43. Hearings before the House Committee on International Relations, "Background Information on the Use of U.S. Armed Forces in Foreign Countries, 1975 Revised," 94th Cong., 1st Sess., pp. 13-14 (1975). 
member of the Supreme Court, gave the same assurance when he stated that "I believe most of the governors of the different states have powers similar to those of the President. In almost every country, the executive has command of the military forces. From the nature of the thing, the command of armies ought to be delegated to one person only. The President, therefore, is to command the military forces of the United States, and this power I think a proper one; at the same time it will be found to be sufficiently guarded. A very material difference may be observed between this power, and the authority of the King of Great Britain under similar circumstances. The King of Great Britain is not only the Commander-in-chief of the land and naval forces, but has the power, in time of war, to raise fleets and armies. He also has the power to declare war. The President has not the power of declaring war by his own authority, nor that of raising fleets and armies. These powers are vested in other hands. The power of declaring war is expressly given to Congress, that is, to the two branches of the legislature. They have also expressly delegated to them the powers of raising and supporting armies, and maintaining a navy." 44

One additional limitation which the Constitution puts on the commander in chief is that with the start of hostilities congressional input does not necessarily cease. While Congress does not have a role in the tactical decisions made pursuant to the action, it does not surrender its wider policy prerogatives. At least, the changeover from defensive to offensive action would have to be sanctioned by the legislature. Similarly, decisions resulting in major changes in tactics, like changes which might bring new opponents into a war, would be an appropriate subject for congressional concern. A notion to keep in mind and within context here is that to command an army is to give it its orders, which 
means only that whatever orders are given must come through the commander not that he may give any orders he pleases, and the only orders which the commander may give to his armies are those which the law allows, and the laws are made not by him but by the Congress. To go beyond this standard would be for the commander to move above the legislative branch of government; in other words, would render the military the superior of the civil government.

The founding fathers were realistic enough to anticipate that a strongwilled President, exercising his power as commander in chief, might be reluctant to return to Congress for approval, or even consultation, once hostilities had begun. They were able to circumvent this possible source of friction by incorporating the funding clause into Article I, section 8. ${ }^{45}$ As Hamilton viewed the situation, the whole power of raising armies was lodged in the legislature subject to an important qualification which forbids the appropriation of money for the support of an army for any period longer than two years; a precaution which, upon close examination, sought a great and real security against the keeping of troops without evident necessity. ${ }^{46}$

It thus appears that the framers of the Constitution, having debated every contingency they could imagine, faced the possibility that Congress might someday be forced to deal with a strong and militant President whose course it might wish to deflect. They dealt with that possibility by giving Congress enough power to check a President whose military objectives went beyond or were contrary to those of the legislative branch. Evaluation of these powers were left to the courts.

45. "Congressional powers in foreign relations shall include the power to raise and support armies, but no appropriation of money to that use shall be for a longer term than two years," (Article I, section 8, United States Constitution).

46. Gabriel, Hamilton, Madison and Jay on the Constitution: Selections from the Federalist Papers, pp. 23-29. 
The Courts and the Question of War

The judicial precedents in the war powers area are fairly shallow. There are relatively few judicial decisions concerning the relationship between the Congress and the President in the exercise of their respective war powers under the Constitution. Only too often the courts have regarded the subject as a political question and refused to take jurisdiction. 47 For example, in Luftig v. McNamara, the District of Columbia Court of Appeals upheld the dismissal of a suit by an Army private to enjoin the Secretary of Defense from sending him to Vietnam on the ground that the war was unconstitutional. ${ }^{48}$ The federal court in fact refused to determine the constitutionality of a specific military conflict such as Vietnam.

The political question doctrine simply means that the courts refuse to act because the judiciary has decided that a particular issue is better handled by, or constitutionally required to be handled by, another branch of government. Some might say the political question doctrine is a constitutional check on the capacity of the judiciary to decide a given issue, yet many claim it is a very effective means for the courts to escape from passing judgment on an issue which might undermine the Court's power. It is felt by this writer that invoking the political question doctrine in the Luftig case ultimately erodes the basis of the Court's authority in any future cases regarding this issue.

47. William P. Rogers, "Congress, the President, and the War Powers," California Law Review, Vol, 59, No. 1 (Januray 1971), Pp. 1203-1204.

48. The court stated: "It is difficult to think of an area less suited for judicial action than that into which appellant would have us intrude. The fundamental division of authority and power established by the Constitution precludes judges from overseeing the conduct of foreign policy or the use and dispostion of military power; these matters are plainly the exclusive province of Congress and the executive," Luftig v. McNamara, 373 F. 2d 664, pp. 665-666, (D.C. Cir. 1967). 
In assessing this judicial role, it is crucial to keep in mind exactly what the question is. It is not whether or not the United States is to fight a war, but rather the branch of government which has the power to declare such. I would be the first to agree that whether this country is to fight a war is a political question; but which branch has the power to decide whether to fight or not is a question for the judicial branch to determine.

There is a clear distinction between the question of whether a court can decide which branch of government is entrusted with responsibility for a particular political decision such as whether to fight a war, and the question of whether courts are to participate in making the political decision itself. Since the first of these questions involves nothing more than a constitutional interpretation of the most basic type, no problem of justiciability should arise. Justiciability should become a consideration only when a court is asked to pass upon the second question, that is, to pass upon the correctness of a political decision made by a coordinate branch of government to which the decision has been committed by the Constitution.

The proposition that a court may not rule on the issue of whether the President must seek a congressional declaration as a prerequisite to engaging in war whether for the reason that the question is political or for any other reason, is at best dubious, since it denies the court the power to delineate the authority of the various branches of government. Since Mabury v. Madison, it has been clear that this power is a major part of the court's role in the constitutional scheme. $^{49}$

49. Schlesinger, The Imperial Presidency, p. 271. 
That the issue is justiciable is graphically demonstrated by past cases. The courts have pronounced upon it on more than twenty occasions, ranging from the earliest days of this country's existence to its recent history. ${ }^{50}$ Examples of said cases are "United States v. Macintosh (1930); The Prize Cases (1862); Talbot v. Seeman (1801); National Saving and Trust Co. v. Brownell (1955); Savage v. Sun Life Assurance Co. (1944); West v. Palmetto State Life Insurance Co. (1943); and Western Reserve Life Insurance Co. v. Meadows (1953). In fact, only in Luftig v. McNamara is there an example of the court refusing to act, at least by implication, in such a way that the question of which branch of government has the power to declare war is a political question rather than a justiciable one. Some of these cases are United States Supreme Court decisions, some are lower federal court cases, and some are state supreme court opinions. Some involved the legality of military acts committed by the United States or its citizens, some involved the power to draft men, and some involved insurance recoveries dependent upon which branch has the power to declare war. When so many courts, over so long a period and in so many cases of action, have ruled on the question of which branch has the power to declare war, then it is clear that this question cannot be a political one, but must be a judicial one.

The courts, as various as they may be, have seemingly without notice set up certain factors which they have found useful in determining cases which are related to this question. One such factor is whether there are judicially discoverable and manageable standards for resolving the question. Once the proper question is asked, as explained above, it is visible that there are judicial standards which are eminently clear, manageable, and constitutionally ordained.

50. Lawrence R. Velvel, "The War in Vietnam: Unconstitutional, Justiciable, and Jurisdictionally Attackable," Kansas Law Review, Vol. 16, (1968), p. 480. 
These standards are that, under the language of the American Constitution, the Congress and not the executive has the power to declare war.

A very important factor to also be considered here is the idea of respect between the various branches of government. In 1962 the Supreme Court held in Baker v. Carr, that when considering justiciability of an issue a decision must not be formalized which might show a quality of disrespect by one branch toward another. 51 A judicial decision that Congress has the power to declare war expresses no disrespect for another branch. On the contrary, it expresses respect both for the power of the Congress and the endurability of the Constitution. It cannot be argued that such a decision would express disrespect for the executive. If that were true, then disrespect for the executive has been expressed by every court which has ever said that the Congress has the power to declare war, not to mention every decision which has ever struck down executive usurpation of power and the very clause of the Constitution which gives Congress the power to declare war. Such conclusions are absurd.

Another element which comes to play in this question of justiciability is whether a decision made by one branch of government at the expense of another branch is to be considered final. Again, here the courts have an obligation to act. This question was raised in Baker v. Carr. There is no need to give finality to an executive decision of the nature we are considering. For the courts to allow such a usurpation to stand is allowing for the Constitution to be nullified. Directly contrary to the Constitution, the most important decision which a nation can make, whether to initiate war, will be in the hands not of the

51. In 1962 the high court offered a series of tests by which political questions could be identified. In his opinion in Baker v. Carr, Justice Brennan said the court should not intervene if its intervention expressed disrespect for other branches of government, Baker v. Carr, 369 U.S. 186, 211, 217, 226 (1972). 
Congress, but of a small group of men. And, if the executive can usurp the most important decision a nation can make, what is to stop him from usurping lesser powers to the point of total domination of government?

Finally, if allegations of the need for finality and avoidance of disrespect did not turn Baker into a political question, then the overall question of war power and who has it shouldn't either. Baker said that another criterion for judging the nonjusticiability of a question is whether a decision might express disrespect within the various branches of government. However, as shown above, for the courts to study the issue of the separation of power and come to some conclusion is following the guidelines of the Constitution. To reiterate, courts have many times pronounced on this questions, there are clear criteria, the question is not committed to another branch, no disrespect would be shown another branch, and there is every need not to accord finality to the executive's decision that it can usurp the power to declare war. In conclusion, it is the function of courts not only to maintain the separation of powers by striking down usurpation of power, but to safeguard and insure a free political process and representative government. Courts should perform this function in regard to the power to declare war: they should insure that this power remains with the people's legislative representatives to be exercised through the political process of Congress. The judicial branch must function to guarantee that no man or small group of men can circumvent constitutional government by arrogating unto themselves the power to declare war.

As previously indicated, the breadth of judicial decisions dealing with the presidential-congressional war powers relationship are shallow, but it is certainly not non-existent. 
One of the early cases which should shed some light on where the courts intend the power to reside may be seen in the Little v. Barreme case of $1804 .^{52}$ Briefly, the Non-Intercourse Act of 1799 authorized the seizure, by the Navy, of American vessels en route to French ports. In issuing orders to the Navy, President Adams extended this to include vessels outgoing from French ports, and a Captain Little thereupon captured a brigantine that had just left a Franch port in the West Indies. When the owner of the cargo complained, the Supreme Court found that the seizure was unlawful even though ordered by the President. If Congress had been silent, Chief Justice Marshall said, in his opinion, the President's authority as commander in chief would have sufficed. But once Congress had "prescribed the manner in which this law shall be carried into execution," $" 53$ the commander in chief was obliged to respect the limitations imposed by Congress. Since the President's instructions collided with the act of the Congress, the court held them to be illegal, and could neither justify the seizure nor excuse Captain Little from damages, which he was ordered to pay at the sum of $\$ 8,504$. 54

Another case, which is more often cited regarding the President's military powers is The Prize Cases of $1862 .{ }^{55}$ The Prize Cases upheld the action of President Lincoln in declaring, as a war measure, a blockade of ports in Southern states that had seceded from the Union. The court held that the President had

52. Francis D. Wormuth, "The Vietnam War: The President versus the Constitution," in The Vietnam War and International Law, Vol II, ed. by Richard A. Falk (New Jersey: Princeton University Press, 1969), p. 782.

53. Schlesinger, The Imperial Presidency, p. 62. p. 782.

54. Wormuth, "The Vietnam War: The President versus the Constitution," 55. 2 Black (67 U.S.) 635 (1863). 
this power through the "whole executive power that the Constitution conferred on him." 56 Clainants whose ships had been seized during the first weeks of the blockade contended that under international law a blockade was legal only in a state of war. Since there had been no declaration of war, Lincoln's blockade was illegal, at least until Congress sanctioned it by legislation in July 1861.

A majority of the court upheld Lincoln's action ( 5 to 4 ). They did so, however, on narrow grounds. No attempt was made to justify Lincoln's theory that the law of necessity made otherwise unconstitutional acts constitutional. ${ }^{57}$ The court simply felt that the insurrection had created a war of fact and the President was forced into responding in a manner best appropriate to the situation. The dissenting justices claimed that only Congress could determine whether war existed or should be declared. However, what Lincoln called the "public necessity," supported the majority decision. Schlesinger seems to put the issue in a very clear light when he states that "under indisputable crisis, temporary despotism was compatible with abiding democracy." 58 An important point to keep in mind when considering The Prize Cases is that the action taken by Lincoln was totally domestic in nature and was pursued during a most desperate national emergency.

Since the majority in The Prize Cases confined its endorsement of the war power to the circumstances of ongoing domestic insurrection, it is hard to see, as later commentators have claimed, that the decision conferred special authority on Presidents in peacetime or in relation to foreign wars. Lincoln himself

56. Paul G. Kauper, "The Steel Seizure Case: Congress, the President and the Supreme Court," Michigan Law Review, Vol. 51, No. 2 (December 1952), p. 145.

57. Schlesinger, The Imperial Presidency, p. 64.

58. Ibid., p. 65. 
questioned the constitutionality of some of his wartime actions; however, his phraseology also included statements which implied that the very life of the nation was at stake and under such situations the President might be compelled to take drastic actions.

The classic case regarding much of the presidential prerogative claimed in recent years comes from the United States v. Curtiss-Wright Export Corporation. This case, which was heard by the court in 1936, enunciated the role of the President as the representative of the nation in foreign relations. It further fashioned the concept of "inherent presidential powers," something of long standing but without previous title. Raoul Berger lays much of the blame for recent presidential expansionism to some ill-considered dicta in the CurtissWright case, ${ }^{59}$ especially on the part of Justice Sutherland. Despite searching criticism, Curtiss-Wright has become the foundation of subsequent decisions and has all too frequently been cited for an omnipresent presidential power over all aspects of foreign relations.

The case proceeded from a Joint Resolution which authorized the President, upon making certain findings and engaging in consultations with other American Republics, to declare unlawful the sale of munitions to countries then engaged in armed conflict in the Chaco, namely Bolivia and Paraguay, if it might help in the reestablishment of peace within the area. The sole issue was whether this was an improper delegation of power to the executive, but the aims of Justice Sutherland soared far beyond this modest goal. Justice Sutherland sought to establish that in the realm of external affairs "the President alone has the power to speak as a representative of the nation." 60

59. Raoul Berger, "The Presidential Monopoly of Foreign Relations," Michigan Law Review, Vol. 71, No. 1 (November 1972), p. 26.

60. United States v. Curtiss-Wright Export Corp., 299 U.S. 304, 319 
In disposing of the contention that the statute was unconstitutional as an invalid delegation of legislative power to the President, the court declared that this ground of attack was irrelevant in the field of foreign affairs where the federal government's authority to act was an inherent commitment and not derived by delegation from the Constitution and an area where the President by virtue of his office enjoyed a plenary and exclusive power "as the sole organ of the federal government," within the field.

The Curtiss-Wright Corporation probably went into the case feeling somewhat confident, especially after a district court had viewed their case favorably before the government appeal. The court in 1936 was understood to favor property against government and to question congressional delegation of power to the executive ${ }^{61}$, but always within the realm of domestic affairs. This case involved foreign affairs. Two justices in particular had vast experience in the foreign affairs area: first, there was Justice Charles Evans Hughes, a former Secretary of State; and second, Justice George Sutherland, a former member of the Senate Committee on Foreign Relations, who did, of course, write the opinion for the court. Justice Sutherland was keenly aware of the differences between external and internal policy. The two classes of power had been considered by Sutherland nearly twenty years earlier when he wrote his Constitutional Power and World Affairs. ${ }^{62}$ He saw these powers as different both in origin and in nature.

In writing for the majority in the Curtiss-Wright case he stated that "not only, as we have shown, is the Federal power over external affairs in origin and

61. Schlesinger, The Imperial Presidency, p. 101.

62. George Sutherland, Constitutional Power and World Affairs (Princeton: Princeton University Press, 1913), P. 86. 
essential character different from that over internal affairs, but participation in the exercise of the power is significantly limited. In this vast external realm, with its important, complicated, delicate, and manifold problems, the President alone has the power to speak or listen as a representative of the Nation." ${ }^{63}$ Thus it became the court's opinion, through Sutherland, that the idea of an executive exercising only the powers which are enumerated in the Constitution pertained to internal affairs only. External sovereignty did not rest on the affirmative grants of the Constitution. Sutherland held that this power pre-dated the Constitution.

The inherent authority of the President in foreign affairs, the court continued, included the notion that the President, not Congress, was in a position of knowing the conditions which prevail in foreign countries. The court saw the necessity of secrecy of information and established that the Congress could not demand information from the President when premature disclosure might harm the environment of international affairs.

Finally, the decision gave the President a degree of discretion and freedom from statutory restriction which the Constitution did not. Something John Marshall had given the president one hundred and thirty-seven years earlier with his famed "sole organ" statement. It gave the President something that the courts had been reluctant to do in domestic affairs: it provided the existence of an inherent, independent, and superior presidential power, not derived from the Constitution and not requiring legislation as the basis for its exercise.

What is interesting about the decision is that it came from a court that seemed very much anti-presidential, yet the decision had only one member on

63. Hearings before the House Committee on International Relations, "Background Information on the Use of U.S. Armed Forces in Foreign Countries 1975 Revised," 94th Cong., 1st Sess., p. 9 (1975). 
the dissenting side. This seemingly anti-presidential court thus provided one of the most extreme extensions which could be accorded to the power of the President in international relations.

The language of this case goes to the extreme in formulation of a constitutional theory to support the claim of presidential prerogative where the conduct of foreign affairs is concerned, particularly so since it rests upon a conceptions of inherent rather than delegated power. It is important to note that much of the language of the case can be rejected as dictum since Congress had delegated authority to the President to deal with the problem, so that the result of the case could easily have been justified either on a theory of executive authority concurrent with, and subject to, the paramount power of Congress to regulate foreign commerce, or on a simple theory of delegation of legislative power by Congress. To the contrary, future generations of executives have not seen the decision within this light.

Finally, in Youngstown Sheet \& Tube Co. v. Sawyer, limits to the commander in chief doctrine were clearly spelled out by the court as action by the executive was reversed.

In Youngstown the court confronted an executive who was exercising power in the face of congressional opposition. During the Korean War President Truman, in order to avert a nation-wide steel strike feared to be disruptive to the war effort, had ordered the steel plants be seized by the government. Congress, however, had sought to resolve problems such as this when it passed the Taft-Hartley Act of $1947^{64}$, substituting instead an eighty-day national emergency injunction option which could be used as a cooling off period. Truman

64. Kauper, "The Steel Seizure Case: Congress, the President and the Supreme Court," p. 151. 
defended his actions through application of the commander in chief clause of the Constitution, as well as interpreting that the Taft-Hartley Act did not and could not preclude the President's emergency action in this case. At a press conference shortly thereafter, the President was asked, if it was legal for him to seize the steel industry, was it legal to seize the media of the nation? In response Mr. Truman concluded that under similar circumstances the President had to do whatever he believed best for the country. While the President did not elaborate, the White House added that the President's point was that he had power in an emergency, to take over "any portion of the business community acting to jeopardize all the people." 65

A very colorful dissenting opinion, written by Chief Justice Vinson, sought to invent a clause which would even supersede the theory of inherent power discussed in the Curtiss-Wright case. While the Constitution required that Congress pass all laws necessary and proper for carrying into effect its delegated powers, the dissenting opinion in the Youngstown case could have the President pass all laws necessary and proper for carrying into effect policies endorsed by Congress. The Vinson opinion further tried to cover up the magnitude of this claim by saying that the President had acted during a time of extreme emergency and had then referred the question to Congress. ${ }^{66}$ But Congress, which alone had the power to pass emergency legislation, had not acted. What the Vinson opinion called an emergency was simply the failure of Congress to share the President's opinion as to the need for and the propriety of plant seizure.

65. "Could Seize Press, President Implies," The New York Times, April 18,1952, p.13.

66. Kauper, "The Steel Seizure Case: Congress, the President and the Supreme Court, " pp. 171-174. 
The majority (6-3) opinion included Justice Frankfurter, Justice Black, Justice Jackson and Justice Douglas. The strongest brief was credited to Justice Jackson as he discussed not only the President's role as commander in chief, but also took aid at the dissenting opinion with a ringing interpretation of the separation of powers between the Congress and the executive branches of government. On the practical aspects of the sharing of power between Congress and the President Jackson wrote:

The actual art of governing under our Constitution does not and cannot conform to judicial definitions of power of any of its branches based on isolated clauses or even single Articles torn from context. While the Constitution diffuses power the better to secure liberty, it also contemplates that practice will integrate the dispersed powers into a workable government. It enjoins upon its branches separateness but interdependence, autonomy but reciprocity. Presidential powers are not fixed but fluctuate, depending upon their disjunction or conjunction with practical situations in which a President may doubt, or others may challenge, his powers, and by distinguishing roughly the legal consequence of this factor of relativity.

1. When the President acts pursuant to an expressed or implied authorization of Congress, his authority is at its maximum, for it includes all that he possesses in his own right plus all that Congress can delegate. In these circumstances, and in these only, may he be said (for what it may be worth) to personify the federal sovereignty. If his act is held unconstitutional under these circumstances, it usually means that the Federal Government as an undivided whole lacks power.

2. When the President acts in absence of either congressional grant or denial of authority, he can only rely upon his own independent powers, but there is a zone of twilight in which he and Congress may have concurrent authority, or in which its distribution is uncertain. Therefore, congressional inertia, indifference or quiescence may sometimes, at least as a practical matter, enable, if not invite, measures on independent presidential responsibility. In this area, any actual test of power is likely to depend on the imperatives of events and contemporary imponderables rather than on abstract theories of law. 
3. When the President takes measures incompatible with the expressed or implied will of Congress, his power is at its lowest ebb, for then he can rely only upon his own constitutional powers minus any constitutional powers of Congress over the matter. Courts can sustain exclusive presidential control in such only by disabling the Congress from acting upon the subject. Presidential claim to a power at once so conclusive and preclusive must be scrutinized with caution, for what is at stake is the equilibrium established by our constitutional system. 67

From here Justice Jackson moved into the conception of the commanderin-chief which was used extensively by the White House as justification for the steel seizure. Jackson stressed that above all we must be constantly reminded that the President, while commander in chief, is also always a civilian. Justice Jackson expanded upon the significance of this provision in these words:

There are indications that the Constitution did not contemplate that the title Commander-in-Chief of the Army and Navy will constitute him also Commander-in-Chief of the country, its industries and its inhabitants. He has no monopoly of "war powers," whatever they are. His command power is not such an absolute as might be implied from that office in a militaristic system but is subject to limitations consistent with a constitutional Republic whose law and policymaking branch is a representative of Congress. The purpose of lodging dual titles in one man was to insure that the civilian would control the military, not to enable the military to subordinate the presidential office. No penance would ever expiate the sin against free government of holding that a President can escape control of executive powers by law through assuming his military role. 68

Then returning to the more specific case which the court faced, Justice Jackson concluded his opinion in these words:

67. Hearings before the House Committee on International Relations, "Background Information on the Use of U.S. Armed Forces in Foreign Countries 1975 Revised, " 94th Cong., 1st Sess., P. 11 (1975).

68. Ibid., p. 12. 
What the power of command may include I do not try to envision, but I think it is not a military prerogative, without support of law, to seize persons or property because they are important or even essential for the military and naval establishment. 69

Justices Jackson, Burton and Douglas attacked the dissenting opinion regarding the emergency power. For instance, while Justice Douglas agreed that there had been an emergency he continued that while it was necessary that measures be taken to keep steel in production that "does not mean that the President, rather than Congress had the constitutional authority to act." 70 Justice Burton argued that the Constitution gave the right to deal with national emergency strikes to the Congress through it's power of emergency legislation. Burton went to some length to discuss this particular issue within the case stating that:

Does the President, in such a situation, have inherent constitutional power to seize private property which makes congressional action in relation thereto unnecessary? We find no such power available to him under the present circumstances. The present situation is not comparable to that of an imminent invasion or threatened attack. We do not face the issue of what might be the President's constitutional power to meet such catastrophic situations. Nor is it claimed that the current seizure is in the nature of a military command addressed by the President, as Commander-in-Chief, to a mobilized nation waging, or imminently threated with, total war. 71

Through the opinions expressed here it is easy to see what the court had in mind when discussing Youngstown. The Supreme Court concluded that the powers of the President, both as commander in chief and in his executive capacity, were not unlimited and could be restrained by another branch of the

69. Ibid., p. 12.

70. Kauper, "The Steel Seizure Case: Congress, the President and the Supreme Court," p. 163.

71. Wormuth, "The Nixon Theory of the War Power: A Critique," p. 674. 
government. All the justices in the majority indicated that the extent to which Congress had acted to control the action taken by the President was significant in determining the constitutionality of his action. The opinions imply that "when Congress speaks on the question of what form executive action may take, such power to act alone as the President may have will be circumscribed." 72

Finally, in the Steel Seizure Case, the justices may have disagreed on the proper interpretation of Congress' failure to act on relevant legislation; however, it is clear that they were in general agreement (majority view) that, if Congress enacts a clear prohibition on military action in specified areas (strike breaking for instance), presidential power would be effectively limited.

There are many more cases which one could use to discuss the role of the Supreme Court and the judicial system as a whole when concerned with the issue of the roles of Congress and the executive in war powers. A look at the New York Times v. The United States, which was concerned with the so-called Pentagon Papers might be helpful. Or an examination of the United States v. Macintosh might have been beneficial, in which the court reaffirmed Congress' absolute authority to declare war. It might be added here that in the Macintosh case the court also afforded the Congress the plenary power to wage war. ${ }^{73}$

72. Alexander Bickel, et al., "Indochina" The Constitutional Crisis," memorandum by Yale Law School, printed in the daily edition of the Congressional Record (Senate), pp. 15409-15416 (May 13, 1970).

73. In U.S. v. Macintosh, The Supreme Court stated, "The Constitution wisely contemplating the ever-present possibility of war, declares that one of its purposes is to provide for the common defense. In express terms Congress is empowered to declare war, which necessarily connotes the plenary power to wage war with all the force necessary to make it effective; and to raise armies, which necessarily connotes the like power to say who shall serve in them and in what way," 283 U.S. 605, 622 (1931). 
The courts of the United States have laid down many different verbal formulations when considering the war powers issue. In the four cases reviewed above, one might consider the issue as a stalemate. Two cases stressed the presidential action theory while two sought to limit executive action, especially if such action was at the expense of the legislative branch of government.

Even with these generalities in the attitudes of the court regarding the separation of powers concerning war powers, the courts seem to serve more to enlarge the presidential prerogative over initiation of war than to restrain it. Rather than rule on this controversial, issue the courts have usually hidden behind the "political question" doctrine. Fear of noncompliance should not be a factor. A judicial command affecting the use of force abroad would be obeyed by the executive branch, although perhaps not without great political cost to the court and great stress upon our constitutional system. ${ }^{74}$

No Supreme Court decision has restrained the conduct of presidentialauthorized hostilities. There have been numerous opinions which have toyed with the issue, but none have actually grabbed the problem by the horns and come up with any concrete results. Of the cases that I have reviewed, only the Youngstown case actually changed the presidential policy; however, presidential power to authorize hostilities was not an issue and the court did not doubt its capacity to appraise the constitutional basis for the nonmilitary presidential order, interpret the relevant statutes, and administer a return to private control. ${ }^{75}$

74. Reveley, "Presidential War-Making: Constitutional Prerogative or Usurpation?," p. 1277.

75. Leonard G. Ratner, "The Coordinated Warmaking Power -Legislative, Executive, and Judicial Roles, "Southern California Law Review, Vol. 44, (1971), p. 487. 
With the close of the tragedy of Vietnam, hopefully the question of future presidential authorization of war will not surface; however, it is ironic indeed that America must be killing human beings before the issue can be considered.

The Supreme Court is a "court of last resort presumptively" ${ }^{76}$ and should thus consider an issue only when all other avenues have failed. The controversy of the war powers is not a new situation and little has been accomplished between the contending sides in efforts to solve the problem. There appears to be a clear line of defiance on the part of the executive in this area. The Constitution is quite clear as to which branch may initiate war; it is now up to the court system to put these constitutional interpretations into practice. In over two hundred years they have been circumvented by the executive branch of government at the expense and with the silent support of the legislative branch of government.

The Evolution of the Power to Make War

Legal interpretations and study of the intent of the founding fathers are but two elements to consider in this puzzle. Another important factor which must be reviewed is the historical application of the powers in question.

76. Alexander M. Bickel, The Least Dangerous Branch: The Supreme Court at the Bar of Politics (Indianapolis: Bobbs-Merrill Press, 1962), p. 258. 
Some years ago Senator Barry Goldwater, writing in the Arizona State University Law Journal, and considering the question of executive initiative in the use of military force, concluded that this phenomenon was anything but a new concept. He further cited 197 cases of American military action and stated that "only five of which have been declared wars." 77 (The list of military actions has been updated by my research to 224. Listings are located in Appendix I).

In considering Senator Goldwater's statement and looking at the early dates of the various conflicts the assumption must be that from the beginning of our constitutional history, Presidents have both deployed the armed forces abroad and committed them to actual hostilities without explicit congressional authorization and in direct contradiction to the Constitution. Such action can be traced to the country's first administration. During the campaign against the Indians in 1794 President Washington acted in a manner beyond his scope as executive. In this conflict the Indians had decided at one point to take a stand at a British fort located twenty miles within American territory. While technically the existence of a foreign fort within the territory of the United States would be considered an act of aggression, the British made no moves which would indicate they intended aggression. Though anxious to avoid a new war with the English which might arise if they supported the Indians against an American attack Washington dispatched instruction to the American commander which left little doubt of his confidence that he possessed the power to begin such a conflict if necessary. The situation was never to reach that point. ${ }^{78}$

77. Barry M. Goldwater, "The President's Ability to Protect America's Freedom - The Warmaking War," Arizona State University Law Journal, Vol. 1971 , No. 3 (1971), Pp. 424-425.

78. "Congress, the President, and the Power to Commit Forces to Combat," Harvard Law Review, Vol. 81, No. 8 (June 1968), Pp. 1789-1801. 
While Washington seemed ready to overstep his authority, Thomas Jefferson, who followed Washington into the White House by just four years, was quick to acknowledge the congressional right to license hostilities. After an American naval schooner was fired on by a Tripolitanian cruiser in the Mediterranean and after the schooner had successfully repulsed the attack, Jefferson brought the question before Congress. Jefferson stated that the commander was unauthorized by the Constitution to go beyond the line of defense in the action. Further, Jefferson made clear that since the commander of the schooner did not have that authority he was forced to release the vessel and its crew, once it was "disabled from committing further hostilities." 79

It appears clear from these two very brief cases of presidential initiated war that the particular executives involved, while commencing the conflict, also continued to realize where the authority lay. It also seems clear that the idea of the conflict between the Congress and the President over the war powers did not start with any particular administration, as many commentators have suggested, but rather was a part of the history of this nation from the Constitutional Convention to the point of crisis which exists today. There appear to be stages in which this imbalance of power first was born, then accelerated, and hopefully finally will come back into line. The last stage is occurring today and I doubt that the War Powers Resolution is the last word to be struck on the subject.

The first period to consider in the process which takes us to today's heavy imbalance within this delicate structure of war making can be traced from the Philadelphia Convention to approximately the end of the nineteenth century. This era might be characterized as a time of collaboration between the two branches of government. Most of the actions listed in Appendix I occurred

79. Schlesinger, The Imperial Presidency, p. 22. 
during this period. Events such as the First Barbary War of $1801-1805$, the Perry Expedition to "Open Japan" in 1853 and 1854, and numerous incursions into China are prime examples. The use of this period as a show of precedents for the justification of recent actions may, however, have serious flaws. ${ }^{80}$ Most of these actions were minor undertakings, designed to protect American citizens or property, or to revenge a slight to national honor, and most involved no combat, or even the likelihood, with the forces of another state. Executives of this period were generally reluctant to undertake military operations abroad without congressional approval.

While there were actions during this period unauthorized by the Constitution they remained small in scope and none appeared to be presidential attempts at expanding the war power of the executive office. The era in question does include three formally declared wars. Each should be examined so as to clarify which branch of the government initiated the war. First, the

80. The State Department, in its defense of Vietnam action stated in 1966: Since the Constitution was adopted there have been at least 125 instances in which the President has ordered the armed forces to take action or maintain positions abroad without obtaining prior congressional authorization, starting with the undeclared war with France (1798-1800). Further, the department said that the Constitution leaves to the President the judgement to determine whether the circumstances of a particular armed attack are so urgent and the potential consequences so threatening to the security of the United States that he should act without formally consulting the Congress. (Leonard Meeker, "The Legality of United States Participation in the Defense of Vietnam," Department of State Bulletin No. 54 (1966), Pp. 474, 484-485). 
decision to enter the War of 1812 was made by Congress after extended debate. $^{81}$ Schlesinger describes this debate and remarks by Madison as representing a "suitable exercise of concurrent authority." 82 Madison did not offer kind words for England in a message to Congress in June of 1812; however, the primary impetus to battle seems to have come from what Richard Leopold calls a group of "war hawks" 83 in the legislature. Similarly, McKinley was pushed into war with Spain in 1898 by congressional and popular fervor; however, his sending of the battleship Maine to Havana and its subsequent sinking tended to fire up the passion of not only the Congress but the nation as a whole. Full congressional authorization was given before the initiation of hostilities. Congress first passed a joint resolution authorizing the President to use armed force if necessary to insure Cuban independence and Spanish withdrawl from the island and then followed with a formal declaration of war when Spain recalled its ambassador from Washington and showed no sign of leaving the island. This resolution gives one an eerie feeling when the action of the Congress in the summer of 1964 is considered. The events in the Gulf of Tonkin seem strangely similar.

The war which this country had with Mexico in 1846 was much different from the later war with Spain. In the Mexican conflict, Congress was presented with what amounted to a presidential "fait accompli" by President James Polk.

81. Reveley, "Presidential War-Making: Constitutional Prerogative or Usurpation?," p. 1259.

82. Schlesinger, The Imperial Presidency, p. 26.

83. Richard W. Leopold, The Growth of American Foreign Policy: A History (New York:Alfred A. Knopf, 1962), pp. 62-64. 
Polk provoked the Mexicans into a conflict which the legislators felt compelled to support. Polk then proceeded to paint the facts of General Taylor's advances into Mexico in such a way that the legislators could only approve the action. This action by Polk was the only instance, except for the last decade of the 19th century, in which the executive sought to encroach upon the legislature's constitutional prerogative by the manner in which he deployed American forces. Polk may not be the only President in history who, by needlessly deploying the armed forces, provoked an attack by a potential enemy.

There are two interesting points about this issue which W. Taylor Reveley brings out in his article on the presidential war powers. Mr. Reveley contends that since the Congress was not outspoken about General Taylor's exploits into the disputed territory they may have been acquiescencing through silence. (This silent acquiescence was used by many pro-Vietnam people during the 60 's and early 70's.) The other important point that Reveley brings up regards congressional attempts to regain the power which Polk applied during the war. Within two years, the House of Representatives censured Polk for his part in the initiation of the conflict. ${ }^{84}$ By a vote of $85-81$ on January 3,1848 , the House resolved that the war had been "unnecessarily and unconstitutionally begun by the President of the United States." 85 The effects of this move by Congress may have been directed at General Taylor as well, who was then running for President himself. Irregardless, the war was concluded by a treaty a few months later.

84. Reveley, "Presidential War-Making: Constitutional Prerogative or Usurpation?," p. 1260. p. 726.

85. Wormuth, "The Vietnam War: The President versus the Constitution," 
This legislation by the Congress seems to make one thing exceptionally clear regarding this situation. This vote of censure demonstrates the understanding of the Congress, in compliance with the Constitution, that the President has no right to initiate war. And it makes it clear that when the President obliges the Congress to declare war, as was the case here, this ratification does not free him from blame for his illegal act. Acceptance by Congress of the territorial gains out of this war in the Treaty of Guadalupe Hidalgo does not remove blame for initiation.

The second stage in the evolution of the authority over the war powers began at the turn of the century and continued into World War I. Close collaboration between the executive and Congress became the exception, as did presidential deference to congressional views on the use of force abroad. Reveley points out, however, that the Congress was still a very strong force at this time in the shaping of foreign policy. Regardless of the validity of this view, the growth of American military power enhanced the ability of the President to employ the armed forces without prior congressional approval.

What was important as the United States entered the 20th century was its views of the environment around it. The United States moved beyond the previous century confident of the virtue of its institutions and of its impregnability. The internal disruption of the war between the states was far behind. The nation filled the entire continent, and its vital interests seemed to reach across the Atlantic and Pacific Oceans. The nation had set itself up as the prime example in the world for other nations to follow as they moved down the road of representative government. There were some, however, who felt that for the United States to sit as the great example of progress was not enough; they sought a role of leadership for the nation in the world community. Senator Eagleton put the thoughts of the day in their proper perspective when he wrote 
that "the United States should lead, should instruct people not yet equiped for self-government and guide them toward the golden way of democratic rule." 86

A number of factors dictated that the United States would lead rather than be just a distant observer. First, this nation had been expansionistic from its very inception. Never had this nation or the original founders been passive, they had always been doers and just because there was a new century they saw no reason to stop taking the initiative. A second factor to consider was the position that America occupied as a result of the industrial revolution. American industrial and economic might was growing at a staggering rate. This expansion would eventually require more markets and those could only be attained through communication with foreign lands usually in line with the standards set down by this country. Finally, the United States could see the demise of the English Empire in its early stages and because of the historical links between the British and the American peoples, it was natural for this country to assume that it might replace the fallen giant in its lofty position.

Two very early actions which set the tone for congressional-presidential intercourse within the field of war powers had occurred by 1903. First, in 1900 President McKinley sent 5,000 American troups to China during the Boxer Rebellion. McKinley defended his action by stating that the move was for the protection of American lives and property. This pretext was very shallow. Schlesinger, writing in his The Imperial Presidency and discussing the Boxer Rebellion, states that "in fact, it was a spectacular case of military intervention for political purposes." ${ }^{87}$ The second issue, which occurred in 1903, was concerned with the action by President Theodore Roosevelt in securing the area

86. Eagleton, War and Presidential Power: A Chronicle on Congressional Surrender, p. 44.

87. Schlesinger, The Imperial Presidency, p. 88. 
of Panama. American hegemony over the Western Hemisphere had been a part of reality within U.S. foreign policy for some time before the turn of the century; however, in an article in the National University Law Review in 1927 , Putney took this assumption a step further. Said Putney, "It was in November, 1903, in connection with the revolution in Panama, that a President of the United States first succeeded in exercising the war-making power without the consent of Congress. The purpose for which such power was exerted on this occasion was so popular a one that it was acquiesced in, with only slight objections, by both the Congress and the public, and a most dangerous precedent for the future was thus created." 88

This executive freedom regarding the deployment and use of the armed forces during this particular period can best be summarized in the words of Roosevelt himself. In a letter to Henry Cabot Lodge shortly before he left the White House, Teddy Roosevelt put into perspective his views of who had the dominant role in managing the forces of this nation. Said Roosevelt, "The biggest matters, such as the Portsmouth peace, and the acquisition of Panama, and sending the fleet around the world, I managed without consultation with anyone; for when a matter is of capital importance, it is well to have it handled by one man only." 89 He did not, of course, define what capital importance meant.

From Theodore Roosevelt and through the administration of William Howard Taft, little change to the policy which had surfaced by 1900 of almost unlimited action on the part of the executive branch of government in war

88. Albert H. Putney, "Executive Assumption of the War Making Power," National University Law Review, Vol. VII, No. 2 (May, 1927), p. 34.

89. Elting E. Morison, ed., The Letters of Theodore Roosevelt, Vol. 6: The Big Stick 1907-1909 (Cambridge:Harvard University Press, 1951-1956), pp. 14971948. 
making was seen. Taft boldly added to the "Roosevelt corollary" that as commander in chief the President could order the army and navy anywhere he saw fit. Taft admitted that this might be beyond the Constitution; in fact, might be a "usurpation of power" on the President's part, yet situations might arise that required such. 90

Taft was followed into the White House by Woodrow Wilson in 1913. Wilson's writings struck the tone of his administration. In 1908 he had written that "one of the greatest of the President's powers" was "his control, which is very absolute, of the foreign relations of the nation." He reiterated this point by stating that "the initiative in foreign affairs, which the President possesses without any restriction whatsoever, is virtually the power to control them absolutely." 91 Once secure in the White House, however, Wilson proceeded with due respect for congressional prerogative on the question of troop deployment. When he sent troops to protect American citizens against the Huerta regime in Mexico in 1914, he felt additionally justified in doing so because the United States did not recognize Huerta, which made his regime, in Wilson's eyes, a nongovernmental organization. After the action began to get out of hand, Wilson applied to the Congress for authority to carry on to a greater degree. Wilson, in asking congressional authority, felt that he could have carried the fight to higher levels without recourse to the Congress and yet not exceed his constitutional powers. Wilson's reasoning for going before the Congress was rather stated this way, "I do not wish to act in a matter of so grave consequence except in close conference and cooperation with both the Senate and the House." 92

90. William Howard Taft, Our Chief Magistrate and His Power (New York:Columbia University Press, 1916), p. 94.

91. Woodrow Wilson, Constitutional Government in the United States (New York:Columbia University Press, 1908), p. 77.

92. Congressional Record, (April 20, 1914), pp. 6908-6909. 
The Congress, while somewhat skeptical toward the degree of Wilson's reactions, voted approval of the action taken. Two years later, when Pancho Villa was murdering American citizens in Mexico and sending raiding parties into New Mexico and Texas, the Senate approved armed intervention; though in this case Wilson's role as commander in chief would have been sufficient to justify his unilateral action to repel invasion. Wilsonian intervention elsewhere in Central America and the Caribbean, Mexico in 1913, Haiti in 1914, the Dominican Republic in 1914, Cuba from 1917-20 and Panama in 1918, was based on the need to protect American citizens or on request by local governments or on treaty provisions. National interest was first and foremost in Wilson's mind and constitutional justification of ten difficult to establish.

During the First World War, Wilson relied much less on the executive war power and much more on the formal action of a declaration of war by Congress. For instance, Wilson went before Congress to request support for his plan to arm American merchant ships. Wilson could see the possible seriousness of the conflict in Europe and he wanted the support of Congress behind his every action.

Despite the President's motives for congressional involvement in the early stages of U.S. participation in the great war; this war, like those before it, proved once again that it is war itself which strengthens the presidency in this critical area. The Fourteen Points were of critical significance to the war and especially to the peace, yet this was entirely a presidential initiative, without congressional consultation or clearance. It is noteworthy that, when Wilson reinforced an American expeditionary force in Siberia after the war, he did not go to Congress for approval. Corwin quotes Charles Evans Hughes during these emotional days of 1920 in light of this action as unsure the republic might last 
through another war. 93

The treaty which brought the First World War to its conclusion was also a shortlived start at congressional rebounding within the field of foreign affairs. Times would soon kill this rebirth as isolationism would grip American foreign policy for the next twenty years. Before his presidency, Wilson thought he knew how to handle the relations between Congress and an executive regarding a treaty. In his Constitutional Government, Wilson spelled out the road he saw as proper when concerned with the treaty problem. A president should act "in the true spirit of the Constitution ... keeping himself in confidential communication with the leaders of the Senate while his plans are on course, when their advice will be of service to him and his information of the greatest service to them." 94 Instead of laying the completed result before the Senate for a final contest of acceptance or rejection, Wilson wrote that the President should really involve the Senate in the informal discussion of what the treaty was about, and this was to take place during, not after, the provisions had been formulated. As President, Wilson, now transformed by the executive perspective, forgot this wisdom. He ignored the Senate while he labored at Versailles; and the Senate, invoking its treaty power, struck back at him. After the failure of the treaty, Congress terminated this country's involvement in the conflict by joint resolution.

The period between the two great wars is often referred to as the age of isolationism in American history. Still, and especially in conducting foreign

93. Hughes stated that, "We may well wonder, in view of the precedents now established whether constitutional government as hitherto maintained in the Republic could survive another great war even victoriously waged." Edwin S. Corwin, Total War and the Constitution (New York:Alfred A. Knopf, 1947), p. 2.

94. Wilson, Constitutional Government in the United States, p. 142. 
policy beyond the Western Hemisphere, the presidency was increasingly an object of congressional mistrust. Some members of Congress and historians considered the First World War as but a plot, the consequence of excessive presidential discretion in foreign affairs. With this in mind, Congress, determined that no one man should again seize control of foreign policy, proceeded to assert itself on all issues of external relations that might involve the nation in war. Schlesinger concludes that the Congress had "astonishing success", 95 especially when one considers the state of the domestic crisis during this period. What Schlesinger does not consider, and is very important during this time, is the large amount of leeway which was afforded to the President in domestic affairs. This trend would soon overlap into foreign affairs in a way and to a degree never imagined by the gathering at Philadelphia.

During most of the 1920's and 1930's American force abroad was used sparingly, in part because of a more relaxed approach to the difficulties of the Latin American states and in part as a result of a strong popular desire to avoid involvement in the struggles of the world's other great power. Reveley describes the reluctance of American involvement in foreign affairs as a direct response to World War $1 .{ }^{96}$ The mood of the nation showed itself vividly when Japanese bombers deliberately sent an American gunboat, the Panay, to the bottom of the Yangtze River on December 12, 1937. Quite unlike the popular reaction to attacks on the Maine and on destroyers in the Tonkin Gulf, the Panay incident gave immediate and trememdous impetus to a congressional attempt to amend the Constitution to subject war decisions to popular referendum, except in case

95. Schlesinger, The Imperial Presidency, P. 95.

96. Reveley, "Presidential War-Making: Constitutional Prerogative or Usurpation?," p. 1262. 
of invasion. 97 Instead of a round of condemnation for the acts, Washington eagerly accepted Tokyo's explanations and apologies. The State Department quickly agreed that the attack had been a mistake. William Manchester, in his The Glory and the Dream, assessing the State Department view said, "the likeliest explanation was that it had been a test of American nerve. They (the Japanese) knew now that America was a paper tiger." 98

This general attitude of pacifism was to continue into the early days of the 1940's. What occurred in Europe or Asia was not important to the American people as long as fortress America stood. A repetition of the last war's insensate horrors was unthinkable. America's European allies of 1918 were despised as people who welshed on their debts. Japan was many thousands of miles away. Antagonism toward external adventurism found much political expression. These feelings were compounded by ignorance. The great depression had obscured foreign affairs by turning the country inward. Americans simply had no time for the troubles of other nations. At each deepening of the international crisis which lead to the next war, their attention had been diverted by developments at home. The men who went down with the Panay were not forgotten, but the time to speak for them had not arrived. Prevention of war was the paramount issue of the day; discussion in the opposite direction was unthinkable.

97. "At every session, amendments to the Constitution were proposed to alter the war-making clauses. The most frequent were designed to halt profiteering, to bar using conscripts outside the continental United States, to require that a declaration of war pass each house by a three-fourths vote rather than a simple majority, and to hold a popular referendum, except in cases of invasion, before a congressional decision to go to war could take effect." Leopold, The Growth of American Foreign Policy: A History, pp. 416-417, 534.

98. William Manchester, The Glory and the Dream:A Narrative History of America 1932-1972 (Boston:Little, Brown and Company, 1973), p. 210. 
Franklin Roosevelt was one of the few who recognized what was happening and spoke of it. Two months before the Panay incident, speaking at a dedication ceremony in Chicago and referring to what was going on in Europe, FDR stated that "the epidemic of world lawlessness is spreading. When an epidemic of physical disease starts to spread, the community approves and joins in a quarantine of the patients in order to protect the health of the community against the spread of the disease. Peace-loving nations must act in concert with other nations of the world community."99 The President's speech caught the nation's attention, but not as he had planned. The howls of protest were deafening. Editorials and personal mail charged him with warmongering. Clearly, the nation was not yet ready to become embroiled in another war. Roosevelt was immediately put on the defensive and any role that he envisioned for the United States at that time, in the affairs in Europe or Asia, was shelved for the time being.

Congress had seen Roosevelt leaning toward participation in the conflicts which raged in Europe and Asia. By 1935 and again in 1936 and 1937, Congress had passed Neutrality Acts which sought to keep this country from any involvement in the crisis on both fronts. Public opinion polls went along with this action. As mentioned above, FDR ran into trouble at the very mention of international involvement. To Roosevelt, however, it was equally clear that fascism and Nazism could not be allowed to expand. Like anyone else, the President did not wish to see war again; however, when open war broke out in Europe in September 1939, Roosevelt believed that the United States had a special obligation to Great Britain and France and he urged legislation to revise the Neutrality Acts so that this country could aid the beseiged nations. These requests fell on deaf ears on Capital Hill. 
In 1940 the President totally circumvented the legislative process by concluding a deal with Prime Minister Winston Churchill of Britain whereby the United States provided fifty outdated but reconditioned destroyers to Great Britain in exchange for naval bases in the Western Hemisphere. This bold expansion of presidential power, defended by Roosevelt's Attorney General, ${ }^{100}$ was only the beginning of his enlargement of the presidential prerogatives as commander in chief before and during World War II.

What is extraordinary about the destroyer deal is the public reception of the agreement, especially after studying the attitudes of the country just a few short months before. Seemingly, the view of an inevitable confrontation with the European aggressors had captivated not only the American people but a substantial number in Congress as well. The Congress, by voting money to build the bases on the sites acquired, gave the deal its implicit sanction.

There was, however, an element in Congress which sought to keep the United States out of the war which had raged, unchecked, since 1939. Congress, while realizing that a grave period lay before the nation, was not yet ready to give the power of war to the President. This view was amply reflected as late as the summer of 1941, a year after the fall of France, by action in Congress. When considering an extension of the draft law, debate was so heated that in the House the extension passed by only a one vote margin. This law, like the previous one, stated that American draftees could not be sent out of the Western Hemisphere, an interesting point which was to later haunt President Roosevelt. Under the circumstances and with the anti-interventionist sentiment crystal

100. The Attorney General, Robert H. Jackson, stated that the destroyer deal could be made through executive action. His opinion also concerned itself with the commander in chief clause as giving the president this power. Finally, he stressed the acquisition of bases over the delivery of destroyers. (George H. Skau, "Franklin D. Roosevelt and the Expansion of Presidential Power," Current History, Vol. 66, No. 394 (June 1974), p. 248). 
clear, FDR undertook an extraordinary series of executive actions, which sought to hem in Japan economically and to help the nations fight Germany and Italy more effectively. Weeks before Pearl Harbor these moves included an order that in effect meant convoying of marine supplies to the allied powers despite the existence of a congressional ban on such action. Also, President Roosevelt issued order to the Army, Air Force and Navy to shoot first at German and Italian vessels found in the western Atlantic. Eric F. Goldman surmises that these actions by the President amounted to "de facto warfare,"101 without the approval of the Congress as prescribed by the Constitution,

Throughout the study of the Roosevelt presidency prior to the open involvement in World War II, the President seems to have built his own credibility gap, which he could not shake; but if one looks very close, he had no reason to attempt to escape from it. While Roosevelt rolled along toward the war and while he gave Congress only defensive concern regarding his actions he was able to get away with it. Congress seemed to be in a fiesty mood toward this presidential usurpation; however, Roosevelt had the weight of the nation on his side. Fresh from a third successful campaign for the White House, the President was very popular in the nation and his first eight years had been tremendously successful in domestic politics. Why should the public feel at all insecure with this President in foreign affairs?

After the Japanese attack on Pearl Harbor expansion of the federal government, particularly those of the executive branch, played an important role in controlling every level of American society. During this war, as in past wars, the American people were accustomed to making sacrifices and granting unusual

101. Eric F. Goldman, "The President, the People, and the Power to Make War," in The Vietnam War and International Law, Vol. III, ed. by Richard A. Falk (New Jersey: Princton University Press, 1969), p. 496. 
discretionary powers to the executive. Roosevelt seized on these attitudes to strengthen the powers of the President while also winning the war. He applied this new found power not only in the foreign affairs area but he extended his powers in domestic politics as well. For instance, in 1942, when Congress ignored his plea for repeal of a farm subsidy which the President felt would be inflationary, Roosevelt stated that "in the event that Congress should fail to act, and act adequately, I shall accept the responsibility and I will act ... The President has the powers, under the Constitution and under congressional acts, to take measures necessary to avert a disaster which would interfere with the winning of the war ... When the war is won, the powers under which I act automatically revert to the people - to whom they belong." 102

What should be remembered about this second stage of the evolution of the President's war making powers is that it resembled the period just before World War I. A semblance of congressional authority was preserved by the ultimate declaration of war in both; however, war was actually being fought in varying degrees long before Congress gave its stamp of approval. Plenty of angry comments were made about this, yet the war making power did not become a major national issue. Again, Roosevelt was widely popular and a clear distinction between good and evil was easily made by the public.

The third stage in this spiraling ascendency of the President regarding war powers was a direct result of the Second World War and the Cold War years which followed. Never again would the war powers be considered in quite the same way. The one factor which had the most to do with this new view of war was the atomic bomb and its usage. The decision to make war became one of not just the destruction of a society; it was now the destruction of the entire world. 
President Truman accepted responsibility for the use of the weapon on the Japanese. Whatever controversy surrounds his choice of the usage of the bomb, and it is debated to this day, there can be no doubt that he acted legally. Truman was performing his constitutional role as commander in chief in a declared war.

Eagleton speaks of the atomic bomb as giving the modern-day myth of the superiority of presidential decision-making its birth. ${ }^{103}$ However, the birth of the bomb and its application to a war situation did not totally eliminate the legislative branch of government from the war powers decision. As late as 1945, Congress, seeing the United Nations Charter obligate the U.S. to enter a conflict prior to congressional approval enacted the United Nations Participation Act which carefully restricted the President's authority to negotiate agreements with the U.N. under which American troops might be assigned to peace keeping tasks around the world. This particular act specifically stated that "nothing herein contained shall be construed as an authorization to the President by the Congress to make available to the Security Council ... armed forces, facilities, and assistance provided for in such special agreement or agreement."104 Once Congress approved a particular participation agreement, no further legislative action would be necessary to commit troops to a peace keeping force. Undoubtedly Congress saw this act as securing its power over the deployment of U.S. troops abroad; however, in reality those powers had been absent for some time. A clause like this also was attached to the North Atlantic Treaty which was negotiated three years later. Several Senators worked with the State Department in negotiating the NATO treaty, yet a clear understanding did not

103. Eagleton, War and Presidential Power: A Chronicle on Congressional Surrender, p. 67. 
surface even during Senate debate of the treaty. ${ }^{105}$

All treaties and clauses aside, it was early in this third stage of the evolution that one sees perhaps the most striking action undertaken by the executive on his own initiative within the war powers controversy, in the action in Korea (Vietnam might be considered as an equal here; however, the conflict in Southeast Asia did not start as suddently and dramatically). President Truman's decision to commit U.S. troops to repel the invasion of South Korea was done without a congressional approval ever being sought.

In defending the President's action, the State Department argued that it had been taken under the United Nations Charter, which is part of both the treaty and international law that the President carries out; and to protect United States interests. The State Department went on to say that the authority rested with the President's role as commander in chief. ${ }^{106}$

105. Negotiators from the Senate felt that the implementation of the treaty could only be made through the consent of the Congress. When the treaty was before the Senate many questions regarding U.S. participation arose. Senator George, the ranking member of the Foreign Relations Committee, told his colleagues:

The Secretary of State, who was the spokesman for the administration, then interpreted the words "constitutional process" to mean congressional approval insofar as a declaration of war or the employment of our troops in any foreign country was concerned, and that language was designedly inserted into the treaty.

This statement was followed by the question from Senator Arthur Watkins of Utah, who asked:

I want to know if Article 11 means that the provisions of this treaty are to be implemented by the Congress.

In reading hearings on the treaty confusion raged within the Senate as to just what the congressional process was. At no time did a clear understanding come forth which could satisfy many in attendance. Eagleton, War and Presidential Power: A Chronicle on Congressional Surrender, p. 69.

106. "The President, as Commander in Chief of the Armed Forces of the United States, has full control over the use thereof. He also has authority to conduct the foreign relations of the United States. Since the beginning of United States history, he has upon numerous occasions utilized these powers in sending armed forces abroad. The preservation of the United Nations for the (contd.) 
In deploying troops to Korea, Truman acted without an authorization of any kind. American air and naval support were ordered into the southern half of that divided country to meet Communist aggression from the north, before any formal presentation by the President to the Congress of the facts of the Korean situation. The President could hardly claim he was responding to an attack upon the United States or any of its citizens. Neither could he claim to have even acted under a mutual defense treaty, as none existed with the particular nations involved. Protection of American lives would have been Mr. Truman's defense.

A clear fallacy could be found in the State Department's memo mentioned above. Contrary to the statement from the State Department, Truman lacked any United Nations support or mandate when he initially committed American forces to South Korea. By simply saying the troops were already there is insufficient. Only after Truman acted did the Security Council, in the absence of the Soviet Union, pass a U.S.-sponsored resolution calling for volunteer national units to repel the invaders. More importantly, even if this resolution had preceded the President's deployment of troops, it would not have justified his

106. (contd.) maintenance of peace is a cardinal interest of the United States. Both traditional international law and Article 39 of the United Nations Charter and the resolution pursuant thereto authorize the United States to repel the armed aggression against the Republic of Korea.

The continued defiance of the United Nations by the North Korean authorities would have meant that the United Nations would have ceased to exist as a serious instrumentality for the maintenance of international peace. The continued existence of the United Nations as an effective international organization is a paramount United States interest. The defiance of the United Nations is in clear violation of the Charter of the United Nations and of the resolutions adopted by the Security Council of the United Nations to bring about a settlement of the problem. It is a threat to international peace and security, a threat to the peace and security of the United States and to the security of United States forces in the Pacific. These interests of the United States are interests which the President as commander in chief can protect by the employment of the armed forces of the United States without a declaration of war."

Hearings before the House Committee on International Relations, "Background Information on the Use of U.S. Armed Forces in Foreign Countries 1975 Revised," 94th Cong., 1st Sess., p. 24 (1975). 
action. The Participation Act mentioned earlier was required to be implemented before any formal commitment of troops to the United Nations.

The Truman administration further defended its action by stating that if it had not immediately sent troops into South Korea, that nation would have fallen to the army of North Korea. Though one can only speculate on this assumption, it was probably a correct assertion. An important point to keep in mind at this time is that the Congress of the United States, according to Senator Eagleton, "sympathized with South Korea's plight and in all probability would have endorsed supportive action." 107 The question which rises from this controversy is that if the Truman administration was able to take its case to the Security Council the day following the invasion, why could it not do the same thing concerning the Congress? Both the Security Council and the Congress are deliberating bodies, and a positive opinion from within would seem easier to attain than going before an international body, especially had the Soviets been present.

Korea was but one problem that Truman had with the troop deployment question, however, it must be considered the height of the controversy surrounding his administration. Had it not been for Korea, the issue of sending additional troops to Europe in early 1951 might be considered the landmark case for questioning the roles of the President and the Congress when determining war powers and military policy, at least until Vietnam. The "Great Debate" over troops to Europe was generated after President Truman's announcement in September 1950 that he planned to send additional ground troops to Europe as part of the projected build-up of NATO forces. This announcement stirred attacks from all sectors of the Congress and eventually led to the passing of

107. Eagleton, War and Presidential Power: A Chronicle on Congressional Surrender, pp. 71-72. 
Senate Resolution $\$ 99,{ }^{108}$ which sought a greater voice for Congress in future deployment plans.

Dwight D. Eisenhower was elected President in 1952 and brought a rather different approach into the White House regarding the sharing of power with Congress when formulating foreign policy. A military hero, lke was as devoted to the principle of civilian control over the military as any President in our history. He believed that a President should assure himself of congressional support for whatever course he might be forced to take. Early in his first term in office he received a request for aid from the French who were doomed to defeat in the French Indo-China War. After a hastily called meeting with leaders of Congress, which took place on a weekend and which Eisenhower himself did not attend, it was decided that U.S. involvement (which might include manpower) was out of the question, at least to the degree that the French requested. 109

Throughout his two terms in the White House, Eisenhower involved Congress in the policy he was considering. Whether this policy was his or was established by his Secretary of State John Foster Dulles is not the question here; that he did include Congress, to a degree at least, was refreshing. Ike's determination to follow this course accomplished several different ends which helped the President. First, his administration can be said to have met and passed the traditional test of constitutionality within the scope of the executive versus the Congress in the field of foreign affairs. Second, Eisenhower found

108. This resolution, adopted April 4, 1951, expressed approval of present plans to send four divisions of ground troops to Western Europe, but stated it was the sense of the Senate "that no ground troops in addition to such four divisions should be sent to Western Europe without further congressional approval."

Hearings before the House Committee on International Relations, "Background Information on the Use of U.S. Armed Forces in Foreign Countries 1975 Revised," 94th Cong., 1st Sess., pp. 67-68.

109. Chalmers M. Roberts, "The Day We Didn't Go to War," The Reporter, September 1954, pp. 41-48. 
that by explaining situations to Congress which seemed to risk U.S. military engagement, he was able to use Congress as a sounding board, in that Congress was closer to the people and could better read their will and attitudes. Finally, the President's action built stability in the policies of this nation. With Congress' support, Ike could move in a much bolder way in the international arena, as America's adversaries could see a united force moving out from these shores.

This approach was used by the President several times, the most significant being the resolutions which he requested concerning the instability which existed in the Far East in 1955 and again in 1957 concerning the Middle East. These two congressional resolutions, while similar in many aspects, also signaled the end of any role for Congress in foreign policy. This paradox must be explained. First, the Taiwan Resolution was intended to stop the overzealous Chinese of mainland China from overrunning the Republic of China with which the United States had a security treaty. A number of small islands in the Formosa Straits had not been included in the treaty and the Peking government sought to claim them. The process was begun through bombardment and general harassment by the mainland Chinese. Eisenhower looked for a way to inform the Peking government that it could not count on continuing these military assaults without serious risk of retribution. He did not, however, want to tie the United States to the defense of these islands under all circumstances. So, the President asked Congress for a mandate allowing him to do whatever might prove necessary to preserve the stability of the situation in that area. Eisenhower did not say what powers he had or what he might do without congressional approval. He saw the question here as being too difficult to draw a clear line; he wanted a joint statement by Congress and himself as to what they considered enough in the area and what the Chinese could expect if they did not cease their actions. Congress thus gave Ike any discretionary power he might feel necessary. 
In discussing the Taiwan Resolution, Eagleton sees this action as giving the Congress a chance to emerge with a role in war making but not grasping this possibility. He concluded that while Congress had given birth to hope in this area "the next time that the Congress was asked to consider pledging American military might, it virtually abrogated its constitutional duty." 110 Eagleton's criticism of Congress was in connection with its passing of the Middle East Resolution in 1957. As a result of the vacuum created in this very explosive area with the withdrawal of British and French power, Eisenhower and Secretary of State Dulles feared Communist activity. With these fears in the back of his mind the President wanted a clear mandate to respond promptly to any request made by any one of these nations for military help against such aggression.

The President's request for such a mandate had many varying interpretations. Some felt his request for power to use military force in this way was an attempt to preempt congressional authority. Others argued that the President did not need the resolution, that he had sufficient power as commander in chief to use the armed forces anywhere to protect the vital interests of the United States. Rather than authorize the President specific powers, the resolution came out of Congress exactly as the White House wanted. Congress implied that the President need not ask its permission to do what he had in mind. The resolution read in part that "if the President determines the necessity thereof, the United States is prepared to use armed forces to assist any nation or group of nations requesting assistance against armed aggression from any country controlled by international communism." 111 If this was not a blank

110. Eagleton, War and Presidential Power: A Chronicle on Congressional Surrender, p. 74.

111. Hearings before the House Committee on International Relations, "Background Information on the Use of U.S. Armed Forces in Foreign Countries 1975 Revised," 94 th Cong., 1st Sess., pp. 69-70. 
check it must at least have been a signal to the White House that Congress did not wish to be included further in any Middle East problems.

The relationship between Congress and the President had some high points, but most of the third phase must be considered as a low ebb for Congress. The Cold War and the Communist scare of the McCarthy era established bipartisan backing which even the most dominating executive could not have foreseen. What is also startlingly clear about this period is that while the executive received the backing of the legislative branch of government, this branch must have given its support agonizingly.

In 1960, even such liberals as John Kennedy, who later would seem very conservative, spoke of the dominating role of the executive. Early in the year Senator Kennedy claimed that however large the congressional role in domestic policy, "it is the President alone who must make the major decisions of our foreign policy." 112 Dean Rusk, who would soon become JFK's Secretary of State commented that "as Commander-in-Chief the President can deploy the Armed Forces and order them into active operation. In an age of missiles and hydrogen warheads, his powers are as large as the situation requires." 113

This was the prevailing atmosphere when Kennedy became President in 1961. Kennedy entered the White House after gaining a very small majority in the election and his majority in Congress was illusionary in that it consisted of a number of southern Democrats who voted along conservative lines and much like Republicans. Kennedy was also influenced by his years in both the House of Representatives and the Senate. Being from the Roosevelt school of strong executives, he saw the foreign policy of the last eight years as weak. He was determined not to let this continue in his administration.

112. Schlesinger, The Imperial Presidency, p. 169

113. Dean Rusk, "The President," Foreign Affairs, Vol. 38, No. 1 (April 1960), p. 4. 
As a Senator in the 1950 's Kennedy had grave doubts that America's armaments were equal to her commitments. He was generally opposed to the "New Look" weakening of the Army manpower which had come out of the presidential-congressional defense planning institutions. Once a candidate for the highest office in the land, Kennedy spoke out for strengthening U.S. capabilities for massive retaliation. In addition, he sought build-ups in the conventional forces of the nation. Shortly after his election, JFK set the tone of his administration vis-a-vis Congress by attempting to remove the "purse strings" power of that body. In his first policy change regarding defense spending Kennedy announced to Secretary of Defense Robert McNamara that "under no circumstances should we allow a predetermined arbitrary financial limit to establish either strategy or force levels." ${ }^{114}$ He felt this was not a domain of the Congress.

Attitudes like these dictated the actions of the early period of the Kennedy term in office. The best example of presidential disregard for the Congress in the area of war making in the early days of the new administration had to be the Bay of Pigs fiasco. Shortly after the election Kennedy learned for the first time that the outgoing Eisenhower administration had decided to equip and drill Cuban exiles for possible action against the Castro regime in Cuba. In a pre-inauguration meeting with Eisenhower, the President stated that "it was the policy of this government to aid anti-Castro guerrilla forces to the utmost." Eisenhower recommended that "this effort be continued and accelerated." ${ }^{115}$ Ike stressed that the Bay of Pigs operation was not to be disclosed to Congress. This closed the final chapter on the relationship between Eisenhower and the 603.

114. Theodore C. White, Kennedy (New York:Harper \& Row, 1965), p.

115. Arthur M. Schlesinger, A Thousand Days (Cambridge:HoughtonMifflin Company, 1965), p. 164. 
Congress and it opened the door for continuation of such a policy by the incoming executive. What is astounding, when considering this plan, is that the United States had full diplomatic relations with Cuba and at the same time was planning to support an invasion of the island nation, yet it never occurred to Eisenhower to even discuss the project informally with the senior members of Congress. Ike's suggestion was an obvious contradiction of his early relationship with Congress and Kennedy agreed completely.

After the Bay of Pigs disaster Kennedy took steps to rein in the Central Intelligence Agency, who had been given a blank check on operations in Cuba by the previous administration. The new President became very skeptical regarding the intelligence community and established the so-called 303 Committee as a mechanism for executive initiation of policy.

The greatest crisis during the Kennedy years, and possibly since World War II until this event, was the Cuban Missile Crisis of 1962. The management of this great foreign policy adventure by Kennedy lends credence to the proposition that the nuclear age has left no alternative to unilateral presidential decision. However, a closer look at the situation may throw a different light on this assumption. Richard J. Walton has written a book which, while instilled with revisionism, put the October 1962 crisis in a different perspective than most writers have. Says Walton, "it has been widely accepted that the Cuban missile crisis was the occasion of John Kennedy's greatest triumph. I disagree. I believe that his decision to go to the brink of nuclear war was irresponsible and reckless to a supreme degree, that it risked the kind of terrible miscalculations that Kennedy was always warning Khrushchev about, that it was unnecessary, and that, if one assumes minimum competence, the Kennedy administration knew it 
was not necessary." 116 The President's actions were controlled by a small ad hoc group that came to be know as the ExCom. It was composed of a constantly shifting combination of top officials from the White House, the State Department and the Pentagon; plus Attorney General Robert Kennedy, Treasury Secretary Douglas Dillon, and Dean Acheson. No members of Congress were included in the formulating group which brought this nation so very close to all out nuclear war. While a number of Congressmen were asking questions about Soviet activities in Cuba, most of it was merely campaign jargon.

It was only after he had made his decision that Kennedy called in the congressional leadership. The object was not to consult but to inform. Some members felt that the quarantine was not enough ${ }^{117}$ but none raised the question of why they had not been included in the formulation of the decision. That Kennedy should have included members of Congress in his ExCom goes without saying. This would not have affected the constitutional question since membership on a select executive committee could not supersede formal congressional action.

However, criticize as one might, war was averted in the missile crisis. This crisis was unique in the postwar years in that it really combined all those pressures of threat, secrecy, and time that the foreign policy establishment had, and still does, claim as characteristic of decisions in the nuclear age. It would

116. Richard J. Walton, Cold War and Counterrevolution:The Foreign Policy of John F. Kennedy (New York:The Viking Press, 1972), p. 103.

117. For Instance, William Fulbright advocated the invasion of Cuba by American forces however, he qualified that opinion later. In considering his earlier view he stated that "had I been able to formulate my views on the basis of facts since made public rather than on a guess as to the nature of the situation, I might have made a different recommendation."

J. William Fulbright, The Arrogance of Power (New York:Harper \& Row, 1965), p. 48. 
seem that in all the other independent and unilateral presidential actions of the period, the threat was less grave, the need for secrecy less urgent, and the time for debate less restricted. Richard Walton's and all the other revisionists argument should be considered; however, in a final analysis, while the management of the crisis may be open to some criticism, it is hard to knock success.

Arthur Schlesinger is very complimentary of Kennedy in his handling of the Cuban situation; however, he is highly critical of the rule which he says was born as a result of the situation. While concluding that the crisis shows a need for some presidential initiation in the field of war making powers, Schlesinger adds that "one of its legacies was the imperial conception of the Presidency that brought the republic so low in Vietnam." 118

What, then, of the Vietnam period in American history. Today, when thinking of Vietnam and the whole of the tragic experience of this nation in Southeast Asia, names like Lyndon Johnson and Richard Nixon come to mind. These names should not be confused with the initiation of this country's involvement in Asia. Rather, one should look to Roosevelt, Truman, Eisenhower, and Kennedy for this background. The policy of containment which was set in motion by President Truman but may have its roots in the last days of FDR's life, might be considered the backbone of America's Vietnam policy. Once this nation was dedicated to encircling the communist world and once this country had refused to aid the nationalist movements in Indo-China, the writing was on the wall. By 1954 President Eisenhower pledged United States assistance to the Vietnamese government to help make South Vietnam "capable of resisting attempted subversion or aggression through military means." By 1957 Ike placed

118. Schlesinger, The Imperial Presidency, p. 176. 
the growing conflict of the Asian nation in a much larger perspective when he stated that "aggression or subversion threatening the political independence of the Republic of Vietnam would be considered as endangering peace and stability" $^{119}$ world-wide. President Kennedy made asurances much like these shortly after assuming office.

These assurances fell short of a promise to engage in war. They could not have misled the Vietnamese, for these same Presidents stated that our assistance would not take the form of troops. Yet, after the horror of Dallas in November 1963 and after Johnson became President, he stated that he was fulfilling commitments of past Presidents. Those commitments, by the end of the Kennedy days in the White House, included nearly 20,000 advisors. Even with the large number of troops in that nation and after the Gulf of Tonkin Resolution was passed, Johnson declared on October 21, 1964, that "we are not about to send American boys 9 or 10,000 miles away from home to do what Asian boys ought to do for themselves." 120

Mention of the Gulf of Tonkin Resolution brings pains of anxiety to many students of foreign policy, particularly when considering the issue of war powers. What brought about this move by Congress? First, it must be recognized that much of the evidence provided by the Johnson administration as to what was actually occuring in the Tonkin Gulf is questioned today, but was accepted by all but two members of Congress. They, Senators Wayne Morse of Oregon and Ernest Gruening of Alaska, were the only two dissenting votes in the entire Congress. Their arguments were constitutional rather than evidential. p. 777.

119. Wormuth, "The Vietnam War:The President versus the Constitution,"

120. Public Papers of the Presidents: Lyndon B. Johnson, 1963-1964 (Washington D.C.: Government Printing Office, 1965), p. 1391. 
President Johnson came before Congress in August of 1964 seeking a resolution which would give the opinion of the Congress concerning how the situation could be handled. Johnson maintained that two U.S. destroyers were attacked while cruising in the Tonkin Gulf in early August. He did not add that these vessels might have been supporting South Vietnamese naval attacks against North Vietnam. What he wanted was power to retaliate against these alleged attacks. Nearly all of the leaders of Congress felt it was a fine idea, especially after Johnson reminded them of the criticism that Truman had come under for not going before Congress pursuant to his policy in Korea. The resolution, written by the administration, provided "That the Congress approves and supports the determination of the President, as Commander in Chief, to take all measures necessary to repel any armed attack against the forces of the United States and to prevent further aggression," and that "the United States is, therefore, prepared, as the President determines, to take all necessary steps including the use of armed force" to assist Cambodia, Laos, South Vietnam, Australia, New Zealand, Pakistan, The Philippines, Thailand, and the Asian possessions of Great Britain and France to maintain their freedom if requested to do so. ${ }^{121}$ The language of the resolution was very vague, yet it offered the executive very broad powers and discretions. While the constitutional question here was brought forth by Morse and Gruening the issue was not belabored. What the resolution did was to give the President a blank check to determine policy in the whole of Asia. During the deliberations, Senator Sherman Cooper asked the resolution sponsor, Senator Fulbright, "looking ahead, if the President decided that it was necessary to use such force as could lead into war, we will give that

121. Wormuth, "The Vietnam War: The President versus the Constitution," p. 781. 
authority by this resolution?" And Fulbright replied, "That is the way I would interpret it." 122

A number of interesting questions arise from the resolution. First, did the last phrase of the resolution, which allows the President to take all measures necessary to repel further aggression, mean that the President could move freely anywhere in Southeast Asia? Did the resolution mean Congress was delegating its war making powers to the President or was it acknowledging his pre-existing authority to do whatever he found necessary? Also, was the resolution to be interpreted in a way which meant that all the American people were in favor of unrestricted activity by the President?

Whatever the exact significance, the language on its face gave the President remarkable scope. Johnson maintained that he already had the authority as the commander in chief to do what the resolution acknowledged. The significance of the resolution in Johnson's view was exclusively political. In his memoirs, Johnson wrote that "Part of being ready, to me, was having the advance support of Congress for anything that might prove to be necessary." 123 It should be noted that Johnson used the term congressional support, not congressional authority. He did not for one minute believe that the resolution gave him any legal authority that he did not already have.

Thus the Johnson years in the White House were marked by a role of support rather than sanction concerning Congress and war powers. Some believe that the President could have obtained congressional authorization beyond the Tonkin Resolution for a limited war in Vietnam. Why would this have been necessary, however? Neither Johnson nor most of Congress thought formal

122. Congressional Record, Vol. 110, Part 14, 88th Cong., 2nd Sess. (August 5, 1964), p. 18409 .

123. Lyndon B. Johnson, The Vantage Point: Perspectives of the Presidency 1963-1969 (New York:Holt, Rinehart and Winston, 1971), p. 116. 
congressional action was necessary. Under Secretary of State Nicholas Katzenbach went even further with an analysis of the resolution. According to Katzenbach, this resolution, along with the SEATO arrangements, constituted the "functional equivalent" of a declaration of war."124

Much of the background for justification of the war in the last two years of the Johnson administration and well into the Nixon presidency was built around a legal memo submitted to the Senate Committee on Foreign Relations by the State Department in 1966. This memorandum presented to the Committee on March 11, 1966, and written by the Legal Adviser of the State Department, ${ }^{125}$ despite its brevity, proved to be the fullest statement ever made of the legal case for the initiation of the war in Vietnam. The memo offered several arguments to back the administration's claims. Briefly, this legal statement concluded that the framers of the Constitution had qualified the war clause. They intended that the President be free to repel sudden attacks upon the United States without congressional authorization; however, even in this age of a shrinking globe, this could not mean half way around the world as the memo seemed to conclude. The legal adviser also brought forth well over one hundred cases of unauthorized executive use of military force which he said supplied validity to the actions of Presidents regarding Vietnam. Justification through the Tonkin Resolution and through SEATO were also forwarded. Finally, said the brief, by passing appropriation acts, the Congress had endorsed the war.

While Congress must accept some responsibility for the continuation and even the escalation of the Vietnam War their political hands were tied. Silent support should not be construed as wild endorsement.

124. Schlesinger, The Imperial Presidency, p. 182.

125. Leonard Meeker, "The Legality of United States Participation in the Defense of Vietnam," Department of State Bulletin No. 54 (1966), pp 1085-1108. 
A history of the turbulent late 60 's which drove Lyndon Johnson from the White House is not necessary here. Suffice it to say that the national upheaval which consumed the nation in the mid-60's was reaching its high point by 1968 . Johnson became the goat for a war which he certainly did not start, but which he enlarged a great deal. He had become not only a target for the public and the press regarding Vietnam, but he came under fire from an enraged Congress which saw the benevolent President expanding the war at a frightening pace. By March of 1968, Johnson had been chased out of Washington and that fall Richard Nixon was elected as the thirty-seventh President on a campaign pledge to end the war, a pledge which the Democrats could not make.

The new President said he had a secret plan to end the war. But as events soon showed, the plan of 1968 was as short-lived as most campaign speeches. While Johnson had been removed from the White House, his policy remained. The idea of presidential prerogative in the field of war making was well rooted in American institutional history and in public opinion, but changing of faces would not conceal that history from view.

President Nixon continued to pursue the war along the same lines as the Johnson administration before him. He withdrew some of the legal justifications from the State Department brief mentioned earlier but replaced them with others. For instance, the Nixon administration did not rely on the SEATO treaty. This treaty did not, after all, authorize war but left this action to be taken, if necessary, through the constitutional process of each signatory nation. President Nixon also discarded the Tonkin Resolution when he signed the congressionally passed repealer on January 12,1971. These moves would seem to strengthen the Congress vis-a-vis the President; however, to the contrary, they opened new doors, or widened doors already ajar, for further usurpation. 
What Nixon did was to emphasize that part of the legal brief which gave the President authority through the commander in chief clause. Francis D. Wormuth put the Nixon concept of the war powers in perspective when he wrote that the Nixon administration understood the granting of executive power in the Constitution to mean that the commander in chief could initiate war. ${ }^{126}$ Wormuth concludes that action by the United States is strongest when the Congress and the President act in harmony; therefore, the Nixon people saw the country as strongest when the Congress was loyally supportive of the President. In closing, Mr. Wormuth states that attitudes like this by the executive branch of government were called "fuehrer-prinzip," ${ }^{127}$ during an earlier point of history.

This concept of a "fuehrer-prinzip," or commander in chief, if you like, was thus to acquire yet more power in the $70^{\prime} \mathrm{s}$. The repeated use of the term would have confounded the founding fathers. As we have seen, the office through most of American history had a strictly technical connotation: it meant no more than the topmost officer in the armed forces. It would seem that for this official to determine such important issues as war and peace, one would have to live in a military dictatorship. However, by the early 1970 's, the title of commander in chief had acquired almost a sacramental aura, translating its holder from wordly matters into an imaginary realm of higher duty. In the spring of 1970 when Nixon announced the incursion into Cambodia he compared his actions to Kennedy's regarding the Cuban Missile Crisis. His authority, which was contained in the commander in chief clause was used in a great moment of decision, much as Kennedy had used his to remove the missiles from Cuba. When Nixon was blasted with inquiries as to why Congress had not been informed in advance, he

126. Wormuth, "The Nixon Theory of the War Power:A Critique," p. 624. 127. Ibid., p. 625. 
defended his action by stating that "in the modern world, there are times when the Commander in Chief ... will have to act quickly. I can assure the American people that this President is going to bend over backward to consult the Senate and consult the House whenever he feels it can be done without jeopardizing the lives of American men. But when it is a question of the lives of American men or the attitudes of people in the Senate, I am coming down hard on the side of defending the lives of American men." 128

It seems very hard indeed to believe that Nixon could seriously have considered Cuba and Cambodia equivalent situations. How could one consider the two equal in their danger to the United States, as equal in their need for secrecy, or as equal in their lack of time for congressional consideration? The enemy bases and the threat to American forces from these bases had existed in Cambodia for years; I can personally attest to this. What could the sudden emergency have been in April 1970? Most of the enemy areas had already been evacuated by the time of the invasion. Above all, there was ample time for congressional consultation.

In the case of Cambodia Nixon went beyond limiting the Congress, he did not even include many of his supposed trusted advisers in making this decision. Says Schlesinger, in the case of Cambodia, "Nixon, instead of exposing himself to a candid discussion among even his closest colleagues, seems to have withdrawn into solitude and sprung his unilateral decision on them as well as on the world." 129 This practice became more and more the standard procedure for enacting the war making doctrine under President Nixon, especially after Dr. Henry Kissinger established his mini-State Department and eventually took over

128. Richard M. Nixon, "A New Road for America: Major Policy Statements" (New York:Doubleday, 1972), p. 687.

129. Schlesinger, The Imperial Presidency, p. 190. 
at the actual State Department from William Rogers. This is not to say that Rogers was any less inclined. In an article in 1971 Rogers boldly expanded presidential power in determining war making by concluding that unauthorized executive coercion of small countries (like Cambodia) might be valid by their defenselessness. Specifically, stated Rogers, "There being no risk of major war, one could argue there was no violation of Congress' power to declare war." ${ }^{130}$ It appears clear that the President was encircled by individuals who felt that as President he could extend military action or initiate military action in nearly any field he wished without the least concern for the role Congress was to play. Rogers, in particular, seemed to be establishing a role for Congress in declaring war only in a major conflict; yet the Constitution did not distinguish between major wars and minor wars. Using this principle, the President might destroy a small state with nuclear weapons simply because that nation had no powerful friends to resist such an action.

Johnson and Nixon indulged in presidential war making beyond the boldest dreams of their predecessors. Those who had stretched the executive war power to what had seemed its outer limits in the past had done so in the face of visible and serious threat. Lincoln confronted a great internal rebellion and Roosevelt stood eye to eye with Hitler. Neither Lincoln nor Roosevelt, nor for that matter any other President, had pretended to be exercising routine powers of the President. Nixon, and to a lesser degree Johnson, had surpassed all the previous residents of the White House in claiming that inherent and exclusive presidential authority, unaccompanied by emergencies threatening the life of the nation, unaccompanied by the authorization of Congress or the blessing of an

130. William P. Rogers, "Congress, the President, and the War Powers," California Law Review, Vol. 59, No. 9 (September 1971),p. 1200. 
international organization, permitted a President to order troops into battle at his unilateral pleasure.

There is a distinct difference between the theory of war making as applied by Johnson and Nixon. Johnson's theory, while more sweeping in principle, was more confined in practice. Johnson based his actions on threats of national security. Nixon, when moving large numbers of troops into Cambodia, presumably based his action on a potential attack on American forces. Also, Johnson's actions were restricted to a country with which the United States was in a state of de facto war. He had rejected recommendations from his military leaders that he carry the war into the neutral state of Cambodia on a large scale.

In expanding the war into the states of Cambodia and Laos, Nixon cited no emergency that denied time for congressional action, expressed no doubt about the legality of his personal extension of the war into the two nations, and showed no interest even in retrospective congressional ratifications. The authority claimed by Nixon appeared beyond repose so long as a President could declare American forces anywhere in the world in danger of attack.

This troop-protection doctrine of the administration was short-lived, however; for in 1973, after the withdrawal of troops from Vietnam, the administration began heavy bombing of Cambodia and implied at the same time that the bombing of Vietnam could be renewed at any time it was necessary. The administration justified this action by referring to the Lon Nol regime as an ally which had requested aid in combatting communism. The classifying of Cambodia as an ally at this time seemed a great joke to anyone who had followed Cambodian politics in the 60's and early 70's. First, Cambodia had long before the 1973 bombing rejected any claim of protection under SEATO. Moreover, Congress itself had prohibited the sending of American advisers or ground troops 
into Cambodia and had stipulated that other forms of aid to Cambodia could "not be construed as a commitment by the United States to Cambodia for its defense." 131

This background understood, the defense of Cambodia as an ally became very puzzling to some members of Congress. One who raised the issue was Senator George McGovern. In Senate testimony McGovern commented that it was "a fascinating question of law how a country which has refused protection under a treaty, a country whose defense by the United States is prohibited by law, none the less qualifies as an ally." McGovern continued that the Cambodian government must be more than an ally, since it appeared that Lon Nol's request for American air strikes gave the President authority to mount those strikes. The Senator concluded that the Lon Nol regime would therefore seem a kind of super-ally, with an active role, superseding that of Congress in our constitutional processes. $^{132}$

Whether the action was in Vietnam, Cambodia, Laos or the like; the Nixon theory of presidential war had effectively liquidated what was left of the constitutional command that the power to authorize war belonged to Congress. Nixon had thereby erased the most solemn written check on presidential war; if not the most striking check on power within the entire Constitution. He had not confessed to the slightest misgiving about the legality of his course. Even Lyndon Johnson, while expanding war sought to keep it localized. Nixon had aimed to establish as normal presidential power what previous Presidents had regarded as power justified only by extreme emergencies and employable only at their own peril.

131. Supplementary Foreign Assistance Act of 1970, Sec. 6.

132. Congressional Record, Vol. 119, Part 13, 93rd Cong., 1st Sess. (May 17, 1973), pp. 16140-16142. 
The Congress' central role in foreign affairs as a whole, under the Nixon administration, was to provide aid and comfort to the commander in chief. He never sought the advice of Congress before major initiatives and acknowledged its existence only after policy was totally formulated and implemented. Any public questioning of administration policy by members of Congress was considered taboo. The attitude expressed by Dean Rusk in 1967 still applied during the Nixon years; maybe this view was even stronger. Rusk, speaking of congressional debate on the war, stated that "debate on Vietnam tends to encourage Hanoi and it offers no alternatives that the administration has not considered." 133 This was an extremely broad assumption to make in 1967 and remained so throughout Richard Nixon's term in office.

The role which Gerald R. Ford played in this evolutional cycle of the presidential war making scheme was fairly short. His only action which appears applicable here would be his treatment of the Mayaguez incident of 1975 . This action will be studied later and the role of President Ford will be more appropriate at that time.

For now, if it can be assumed that the President does have dominant control of the power to make war at his discretion, the next logical step is to try and understand how this imbalance took place. Are there actual factors that might justify this ascendency and has Congress fought to keep the power which the Constitution originally gave it?

133. Marvin Kalb, "Doves, Hawks and Flutters in the Foreign Relations Committee," The New York Times Magazine, November 19, 1967, p. 72. 


\section{A Dominating President: Who is to Blame?}

There are numerous factors responsible for the rapid growth of executive war powers during the twentieth century. There are also a number of factors which have decreased the role of Congress.

The single factor which may have contributed more to the imbalance than any other source must be the emergence of the United States as a world power with the resulting alteration of the nation's security posture and its conception of what is required for defense. The belief that American security is closely related to that of many other nations and that the United States must therefore defend pledges to these nations has led to an emphasis on leadership which is constantly prepared to act quickly and flexibly. Decisions which might involve the engagement of American forces receive additional importance when one realizes that since the advent of the 20th century the United States has possessed a standing Army which is sufficiently large, sufficiently well-equipped, and sufficiently mobile to make possible, through presidential action alone and on short notice, conflicts of unforeseeable dimensions anywhere in the world. ${ }^{134}$ Granted, a military establishment of this size must be given clear and concise orders if it is to be effective, but the building of a large force such as this should also lend increased significance to the constitutional concern for the application of use of this force.

134. In 1789, when the Department of War was established, the number of military personnel on active duty totalled 718 . By 1812 it had reached over 12,000. During the 19th century with the exception of the years during and immediately following the Civil War, the total never significantly exceeded 50,000 until the Spanish-American War in 1898. It then increased to 200,000. For twenty years following WWI the average remained between 250,000 and 300,000 , After reaching a WWII peak of 12.1 million in 1945, the total has remained at approximately 3 million.

"Congress, the President, and the Power to Commit Forces to Combat," Harvard Law Review Vol. 81, No. 8 (June 1968), p. 636. 
W. Taylor Reveley feels Congress is "too uninformed, and inexpert, too indecisive and inflexible, overly public, almost always too slow and sometimes out of session when crises arise." ${ }^{135}$ To the contrary, Ambassador John Kenneth Galbraith has stated that "Over the last half-decade Fulbright, Morse, Gruening, Kennedy, Cooper, Church, Hatfield and McGovern have surely been more sensible than the senior officials of the Department of State. On the average I think we are safer if we keep foreign policy under the influence of men who must be reelected." 136

Finally, the executive branch of government did not establish America's position single-handedly and the military system which is employed today was a joint venture by both the Congress and the White House, so why should its application to the current environment be so absolutely restricted to the presidency?

A second factor which has enhanced the role of the executive in formulating war powers without the assistance of Congress has been the revolution in technological development, especially in the field of nuclear weaponry. The fear of nuclear war and the importance of avoidance have engendered a sense of need to be able to take prompt, decisive action. This action, one is led to believe, must be decided upon and acted upon in the shortest amount of time possible and only the executive can make this decision. To date America has not reached the point of no return regarding a nuclear weapons exchange with our adversaries so a practical excercise involving this philosophy has not occurred. Interestingly enough, one of the great advocates of a strong

135. Reveley, "Presidential War-Making: Constitutional Prerogative or Usurpation?," p. 1293.

136. John Kenneth Galbraith, Book Reviews: George Kennan Memoirs 1950-1963 Vol. II, The New York Times, October 8, 1972, p. 12. 
executive regarding the power to make war has been former Secretary of State William Rogers. Rogers, when discussing a nuclear confrontation, sees the President as having absolute authority; yet he offers Congress a role in the beginning of a skirmish which might evolve into serious conflict. ${ }^{137}$ This seems like a great paradox to the role played by Rogers during the early Nixon years when he sought to keep the legislative branch out of the Vietnam War.

No matter what a Secretary of States may profess when appearing before the very body which has had its powers reduced, the point of the matter is that the age of nuclear weapons changed the balance of power in the roles different institutions play while going to war. Until very recently this process was not seen as an usurpation of any power by the executive. Rather, it appeared the inevitable conclusion imposed on the American government by the age of nuclear power. Richard Neustadt went so far as to say that the standards which established the combined powers to make war in the Constitution could not work in the nuclear age. Speaking before a Senate committee in 1963 he told the gathering that "When it comes to action risking war, technology has modified the Constitution."138

137. Appearing before the House Subcommittee on National Security Policy and Scientific Developments Secretary Rogers stated that "the fact that even a minor skirmish could lead to a confrontation of the major powers and raise the specter of nuclear war, serves to emphasize the desirability of appropriate congressional participation in decisions which risk involving the United States in hostilities,"

Hearings before the House Committee on International Relations, "Background Information on the Use of U.S. Armed Forces in Foreign Countries 1975 Revised," 94th Cong., 1st Sess., p. 129 (1975).

138. Hearings before the Subcommittee on National Scurity, Staffing and Operations, Senate Goverment Operations Committee, 88th Cong., 1st Sess., p. 77 (1963). 
Another element which has had its impact felt throughout the relationships between Presidents and Congresses are the many institutional advantages which make the presidency a natural focus for governmental power, especially during times of rapid change, complexity, and crisis. These advantages stem largely from the fact that the President, unlike Congress, is one rather than many. As a single man, always on the job, he is able to move secretly when the need arises and to combine rapid, decisive action with the flexibility in policy demanded by quickly changing developments.

This singularity facilitates long-range planning. Because he is at the center of an unsurpassed information network and because he is assisted by countless experts, the possibility exists that a decision made by him will include more variables than a decision which might come from Capital Hill. Whereas the Congress has to rely on what it gets from the White House or from the various newspapers, the President daily receives a flood of authoritative intelligence from his diplomatic, military, and economic experts all over the world. As the recognized spokesperson for the country, the President also receives any important communications with foreign leadership. There are times when even the White House is uninformed about events.

It is often argued that this monopoly on expertise, communication, and secret intelligence gives the President the power to initiate military force in combat, because these conflicts require expert knowledge and because the President has access to the required secret information which would assure a successful campaign. This has been exaggerated to a great deal, as is clearly evident in the Bay of Pigs, Dominican Republic, and Vietnam situations. The Cuban Missile Crisis may fit the prescribed guidelines for presidential initiation but it is the exception and not the rule. Slower action, in particular, and more intelligence might have been beneficial when considering the policy for this 
country to follow. Claims that the President, because of his monopoly on intelligence, may move about the world intervening as he wishes have no foundation.

Why must this monopoly of facts exist? Insofar as secret knowledge is concerned, the executive can make such knowledge available to Congress in closed hearings. Nothing is more destructive to democratic institutional life than to have one institution with the power to conceal information which can threaten the very existence of that democracy. Expertise can be handled in a like manner. The Congress has committees and staff members who may be just as capable or more capable of divesting information critical to American policy as those residing in the executive branch of government. It is not as though the President alone has access to secret information and the White House is certainly not beyond leaks.

An avenue which has been increasingly used in recent years to justify the initiation of hostilities by an executive is the power of the President under treaties which this nation concludes with other countries. Members of the executive branch and its backers have claimed that because the United States has entered into defensive treaties with many nations, the President may commit the nation to war in order to carry out its treaty obligations. Stipulations within treaties which pertain to the actual engaging of U.S. troops usually include the phrase "under constitutional process." In looking at the Vietnam War it seems correct to assume that the executive branch of government in the United States interprets this phrase to mean that the President, in his sole discretion, shall decide whether to fight a war or not. ${ }^{139}$

139. This concept of presidential determination of when war is to be initiated is abundantly clear in looking at State Department justification of the Vietnam War. For instance, the State Department Legal Adviser in using the SEATO treaty as justification for President Johnson's action in Vietnam states that "under our Constitution it is the President who must decide when an (contd.) 
The legitimacy of this contention is immediately open for attack. A treaty cannot override the Constitution and under the Constitution it has been established that it is the Congress, not the President, which is to declare war. Thus, it is the Congress which must decide whether particular treaty obligations require entry into war. Therefore the words "under constitutional process," when inserted within a treaty, must mean that the Congress shall make this decision. Neither can it be argued that, because the Senate approves treaties, the Senate has delegated the power to declare war to the President. Another argument forwarded by theorist of this collective security concept of war power authorization by the executive is that for the President not to respond to treaty obligations would reduce American credibility for future crisis. Still, can credibility outweigh constitutionality? Also, why does no one in the executive branch discuss the loss of credibility as a result of Vietnam and Cambodia?

With the understanding that the executive must formulate treaties with the advice and consent of the Senate according to the Constitution, the rise in the usage of executive agreements has lent breadth to the claim by many that the concept of treaties may be outdated. The executive agreement is one of the mysteries of the Constitution. There is no clear interpretation of what this type of agreement is within the Constitution. However, Schlesinger gives it constitutional warrant by stating that this authority lies in a distinction, "drawn but not defined in Article I, section 10, between treaties, which states of the

139. (contd.) armed attack has occurred. He also has the constitutional responsibility for determining what measures of defense are requird when the peace and safety of the United States are endangered." This legal brief did not concern only defensive action, quite to the contrary, it goes on to state that "If he considers that deployment of U.S. forces to South Vietnam is required, and that military measures against the source of Communist aggression in North Vietnam are necessary, he is constitutionally empowered to take those measures." Leonard Meeker, "The Legality of United States Participation in the Defense of Vietnam," Department of State Bulletin No. 54, (1966), pp. 11011102. 
union were forbidden to make, and agreements or compacts, which they could make with the consent of Congress." 140

Gradually this process, which amounted to getting around the ratification of Congress to the interaction between nations under treaty terms, increased in its frequency of use. As this usage quickened, three types of agreements developed. Those made pursuant to existing treaties involved no challenge to Congress, nor did those that had prior or subsequent legislative authorization. But there was a third category which attacked the very nature of the separation of power in the critical area. These were agreements made by Presidents in areas where they possessed constitutional authority to act without consent of Congress. Thus the President, as organ of foreign relations, could recognize foreign governments and settle foreign claims without congressional intervention. Likewise, as commander in chief he could arrange cease-fire or armistice agreements. He could in addition make what were not quite agreements but rather unilateral commitments on the order of the Monroe Doctrine. It might be useful here to look briefly at the standard set by the Monroe Doctrine. Rather than allowing, through this commitment, widespread executive usurpation of the role of Congress, this doctrine had limitations. Although it has been used to justify presidential actions many times within the Western Hemisphere, it would probably be helpful to quote a statement by Monroe made shortly after the adoption of the doctrine. In 1824, after the establishment of the pact, Colombia asked for protection against France. President Monroe responded that the "executive has no right to compromise the nation in any question of war," and he instructed his Secretary of State, John Quincy Adams, to reply to Colombia that "by the Constitution ... the ultimate 
decision of this question belongs to the Legislative Department." 141 This must show that even in the case of an unilateral commitment by a President which would exceed the power of an executive agreement, there was a role for the Congress in the initial establishment of such arrangements.

Some people have suggested that the President can initiate conflict by the power vested in him to take care that the laws be faithfully executed. This argument reverts back to what was said about treaties. It would have it that the presidential power includes the use of force to see that treaties are implemented. As has been pointed out, the President does not have the power to execute treaties by, in effect, declaring war.

Constitutionalists have run into the argument that the President can order forces into conflict because he is supreme in the field of foreign affairs. This is to say that, if he felt war was necessary, he could proceed to fight it. True, the Constitution makes the President supreme in foreign affairs, but that same Constitution makes Congress supreme in the matter of declaring war. This argument of the executive branch regarding foreign superiority may be overstated. Congress has many constitutional powers which enable it to play a significant role in foreign affairs. It must pass the statutes upon which many important foreign policies depend. For example, laws providing assistance to foreign nations. It must appropriate money without which executive policies cannot be carried out. It has the power to pass laws, such as tariffs and various taxes, which vitally affect various foreign policies. A full listing of the many congressional powers which give Congress an important voice in the conduct of foreign relations would have to include the powers to tax and spend, to establish

141. Raoul Berger, "War-Making by the President," University of Pennsylvania Law Review, Vol. 121, No. 29 (1972), pp. 62-63. 
duties, to provide for common defense and general welfare, to borrow money, to regulate foreign commerce, to regulate the value of money, to define and punish piracies and offenses against international law, to declare war, to raise armies and navies, to establish rules for the armed forces, to regulate immigration, and to make laws necessary to carry out all the above mentioned. There is also a role for the Senate in the treaty process. Congress must consider and pass judgment on presidential appointments to the many ambassadors this nation employs. In summary, not only is it untrue that executive dominance in foreign affairs gives the executive the power to override the Constitution and declare war, but it is also untrue that Congress does not have an important role to play in foreign affairs and many ways to defend itself if it has the will.

The concept of limited war has also been used as a devise for furthering the power of the President to make war. Within the framework, critics of congressional participation in the making of war state that today's world must allow for the President to initiate limited war for limited objectives. They go on to imply that a declaration of war under these limited circumstances might mislead other nations as to United States objectives and thus provide a grounds for undesirable consequences. But who is to say that Congress cannot participate in a limited exchange between nations from the start? In a case rising out of the limited naval war with France early in this nation's history (action was authorized by the Congress), Justice John Marshall, speaking for the entire court, said that Congress has the power to declare either a general war or a limited war. ${ }^{142}$ This should clear the air of the contention that if Congress does not want to declare war then it is out of the picture as far as the initiation

142. In Talbot v. Seeman, Marshall concluded that "the whole powers of war being, by the Constitution of the United States, vested in congress the congress may authorize general hostilities or partial war." 5 U.S. (1 Cr) 1, 25 (1801). 
of conflict is concerned. Congress can and should have a role in any type of war, limited or general. And if declarations of war have become outmoded, this does not require that Congress' role ends here. Most localized war should be left alone by the United States. Being particularly clear after Vietnam, no hostilities these days can be very limited. All conflict today can be put into some world influencing power structure and these conflicts have a nasty habit of escalating.

Another of the continuing arguments for Presidential war making powers is that most wars in which the United States has participated have commenced before Congress formally declared war and have occurred because of predesigned presidential military policy. It may be true that sometimes, as in the Second World War, hostilities commenced before a congressional declaration of war. These circumstances do not mean that the President can carry on hostilities for an indefinite period of time without a declaration of war. One must add that only five times has Congress saw fit to declare war. Part of the reason for this apparent neglect by Congress is this idea of a "fait accompli" or inevitability concept which controls entirely too much of the thinking within Congress itself.

Finally, a weak assumption is that many actions taken in America's history were done so by the President in order to preserve American lives and property during unstable situations or to punish pirates, bandits, or cattle thieves. Such action is justified under the presidential power to repel attacks on American citizens and property, but this does not amount to an act of war which could be considered analogous to the Korean conflict or Vietnam intervention.

A number of other developments have surfaced within this nation to give additional impetus to the President's unconstitutional authority to initiate war. For instance, the growing ability of the government to communicate directly with the governed has to be considered an advantage. Radio, motion pictures, 
and television put the President squarely in view of the public every night of the week. Thus, as a single rather than a collective decision maker, the President provides an easy target for the public and the media to follow. As the elected head of the state he commands attention. The public and the media find it much easier to concentrate their attention on this one person than on the 535 members of Congress. Many members of a community do not even know who their elected officials are. The resulting acceptance of leadership from the White House rather than from the Congress is an understandable result.

One final word might be added about the role of party politics and the position held by the executive regarding war powers: While the party system has made the process of electing the president increasingly democratic, it has done little to facilitate decisive action by the legislators and has left them exposed to the play of special interests. ${ }^{143}$ The President rather than Congress has come to be seen as the symbol of national unity and in turn the guardian of national security. Consequently, the capture of the presidency has become the primary objective of American politics and Congress has become, for some, nothing more than a proving ground for future presidential aspirants.

With residence in the White House becoming the number one goal of America's political community, and with this view shared by the general public of the nation, it is easy to see Presidents moving into the high office with a greater willingness than Congresses, to exercise their constitutional powers to the fullest and to go beyond, for that matter, with less fear. As a President reaches beyond the imaginary line between the powers of the executive and those of Congress, and gets away with it, a momentum takes over. With each

143. Clinton Rossiter, Parties and Politics in America (Ithaca, New York: Cornell University Press, 196), Pp. 60-62. 
new function the President has assumed, with each crisis that he has met, with each corresponding rise in his prestige, in popular expectations, in presidential folklore and myth, the office has become more potent.

Of the many arguments and advantages put forward so far, none actually give the President a valid constitutional basis for conducting an hostility from its inception unless unconstitutional precedents eventually legitimize these wrongs. Indeed, it is not too much to say that if the executive has the power which so many have concluded, then the clause giving Congress the power to declare war is as good as gone from the Constitution.

What then has happened to the role of Congress as the executive has gone about assuming these new powers described above? As presidential power increases, the decline of congressional influence can be seen. Although Congress remains a powerful body, far more so than the legislative bodies of any other sizable nation, the times in which it was able to assert itself in foreign affairs and specifically in war powers may have passed. The existence of two equal houses, both vying for power over the other, militated against its ever being able to assert complete supremacy, thereby allowing the executive to gain power almost without trying. And generally, unlike the institutional characteristics of the presidency, those of Congress have not attracted power during times of rapid change, complexity, and crisis. To the contrary, these stimulants to executive power have served as retardants to congressional power.

Much of Congress's present eclipse, however, stems not only from action by the executive branch of government, but also from its own unwillingness to act. The loss of power by Congress can be measured by the extent to which congressional assertion coincides with congressional hesitance. This paradox has been at the root of the problem since the early days of this nation. Samuel P. Huntington puts this in proper perspective when he states that "Vis-a-vis the 
Executive, Congress is an autonomous, legislative body. But apparently Congress can defend its autonomy only by refusing to legislate, and it can legislate only by surrendering its autonomy." 144 This appears to be a rehashing of the "fait accompli" argument mentioned above; however, one can not just stop here and say that because of this factor Congress cannot have the powers entrusted to it by the Constitution. The position which the executive occupies today in the American political sphere adds fuel to this great paradox. If Congress legislates, it subordinates itself to the President; if it refuses to legislate, it alienates itself from public opinion which is dominated by the executive. Congress can assert its power or it can pass laws; but it cannot do both. Often legislative action is a direct contradiction to presidential action.

Congress has played a major role in the demise of its war powers. In the lengthy debate concerning the national commitments in 1969, the Congress admitted as much when its report included the following passage:

The committee is well aware -- and has expressed its awareness several times in these pages -- that one of the reasons for the flow of the war powers out of the hands of Congress and into the hands of the President has been the failure of Congress to adapt its power over the armed forces to the circumstances of the nuclear age. Tacitly acknowledging a lack of confidence in its ability to make that adaption, Congress has permitted its war power to be transferred to the hands of an executive which, though less susceptible to self-doubt than the Congress, is no less susceptible to error. 145

What factors have lead to this collapse? Until this century, broadly speaking, the President was the administrator, while Congress was both the innovator and legislator; however, there has, indeed, been a shift in this balance.

144. Samuel P. Huntington, "Congressional Response to the Twentieth Century," in The Congress and America's Future, ed. by David B. Truman (New Jersey:Prentice-Hall, 1965), p. 6.

145. Hearings before the Committee on Foreign Relations, United States Senate, "National Commitments," 90th Cong., 1st Sess., p. 26 (1967). 
Many critics of the Congress conclude that the rise of the executive at the expense of the legislative branch has been totally the fault of Capitol Hill. Failure to act has been the most common outcry of these critics. Arthur Schlesinger has written in Foreign Affairs that "Its complaints have been eloquent; its practical action has been slight. Its problem has been less lack of power than lack of will to use the powers it has." 146 Looking at the history of this imbalance a self-destructing element surfaces. Like the great salmon returning to the stream of its hatching to face certain death; Congress, through history, has moved up a legislative stream that can only end in its death as a real force in the political process of war.

Elective government has had a tremendous impact on Congress. This democratization of politics surfaced to cope with or eliminate government dominated by large financial and industrial interests. This reform was aimed at the creation of a more responsive government. Action at the federal level included the direct election of Senators (result of the 17th amendment to the Constitution) and the dispersion of House Speaker Joseph Cannon's control over the Rules Committee of the House of Representatives.

Ironically, these reforms did not have the same impact on Congress as democratiation had on the presidency. Instead of increasing the power and prestige of that branch, it removed a potential source of internal leadership, which might have aided congressional policy formulation and review. Hence, while the President was becoming the political, governmental and popular leader of the United States, the Congress was having its leadership dispersed just when it was needed to keep pace with that being set by the executive. p. 104.

146. Schlesinger, "Congress and the Making of American Foreign Policy," 
There were other factors to consider in the downfall of Congress not only in war powers but in the overall view of military policy. First, the increase in the volume and complexity of legislation, which must be considered when reviewing the military and foreign policy and its financing, tends to tie the hands of Congress. Detailed economic programs for foreign aid and weapons systems have overburdened congressional facilities, which in turn allow for appropriations of programs which members of Congress know little about.

Because of this complexity of legislation dealing with national defense, congressional committees have focused on those areas in which they felt most comfortable and competent. Members of the relevant committees seem to be infested with a disease of information. Rather than strive for more data concerning a specific policy, they tend to lay low until the answer is obvious. In a study done in 1965 by Lewis Anthony Dexter which included interviewing nearly a hundred members of Congress, the conclusion was drawn that members of Congress do not want to know the military's specific plans for national defense. In fact, says Dexter, "they are not at all concerned with the nature of the war plans." 147 It would seem that, as members of Congress, they would be afraid of inhibition or embarrassment by having access to more confidential security information than they desire to know. They do not have to raise any alternative plans since they do not concern themselves with the administration's plans. At the same time they are not diplomatically, politically, or militarily responsible for events.

147. Lewis Anthony Dexter, "Congressmen and the Making of Military Policy," in Components of Defense Policy, ed. by Davis B. Bobrow (New York:Rand McNally, 1971), p. 101. 
The military exercises a monopoly on presentation of alternatives, with the result that congressmen have no reason to be aware of the scope of possibilities open to them. When the military determines the explanations they hear, and the choices they are forced to make, congressmen have little opportunity to move into an area of reflection broader than that of the military. Because of these built in congressional limitations, there are few effective ways in which the legislative body can provide a clear evaluation of a plan or policy. The Pentagon can and does lobby congress, as Dexter concludes the military can be very corrupt. Says Dexter, "the people who are really trying to bribe and pressure Congress are from the Department of Defense." 148

One particularly appropriate means of evaluating programs, if alternatives could be forwarded, might be a better cost-effectiveness study in Congress on various military programs. Congress, however, has not developed sufficient computerized facilities or the necessary staff to make the transition from mere auditing to cost-effectiveness analysis. In fact, according to a study made by the Boston University Law Review in 1970, "the General Accounting Office has not progressed much beyond its original auditing function of 1921."149 The reason that the date 1921 has been used here is that this was the year Congress passed the Budget and Accounting Act. Prior to 1921 Congress has the primary obligation for preparing the national budget. The responsibility for drafting budgetary proposals and appropriations bills had been scattered throughout congressional committees. The reform in 1921 transferred primary responsibility for budget preparation from the legislative branch to the executive

148. Ibid., p. 106.

149. Henry P. Honaghan, "Presidential War-Making," Boston University Law Review, Vol. 50, Special Issue (Spring, 1970), pp. 57-58. 
branch through the creation of the Bureau of the Budget. This resulted in a more comprehensive approach to assembling and correlating requests from the executive departments and agencies. In reality, however, this act meant that the President could exert stronger control over the legislative mechanism by selecting the fiscal information, drafting a budget suitable to his policies, and locking congressional review of the budgetary proposals within the scope of the executive's own programs. Even the Congressional Budget and Impoundment Act of 1974 (Public Law 93-344) has failed to establish Congress as an equal partner. The act sought to unify the budgetary process; however, the annual budget is still the President's recommendation and seldom is Congress able to muster enough support to challenge. Thus the President both proposes and administers the budget while Congress merely reviews both functions. Again, the selfdestruction theory is a factor of monumental importance which contributes to congressional inaction and ineffectiveness.

The size of the executive branch of government has mushroomed and congressional facilities have not kept pace. Employees under the executive greatly outnumber those in the legislative branch. Institutions like the military establishment, the State Department, and the Central Intelligence Agency are so large, involve so many programs, and are so dispersed throughout the world, that the limited time, energy, and staffs of congressmen cannot meet the burdens associated with overseeing executive operations. The Defense Department alone has an annual budget of nearly two hundred billion dollars and nearly one million active military personnel, not to mention millions of civilian personnel, which Congress must somehow keep an eye on. A quick look at past military action around the globe shows us that this mission is impossible under current congressional standards. 
The result of this gross imbalance in size is that a congressional committee such as the House Armed Services cannot muster the resources to effectively challenge the proposals, statements, information, and analyses of the executive. Often these committees become nothing more than audiences for presentation of charts, movies, lectures, and guided tours of programs which the individual members know nothing of and which provide nothing to clear up their uncertainties.

Another consequence of the growth of the executive has been that pinpointing responsibility for administrative decisions has become difficult, if not impossible. Decision making responsibility for military and foreign policy determinations must be traced through the White House and various boards and committees dealing with the national security, the State Department or the Pentagon, and eventually to the three major services. Where responsibility cannot be located, the congressional functions of supervision and investigation cannot be fulfilled. Without being able to provide these two very important functions, congressional consideration of legislative programs concerning national security deteriorates to a process in which the most important part of consideration becomes not the broad general policy of a program but rather what the particular package might do for production within one's state, or how much manpower a program might require or provide.

As mentioned above, today's modern world requires an increase in executive power, as well as a decline in the legislative branch. Large peacetime armies, new weapons systems, the continuing crisis atmosphere which hangs over the world; all have led to the downfall of the Congress. These factors have contributed to the pressure for a unified national strategy to coordinate the resources of the United States. Congress has met these pressures by delegating responsibility to a more cohesive executive. In order to provide the President 
with the broad discretionary powers which he says he must have to be flexible in the ever changing world, Congress has passed legislative acts without specific standards which might require certain presidential action. For instance, from alleged attacks on a U.S. destroyer in the Tonkin Gulf, Congress gave the President the authority to proceed with a large scale war which was totally against the process set forth in the Constitution. Such vaguely-worded resolutions as the Tonkin Resolution do not provide Congress with the necessary frame of reference for the review of executive performance. Moreover, when an enactment is so vague that few congressmen can agree on the scope and meaning of the authorization given, any restraint on the President is minimal.

As America's role in the post-war era expanded, one would have expected an expansion of Congress' role as well. In particular, congressional oversight should have been enlarged in direct proportion to the expansion within the White House. Not so, however. Louise Fisher has stated that Congress has at its disposal "a number of methods for overseeing the operations of administrative agencies." 150 All these methods can only be successful if adequate information is made available by the various agencies. Legislators must acquire more than just the information that the executive branch wishes them to have. The courts (McGrain v. Dougherty) have recognized the right to gain information from the public institutions which would be needed to legislate. ${ }^{151}$ This necessary access has been prevented by the arbitrary and unrestricted use of the doctrine of "executive privilege." The basic meaning of the doctrine is that only the

150. Louis Fisher, President and Congress: Power and Policy, (New York: Free Press, 1972), p. 81.

152. In 1927 the federal court, in McGrain v. Dougherty, held that a legislative body could not legislate wisely or effectively in the absence of information respecting those areas that are the responsibility of Congress. 
executive has the power to decide what information in its possession should be released. President Eisenhower in 1954 writing to his Secretary of Defense on this matter stated, "Throughout our history the President has withheld information whenever he found that what was sought was confidential or its disclosure would be incompatible with the public interest or jeopardize the safety of the nation." 152 It was not until 1974 that the judiciary looked at the executive privilege doctrine. In the United States v. Nixon the Supreme Court found the legal means by which the president and his staff could be denied executive privilege. The court unanimously ordered President Nixon to release recorded tapes that had criminal information on them.

The Constitution does not include any specific reference to the executive's privilege to withhold information; however, Congress has rubber stamped this action many times. If the earlier assumption that much of Congress' problem in relation to the executive lie within Capitol Hill itself, one can see the Congress endorsing the inevitability of executive privilege. For instance, Congress recognized the validity of this privilege in the Mutual Security Act of 1960. A section of this legislation, which because Public Law 86-472, requires that the President certify the refusal, by the executive branch, of a request for a document.

This area is certainly a crucial question within constitutional law; however, it is in this realm of thought that one must recognize that without a clear and unimpeded access to relevant information Congress cannot function as the Constitution was written. There is no question as to the right of the executive to withhold information from the public when release of such information would not be in the national interest. Query here is, who shall

152. William P. Rogers, "Constitutional Law: The Papers of the Executive Branch," American Bar Association Journal, Vol. 44, No. 9 (September 1958), p. 941. 
determine the national interest and who will determine what information is relevant and irrelevant?

Resolution of the problem of congressional access to information will undoubtedly require a compromise between the goals of protecting national security and informing Congress. Generally, compromise can only be attained, and be equitable, when there is an honest evaluation by the parties involved in a situation. All sides must start on even ground. A compromise built along these lines could allow Congress to act within it's areas of responsibility without having to compromise the considerations of national security. Both sides must give and take responsibility.

A study of the fragmented structure of Congress might be in order at this time. Samuel P. Huntington claims that this fragmentation is due to the political atmosphere in which the legislature operates. While Huntington agrees that because Congress is not given access to information, it cannot act in an asserting manner, he places more of the blame on the political failings of Congress. He sees interest groups and pressure groups playing a very formidable role in military programing. Various military programs must be weighed against one another, against conflicting interpretations of the security threats and military requirements, against domestic needs and non-military foreign policy programs, and against probable tax revenue and the demands of fiscal policy. Huntington concludes that "no congressional committee is competent to do this, not because it lacks the technical knowledge, but because it lacks the legal authority and political capability to bring together all these conflicting interests, balance off one against another, and arrive at some sort of compromise or decision." 153

153. Samuel P. Huntington, "Strategic Planning and the Political Process," in Components of Defense Policy, ed. by Davis B. Bobrow (New York:Rand McNally, 1967), p. 82. 
Only the executive has been able to orchestrate the diverse resources at its disposal to produce a coherent military strategy and an all encompassing foreign policy. Congress cannot bring together enough of the political spectrum from the two parties to force an important policy of its own. Without a union of the parties there is little, if any, hope of formulating some type of congressional policy on an issue.

Going beyond the politics of Congress, again we find a stumbling block when considering how Congress actually operates. Congress functions primarily through the work of its committees. House rules require that all substantive legislation originate in committees other than the Appropriations Committee. Thus, all projects ultimately requiring financing go through two stages: an authorization stage and an appropriations stage. The authorization stage for foreign and military matters involves legislative committees such as the two Armed Services Committees, the Senate Foreign Relations Committee, the House International Relations Committee, and the like. Appropriations come mainly from the House and Senate Appropriations Committees. The quality of the evaluation made in these various committees is determined to a large degree by the lack of political cohesion mentioned above.

The subcommittee structure of Congress further fragments the process. Authorization bills are split up among the committees that have jurisdiction over various sections of the bills. Some aspects of the proposals are considered by several committees, with no communication between them. Because these committees work in isolation from one another, the overall policy objective of the United States is obscured. Of the two bodies which constitute the Congress, the Senate may offer a better chance for alternatives to executive foreign policy. While separate issues are considered by separate committees in the Senate, much as they are in the House, there are a number of factors which tend 
to offer more hope. Above all, with a smaller size to the body and greater prestige, the upper chamber has devised some techniques for intercommittee cooperation. Joint hearings between committees in the Senate are more common than in the House. There is an overlapping of committee assignments in the Senate to a degree unknown in the House and this tends to diminish provincialism. The professional staff is much more important in the Senate simply because of its size. The staff people sometimes called "shadow lawmakers or surrogate senators" of ten draft and interpret legislation totally.

Two factors contribute to this uncooperative nature of the chambers. First, the House units are over protective of their prerogatives, especially their power of the purse. Secondly, the constituencies of each member of the House is quite different from those of each Senator.

The conference committee procedure for bills that pass both houses containing dissimlar sections cannot overcome the prior effects of an institutional process that fragments the issues involved. The conference committee may arrive at a better coordinated compromise than could be achieved through the mechanisms in each committee and chamber of the two houses, but the process is still informal and unsystematic. Also, the conference committee cannot effectively deal with underlying fiscal policy or issues crossing the jurisdiction of other conference committees. The fragmentation that occurs prevents Congress from asserting control over the budget based on policy rationales; thus, the policy-setting initiative passes to the more cohesive executive office.

Finally, parochialism must be considered a problem. The scale by which members of both chambers determine their power and prestige is built around such considerations as degree of individual independence, specialization and expertise, and the stature of various committees. Increasing the degree of 
coordination among committees in one chamber and then increasing communication between committees of the two houses of Congress would entail some loss of individual and committee independence. While this coordination may be the only way to obtain a more effective role for Congress in the area of war powers and foreign affairs in general, the big game being played is the reelection contest and one must preserve his individual power in the eyes of the folks back home in order to survive periodic November showdowns.

It is very important to gain a clear perspective of how the power of appropriations can affect not only the power to make war but also the entire area of foreign affairs. This is one particular segment of the Constitution which was totally reserved for the legislative branch of government. Under Article I the Congress has the power to raise and support armies, to provide and maintain naval forces, to make rules for the regulation of the land and naval forces, to provide for the calling forth of the militia and to provide for organizing, arming, and disciplining the militia. This would seem at first glance to give the Congress a fair handle on the military of this nation under peaceful conditions. Add the power to declare war and you have a program which leaves little room for executive interruption unless a condition of declared war exists.

With this exclusive power in mind, and reflecting on how the President has increased his power, who is to say that the Congress cannot do the same in an attempt to retrieve its lost power? Defenders of presidential war and other foreign policy absolutism have maintained that the Constitution at different times has given the executive his power in these areas. Congress has the ability to appropriately bring this imbalance back into line.

There is no question that the appropriations power, if properly used, could be a powerful means of asserting pressure on the executive. Clinton Rossiter claims that "no great policy, domestic or foreign, can be maintained effectively 
by a President without the approval of Congress in the form of laws and money." 154 No major military action like that in Korea or Indo-china could have occurred without extensive funding from the Congress. This is not to say that by appropriation of funds for an action Congress has set forth a policy which they cannot reverse. During the Vietnam War a major argument provided by the administrations of Lyndon Johnson and Richard Nixon suggested that once appropriations were provided this action would bind Congress to continue its policy. Not so. The taxing power is committed to Congress alone, and no moneys from the United States Treasury may be spent except as authorized by law. Thus, appropriations power is plenary, and unless Congress is bound by a previous authorization or ratification of a particular policy, it could refuse to support a foreign military commitment. Whether the commitment has already been initiated or is in the planning stage would not be a determining factor.

Thus, Congress could use its power of appropriations to determine foreign policy or war. However, the practical implementation of this power may be difficult. The maximum amount of control would be achieved by detailing the uses to which appropriated money could be put. While this seems easy at a glance, the same difficulties which have led to the decline of legislative power in other areas have an impact here. The very breadth of the defense budget makes it impossible for the Congress to consider each individual monetary request. The feeling in Congress that the White House must have some latitude in its policy formulating presents built-in roadblocks in this area.

Another device the executive has occasionally employed to frustrate Congress in the formulation of military policy through appropriation has been impoundment. Using this technique the executive may impound funds that 1960), p. 54.

154. Clinton Rossiter, The American Presidency (New York:Harcourt, 
Congress has appropriated for a particular project if the executive considers it to be unwise, wasteful, or inexpedient. The outcry over impoundment has been extremely loud over the years; however, by 1970 Congress had expressly given this power to the executive in the field of foreign affairs. ${ }^{155}$ This action, which was part of the Defense Department Appropriations Act of 1970, may have signaled the end to any justification for this upheaval. It appears that Congress is again its worst enemy vis-a-vis the executive within the field of foreign affairs. The Congressional Budget and Impoundment Act of 1974 did limit this activity by executives but only because it has not been challenged.

Of course, the ability to transfer money between departments and between projects within a department is an example of executive flexibility. In spite of the general provision that moneys may be used only for the purpose for which they were appropriated and for no others, transfer authority has been granted to the Department of Defense. ${ }^{156}$ This condition is aggravated by the fact that certain apportionments or reapportionments may create the need for supplemental appropriations. If the transfer statutes alone were involved, the restrictions imposed on such transfers could prevent the funding of any large scale projects not authorized by Congress. However, the availability of transfer authority becomes more significant when coupled with contract authority and

155. Section 613(a) of the Defense Department Appropriations Act of 1970 stated that "during the current fiscal year, the President may exempt appropriations, funds, and contract authorizations available for military functions under the Department of Defense, from the provisions of the act, whenever he considers such action to be necessary in the interest of national defense.

156. 31 United States Code, section 697 of 1964 states that "Any appropriations to any department, agency, or corporation in the executive branch of the Government for salaries and expenses, shall be available for the discharge of responsibilities, relating to the national defense, assigned to such department, agency, or corporation, and transfers may be made between appropriations or allocations within any such department, agency, or corporation as may be necessary to carry out this proviso. 
emergency spending powers. Congress, in recognition of the limitations on the budgeting process, has earmarked certain funds to be used in emergencies, or for needs that may arise when Congress is not in session. An even more important factor in undermining congressional control over the military is the authority of the executive to expand the size of the military and thereby create an unlimited obligation against the government which Congress cannot overlook. ${ }^{157}$

There are undoubtedly many other devices that allow the executive departments generally, and the departments involved specifically in defense and security, to increase their control over the amount of funds available and the purposes for which these funds may be spent. One method that has surfaced in very recent years in connection with the Central Intelligence Agency is the idea of hidden funds.

However, despite the ability of the executive to frustrate congressional will in a number of ways, it does not appear that any of these devices allow the President to carry on an armed conflict of substantial size without the approval of Congress. A more specific approach to the appropriations process may help. This idea of conditional appropriations has been used with some success; for instance, the so-called Cooper-Church amendment was a very constitutionally sound attempt to restrict military appropriations. 158

157. Section 613(c) of the Department of Defense Appropriations Act of 1970 states that "Upon determination by the President that it is necessary to increase the number of military personnel for active duty beyond the number for which funds are provided in this Act, the Secretary of Defense is authorized to provide for the cost of such increased military personnel." This was not the first time that a clause of this nature was included in appropriations legislation.

158. This now famous amendment surfaced during debate in the 91 st Congress while considering defense funding. The amendment provides that "In order to avoid the involvement of the United States in a wider war in Indochina and expedite the withdrawal of American forces from Vietnam, it is hereby provided that, unless specifically authorized by law hereafter enacted, no funds authorized or appropriated pursuant to this Act or any other law (contd.) 
To answer the question of who is to blame for this constitutional imbalance a two-pronged attack is necessary. First and foremost, it has been by the initiative of the executive that this situation exists. A constant reinterpretation of the Constitution is going on in the executive branch of government. This is not a suddenly arising phenomenon, but one which has existed from the very beginning of this nation. The focal point of the nation is the President and this notion has gripped the legislative branch, as well as the public. Because of this mystique which travels with the executive, the Congress has been more than willing not only to go along with initiatives from the White House which tend to emphasize the imbalance, but to actually offer input which can only increase presidential influence. The self-destructive feature of Congress, when coupled with the expansionistic nature of the executive branch, can offer only a continued and ever increasing imbalance in this critical relationship.

If Congress wishes to exert a stronger influence in war powers and foreign policy in general, the process should begin soon. Since the trend toward executive control over the international commitments of the United States has accelerated in the past decade, any delay will make the task more difficult. Unless the legislative branch is willing to accept a profoundly altered role from that which the framers intended, it must seek to retard and reverse that growing executive hegemony. Since the closing days of the Vietnam War there have been actions taken by the legislative branch to at least slow this process. The Cooper-Church amendment, the Hatfield-McGovern bill, and the War Powers Resolution are the most important actions taken in an attempt to stem the tides. Whether these will work only time will tell.

158. (contd.) may be expended for the purpose of retaining United States ground forces in Cambodia." 


\section{The Restoration of a Constitutional Balance}

Assuming an imbalance exists a restoration of the division of war powers, specified by the Constitution and generally adhered to during more than a century of national experience, is both compatible with modern conditions and essential to constitutional government. Whatever is done either to adjust or confirm the existing relationship between executive and legislative branches in decisions of war and overall foreign policy, it should be done deliberately and in accordance with constitutional procedures. Whether one approves of the present division is immaterial, what must be accepted by all those concerned is that an imbalance does exist and a wholehearted attempt should be made toward removing this from the American governmental process.

Claims to unlimited executive authority over the use of the armed forces of the United States are made on grounds of both legitimacy and necessity. The argument of legitimacy is based on a misreading of both the Constitution and American history. Careful study of the Constitution and of the intent of the framers give the executive the power of repelling sudden attacks on the United States. The founders of our country intended decisions to initiate either general or limited hostilities against foreign countries to be made by the Congress, not by the executive.

The historical study above concludes that the practice of American Presidents for over a century after independence shows scrupulous respect for the authority of the Congress except in a few instances. The only uses of military power that can be said to have legitimately accrued to the executive in the course of the nation's history have been for certain purposes such as 
suppressing piracy and the slave trade, hot pursuit of fugitives; and, as mentioned, response to sudden attack. Only in the present century have Presidents used the armed forces of the United States against foreign governments entirely on their own authority, and only since 1950 have Presidents regarded themselves as having authority to commit the armed forces to fullscale and sustained warfare.

The case for necessity in the exercise of the so-called "inherent" presidential power is hardly less spurious then that for legitimacy. Aside from the contention that only the executive branch has the expertise to deal with foreign policy matters and war, the only claim within this area of thought is that because of the emergency-like atmosphere of today, the executive must have flexibility and speed so as to counteract any move by foreign powers which could gravely threaten the nation's security and survival. There are two fairly clear rebuttals to this assumption. First, a useful distinction can be made between speed and haste. In a number of situations in recent years which were characterized as emergencies, American policy could have profited from brief delays to permit deliberations and consultation with the Congress. 159

The other great flaw in this idea that Congress cannot meet an emergency is that, while there may come a situation which might require immediate action, this does not mean that consultation with Congress should not still be held, even if it is after the fact. Congress has demonstrated on many occasions that it is capable of acting as speedily as the executive. Should the urgency or the need for secrecy be judged so great, however, as to preclude any form of consultation with Congress; the President, as noted many times earlier, has unchallenged

159. For instances, in the case of the Gulf of Tonkin resolution, a delay of a week or two would have permitted Congress to record its intentions in a legislative record; the retaliatory attacks on the North Vietnamese ports had already been made when the resolution was put before Congress, so that a delay would have had no military consequences. 
authority to respond to a sudden attack upon this country. This authority is recognized as nothing less than a duty and it is inconceivable that Congress would fail to support the President in such a case. Finally, should the President find himself confronted with a situation of such complexity and ambiguity as to leave him without guidelines for constitutional action, it would be far better for him to take the action he saw fit without attempting to justify it in advance and leave it to Congress or the courts to evaluate his action in retrospect. A single unconstitutional act, later explained or pronounced unconstitutional, is preferable to an act dressed up in some spurious, precedent-setting claim of legitimacy.

For all of the foregoing reasons, one must reject the contention that the war powers as spelled out in the Constitution are obsolete and strongly recommend that Congress reassert its constitutional authority to have a dominating role in the question of war, as well as regulating and providing for the military. Exactly what the Congress can do to rebound from this situation as it exists today is a very difficult and complex question.

Radical change is not in order. William Fulbright stresses that fundamental changes in our national policy formulation apparatus need not be made. ${ }^{160}$ Any action along this line could and probably would eliminate or substantially modify the separation of powers as it is set forth in the Constitution. Changing the document is not necessary but rather an accurate interpretation of the Constitution as is written.

Focus on the political process as it exists is essential. Continuity with the past is absolute, changes must be made but not at the expense of the political institutions themselves. Radical proposals like the Bricker Amendment of the

160. Fulbright, "American Foreign Policy in the 20th Century under an 18th Century Constitution," p. 12. 
50's or the Ludlow Amendment of $1935^{161}$ are not helpful changes; however, they do offer a clear view that the situation has gotten out of hand. Extreme actions like these were results of the partisanship of the 50's and the isolationism of the 30's. This is not to say that action within the Congress cannot be positive in restoring the constitutional balance.

Suggestions for reestablishment by Congress of a more influential role in the excerise of war powers and foreign policy in general might be divided into three categories: first, that future policy resolutions be deliberated carefully and defined clearly as to the scope of congressional authorization: second, that there be standard procedures enacted for reporting and consultation between the President and the Congress; and finally, that by legislation the circumstancs under which the President might initiate hostilities in the absence of a declaration of war be defined by rule.

The broad and uncertain nature of the powers granted in past resolutions has been noted earlier. Joint resolutions such as those pertaining to Formosa, the Middle East, and the Gulf of Tonkin are a proper method of granting authority, provided they are precise (which these were not) as to what is to be done and for what period of time, and provided that they do in fact grant authority and not merely express approval of undefined action to be taken by the

161. The Bricker Amendment sought to give Congress a voice in foreign treaties. The pervading theme was that treaties and executive agreements should have no domestic standing without internal legislation. This meant that positive action by Congress as a whole, and in many cases by state legislatures as well, would be necessary to put international compacts into effect. The amendment also provided that implementation of this was to be retro-active. The Ludlow Amendment sought to restrict war in this way "Except in the case of attack by armed forces, actual or immediately threatened, upon the United States or its territorial possessions, or by any non-American nation against any country in the Western Hemisphere, the people shall have the sole power, by a national referendum to declare war or engage in warfare overseas. Congress, when it deems a national crisis to exist in conformance with this article, shall by concurrent resolution refer the question to the people." 
President. That distinction is of the greatest importance. As used in the recent past, however, joint resolutions have been instruments of political or potential political control over the Congress in the hands of the President, enabling him to claim support for any action he may choose to take and so phrased as to express congressional acquiescence in the constitutionally unsound contention that the President in his capacity as commander in chief has the authority to commit the country to war. Recommendations for consideration of future resolutions have been made by the Senate Foreign Relations committee. They are as follows:

First, debate the proposed resolution at sufficient length to establish a legislative record showing the intent of Congress; second, use the words authorize or empower or such other language as will leave no doubt that Congress alone has the right to authorize the initiation of war and that, in granting the President authority to use the armed forces, Congress is granting him power that he would not otherwise have; thirdly, state in the resolution as explicitly as possible under the circumstances the kind of military action that is being authorized and the place and purpose of its use; and finally, put a time limit on the resolution, thereby assuring Congress the opportunity to review its decision and extend or terminate the President's authority to use military force. 162

By following these guidelines a recurrence of a Gulf of Tonkin type interpretation by the executive will not occur.

By far, the clearest resolution to date which seeks to express the will of the Congress regarding the war powers problem as it exists today is the so-called War Powers Resolution of 1973 which passed the Congress after a presidential veto. A brief history of the legislative moves to restrain presidential war making might be helpful. Early attempts at passing war powers legislation were

162. Hearings before the Committee on Foreign Relations, United States Senate, "National Commitments," 90th Cong., 1st Sess., p. 26 (1967). 
seen in the months before World War II. ${ }^{163}$ However, the first serious attempt at restricting the war powers of the President were begun as a direct result of the Vietnam War. Disgust with the lengthy war came to a head with the Cambodian invasion of 1970 . While the door was wide open for negotiations when Nixon entered the White House in 1968 , this was not the route to be taken. The so-called Nixon Doctrine meant not a reevaluation of commitments but merely a contraction of the American force on hand to meet those commitments, with the gap to be filled by local forces. Far from cutting the defense budget, the Nixon administration provided for its steady increase, even after arms-limitation agreements had been concluded with the Soviet Union. Actions by the CIA under the new administration astounded many supporters of the presidential prerogative theory of war powers.

Given these circumstances, Congress had to seek means of restraining presidential war making. Congress sought the formal channel open to it; the legislative process. In 1972 and again in 1973 the Senate, with the support of most of its liberals and many of its conservatives, overwhelmingly passed a war powers bill conceived and promoted by Senator Jacob Javits of New York. This was but the beginning of the fight. Finally, on November 7, 1973, a War Powers Resolution was passed over the veto of the President. It provided that "the constitutional powers of the President as Commander in Chief to introduce United States Armed Forces into hostilities, or into situations where imminent involvement in hostilities is clearly indicated by the circumstances, are exercised only pursuant to (1) a declaration of war, (2) specific statutory

163. The First War Powers Act which surfaced during the period of LendLease consideration provided that Congress could repeal any act through concurrent resolution that sought to give the President too much power in war at the expense of the legislative body. This proviso was included in such legislation as the Lend-Lease Act, the Emergency Price Control Act, the Stabilization Act, and the War Labor Disputes Act to name a few. 
authorization, or (3) a national emergency created by attack upon the United States, its territories, or its armed forces." 164

The resolution contained consultation provisions, requiring the President to consult in every possible instance with the Congress both before introducing troops into such situations and regularly afterwards until the troops had been removed. It required the President to report within forty-eight hours to the Speaker of the House of Representatives and the President pro tem of the Senate after the introduction of troops in three circumstances: first, into hostilities or into situations where imminent involvement in hostilities is clearly indicated by the circumstances; second, into the territory, airspace, or waters of a foreign nation while equipped for combat, except for deployments which relate solely to supply, replacement, repair, or training of such forces; or, third, in numbers which substantially enlarge the United States armed forces equipped for combat already located in a foreign nation. 165 This report had to set forth the circumstances necessitating the introduction of these troops, the constitutional and legislative authority under which such moves took place, and finally, the estimated scope and duration of the hostilities or involvement. The resolution also required the President to provide other information as the Congress might request and to report to the legislative body periodically, at least every six months, so long as the troops continued to be engaged in the situation.

The real heart of the resolution was to be found in section five, which provided for termination of the use of U.S. troops abroad both by congressional inaction and by congressional action. Section 5 (b) called for any use of troops reported under section 4 (a) to be terminated automatically within sixty calendar

164. Public Law 93-148, "War Powers Resolution," concerning the war powers of Congress and the President. Passed November 7, 1973. Full text of resolution may be found in Appendix 非II.

165. Ibid., Appendix \#III. 
days unless Congress had declared war, enacted a specific authorization for such use, extended the sixty-day period, or was physically unable to meet because of an attack upon the United States. The resolution authorized extension of the sixty-day period by thirty days upon written presidential certification to Congress that the extension was necessary for the safe removal of the troops from the contested area.

Section 5 (c) called for the removal by the President of U.S. armed forces from any hostilities abroad in the absence of a declaration of war or specific statutory authorization if the Congress so directs by concurrent resolution.

Sections eight and nine add fuel to the fire. Section 8 (a) states that authority to introduce armed forces into hostilities or situations of imminent hostilities should not be inferred from any provision of law unless it specifically authorized the introduction of armed forces into such situations and stated that it was intended to constitute such authorization within the meaning of the resolution. The resolution also restricted the use of treaties as a justification for war making by the President by adding that authority to introduce troops was not to be inferred from any treaty unless it was implemented by legislation, meeting the criteria set forth in the resolution. This clause was not retroactive, however.

The resolution did not seek to change the constitutional separation of powers and so stated this in section 8 (d). In this section the case was made that nothing in the resolution was intended to alter the constitutional authority of the Congress or the President or the provisions of existing treaties, or to be interpreted as granting any body more power than it had from the original interpretation of the Constitution. 
Compliance with this resolution is still open to conjecture. Less than a month after PL 93-148 became law, a legal opinion was requested by Senator Thomas Eagleton from the State Department. The Department of State's interpretation did not offer much hope for strict adherence. ${ }^{166}$

By mid-1974 Senator Eagleton, who had become the frontrunner in criticism of administration war powers, claimed that action regarding the evacuation of Americans from Cyprus during hostilities between Turkish and Greek Cypriots might be a violation of the resolution. Ships and helicopters had been used to evacuate several hundred U.S. citizens in response to a request from the American Ambassador in Nicosia through the Department of State. Upon the approval of the Secretary of Defense, the Chairman of the Joint Chiefs of Staff had ordered a Task Force to proceed with the evacuation which began on July 22. The White House declared that the mission was clearly a humanitarian effort and that the evacuation was carried out by unarmed troops. ${ }^{167}$ Eagleton responded that "we must take the subjectivity out of the war powers reporting requirement and insist on automatic responses from the executive branch whenever our forces enter a country where there are ongoing hostilities or where

166. Letter of November 30, 1973, to Thomas F. Eagleton from Marshall Wright, Assistant Secretary of State for Congressional Relations, stated that "it is the Department's opinion that Section 2(c) does not constitute a legally binding definition of the President's Constitutional power as Commander-in-Chief. It is our opinion that this subsection is at most a declaratory statement of policy. There are, of course, fundamental questions whether such legislation could, even if so intended, limit the Constitutional authority of the President. Certainly the precedent of past practice supports a wider scope of Presidential authority than that contained in Section 2(c)." Committee Print, Subcommittee on International Security and Scientific Affairs of the Committee on International Relations, entitled: "Background Information on the Use of U.S. Armed Forces in Foreign Countries 1975 Revision", 94th Congress, 1st session, p. 38.

167. Washington Post, (August 2, 1974.) "U.S. Defends Evacuation on Cyprus", p. 2, col. 2. 
there is an imminent threat of such hostilities." 168 This is, in fact, what the law says.

While the Cyprus question served as a very early warning to backers of the War Powers Resolution, the real question as to executive compliance occurred where all the other problems between the Congress and the executive occurred, Southeast Asia. In April and May of 1975, in rapid succession, four incidents arose which required the executive to comply with the War Powers Resolution. Three of these situations dealt with the evacuation of American citizens, Vietnamese and Cambodian refugees, and third country nationals from both South Vietnam and Cambodia as the communist forces moved in for the kill in both countries. These three evacuations were justified by President Ford in this way: first, by the power invested in him as commander in chief under the Constitution; second, as a result of his executive power given him by the Constitution; and third, Ford contended that the Foreign Assistance Act of 1961 169

gave him the authority for such action.

These three actions offer a view that the President may be above the law as it is written. Congress was not consulted about these moves and was only informed after the evacuation had started. For instance, evacuation from Danang and other seaports in South Vietnam, with assistance of U.S. naval vessels, 12 helicopters and 700 Marines, began on April 3, 1975, yet a letter to Speaker of the House Carl Albert was not sent until April 4. Section 3 of the War Powers Resolution states, however, that "the President in every possible instance shall consult with Congress BEFORE introducing United States troops."

168. Congressional Record, (daily edition, August 2, 1974), S14181.

169. Foreign Assistance Act of 1961, as amended, authorized humanitarian assistance to refugees, civilian war casualties, and other persons disadvantaged by hostilities in South Vietnam. 
This provision was not followed and yet there must have been a contingency plan already formulated long before it was enacted. Why was Congress left out of this planning? These three actions did not require a loss of life; however, large amounts of the taxpayers' money was expended. The action of May 1975 was much different and included actual fighting by American armed forces.

On May 15, 1975, the President reported that he had ordered military forces to retake the SS Mayaguez, a U.S. merchant ship seized by Cambodian naval patrol boats in international waters, pursuant to his constitutional executive power and his authority as commander in chief of the United States armed forces. By his invocation of these powers, Mr. Ford signaled that he did not consider his power to make war as being limited by the resolution. His council, Roderick Hills, explained that the President acted under his constitutional war powers to protect lives and property of Americans. The U.S. was not, of course, at war with Cambodia, so that resort to the "war powers" was farfetched. What powers were given to the executive in the Constitution were very limited.

The sinking of Cambodian patrol boats and the invasion of the territorial soveriegnty of Cambodia is the main question here. Suppose this action had included vessels and territory of the Soviet Union instead of a pygmy nation like Cambodia. Such situations call for the collective judgment of the Congress and the President, as both the Constitution and the War Power Resolution expound. A few select members of Congress were consulted after the fact however, this cannot establish the constitutionality of some of the actions during the Mayaguez crisis.

The Mayaguez venture offers many probing questions to the student of American foreign policy, as well as to those interested in how this nation enters war. There were psychological advantages to be had. A frustrated President 
acting forcefully to stablize his sagging domestic constituency and the country's international credibility. The Congress, press, and public, all with visibly mixed feelings about Vietcong flags flying in capital cities of Southeast Asia, were glad to share in this therapy.

At first glance, the whole incident was a success. The ship and the entire crew was rescued; however, days after the mission, as the facts of it became public, interesting answers surfaced to questions which implied that the United States may not have learned much of a lesson from the long and enduring Vietnam War. America seemed more at ease with force than with diplomacy. Without diplomatic relations between the U.S. and Cambodia, contact between the two was channeled through the Cambodian embassy in Peking. White House sources stated that the Cambodians returned a diplomatic message sent by this country without reply two days after the operation. These same sources admitted they had no idea whether the Cambodians ever received the notes requesting release of the ship and crew. Two days after the message was sent Ford ordered forces into the situation. An interesting point arose here. Only two hours after the mission was begun the Phnompenh government ordered the Mayaguez out of Cambodian waters. Roger Morris contends that the United States did not give the Cambodians time to act. Says Morris, of the Cambodian order, it was "lengthy and propaganda-laden, the statement was obviously in the writing prior to the U.S. attack." 170 Morris, after reviewing this statement by Cambodia, feels that the Cambodians had released the crew not under presssure from the fighting, but rather as a diplomatic decision.

170. Roger Morris, "What to Make of Mayaguez," The New Republic: A Journal of Politics and the Arts, Vol. 172, No. 24 (June 14, 1975), p. 9. 
This action opens other doors for presidential criticism. Results of the operation throw new light on the presidential claim that only he has the expertise and dispatch to initiate war. The diplomatic intelligence regarding Cambodian intention was very poor if Mr. Morris' assumptions are correct. Also, the military planning was hastily put into operation and turned out as questionable as the diplomatic planning. The Marine company landing on Tang Island had little if any intelligence about Cambodian military strength. Whether there was not proper time to formulate effective plans or whether the intelligence gathering operations would have alerted the Cambodians of the coming action is not the question. What is important is that while the President claimed only he and his staff understood the problems of war, they were not very well qualified to do so in this situation.

Also there seem to have been some serious communication problems included in the action. For instance, after the crew had been retrieved and were safe on board an American naval vessel, the action continued. Between the Pentagon's receipt of the news that the crewmen were returned and the relay of that crucial message to the President, who immediately ordered the strikes to cease, there was a lapse of twenty-one minutes. It was during those twenty-one minutes that the carrier planes bombed the Cambodian mainland at an airfield near Sihanoukville.

In the official version the mainland raid was to protect the marines still on Tang Island, though the logic of those tactics would have dictated either a preventative strike timed with the initial landings more than three hours earlier, or simple surveillance of the field to attack any Cambodian planes attempting to take off. This bombing was obviously a punitive gesture. If the momentum of 
the operation was too strong to halt immediately why were planes and ships involved in the Cuban blockage in 1962 able to stop so quickly? Could the President have justified the sinking of a Russian vessel just because of military momentum? This would have almost assuredly provided the Soviets with reason to launch missiles toward our country. Another interesting point is that the administration considered sending B-52's into Cambodia during this crisis. Crisis diplomacy, indeed; this was an outright violation of the Constitution.

While the White House sought this bold action to revive sagging American prestige around the world, in reality the Mayaguez adventure showed that in the hands of the executive, U.S. crisis diplomacy is as uncoordinated and hypercritical as our military planning. Our military intelligence is as unreliable as our civilian communication with military leaders.

The House of Representatives met to determine Mr. Ford's compliance with the War Powers Resolution in connection with the seizing of the Mayaguez. Their findings were that the President complied only with the law as it is covered under section 4 , the reporting provision. ${ }^{171}$ In a statement by Senator Jacob Javits on this question, Senator Javits concluded that "The consultation of the Congress prior to the Mayaguez incident resembled to me the old and discredited practice of informing selected Members of the Congress a few hours in advance of the implementation of the decision already taken within the executive branch." 172 It appears that the consultation with Congress which the Ford administration boasted of including in this decision was in actuality a process of informing, not consulting.

171. Introductory statement by Clement J. Zablocki, Chairman, Subcommittee on International Security and Scientific Affairs of the Committee on International Relations of the House. Hearings entitled "War Powers: A Test of Compliance," 94th Cong., 1st Sess., p. $V$ (May 7 and June 4, 1975). 
What the Mayaguez action does lay bare, more than violation of the law by the President; is the great paradox, mentioned much earlier, regarding the relationship between the Congress and the executive. Once the enormous turmoil of the Vietnam War had subsided, Congress was less interested in presidential usurpation of the war powers. The congressional majorities which produced the War Powers Resolution were not anti-military, or even antiimperial; possibly they were not even concerned with the extension of presidential power at their expense. They were totally interested in the embroilment in Indo-china; once that disappeared, attitudes changed. The rallying point was dead and gone. What Mayaguez did do, with the approval of the Congress, was give the executive branch additional ammunition to use in future confrontations with the legislative branch. The inactivity by Congress at the height of the situation and its subsequent quick approval of the action thereby gives its sanction to yet another dismal "precedent" that future Presidents will not be slow to invoke involving the question of war and peace.

The unwarranted Iranian seizure of the American embassy in Tehran on November 4, 1979 gave the Carter administration the opportunity to confront the war powers situation. The illegality of the hostage taking and the subsequent demands made by the militant followers of the Ayatollah Khomeini were obviously violations of international law. Regardless, the 52 hostages were held for 442 days before being freed on the last day of Jimmy Carter's term in the White House. The event of the hostage taking and the time held is not the question here. Thought of war powers developed only after the ill-fated rescue mission of April 24, 1980 that the Carter administration had initiated. It was called off shortly after it had begun. 
The administration asserted that the President had not been obligated to consult with Congress under the War Powers Resolution since the action in Iran was a humanitarian rescue operation outside the scope of the Resolution.

The Senate Foreign Relations Committee did not accept this assertion and demanded a White House explanation. The committee hearings that followed dealt with guidelines for the future rather than examining the past. Especially, the committee sought presidential views on two points. First, consultation, as required in the War Powers Resolution, means more than merely informing Congress that an activity is underway or planned; consultation requires giving Congress an opportunity to participate in the decision making process. Second, the judgment concerning the need for and process of consultation in a particular situation cannot be made unilaterally by the President, but must be made by the President and Congress.

The administration's view of the situation and events were ably put forth by Acting Secretary of State Warren Christopher. In Mr. Christopher's opening statement, he sought to clear the air and reassure members of the committee by stating "We (the administration) do not challenge the validity of the War Powers Resolution, which expressly provides that it does not affect the constitutional powers of the President." 173

Throughout this secret hearing the Carter administration maintained the presidential right to undertake the rescue mission and few, if any, would argue that success would have meant a great deal. Mr. Christopher concluded that only the extraordinary circumstances allowed such a decision, outside of Congress, to be made. In closing, the Acting Secretary stated that "I want to

173. Hearing before the Committee of Foreign Relations United States Senate, 96th Congress, 2nd Session, (May 8, 1980), p. 9. 
emphasize that the administration does not regard the extraordinary circumstancs of this case as a precedent for avoiding consultation with the Congress; nor do we contend that the President is free to avoid consultation in any case where he desires secrecy." 174

The importance of the situation in Iran is not the issue of the hostage taking itself but rather certain views which came out of those 1980 hearings. First, while denying it, there appeared to be a feeling that the President and the President alone has the discretionary power to consult with Congress. Second, consultation may mean "with the leadership of the House and Senate," whatever that implies. Third, as Senator Church implied, a President would not seek consultation with a group which might disagree with his decision. ${ }^{175}$

This event which finally ended with the negotiated settlement and release of the hostages on January 20, 1981 can be used again and again in the future. While Mr. Carter could see nothing in the action which set precedence, only time will afford it such. How future Presidents employ this situation will determine its precedential value.

The War Powers Resolution, as it stands today, is not a cure-all. The situations just described show that there are enough loop holes to allow most executives as much breadth in the handling of war powers as they had before PL 93-148. Resolutions such as this, which stress procedure for policy formulization must be very clear. Rather than limit presidential use of force; Congress, through resolutions, may have even inadvertently given the President more power. For instance, speaking of the conference committees report on the War Powers Resolution, Senator Goldwater stated that the resolution coming from this report would strengthen the executive. When questioned by Senator

174. Ibid., p. 6.

175. Ibid., p. 38. 
Eagleton, the Arizona Republican commented that "it appears to me that the President is no longer prohibited from initiating original actions. He needs only to report during the first 60 days." 176

If Congress is to have a role in formulizing war policy, then proper procedure must be established for the reporting and consultation between the branches of government. There have been numerous proposals for establishing consultation with Congress before forces are deployed. The best proposal seems to be that of Alfred DeGrazia. In hearings before the Subcommittee on Separation of Powers of the Committee on the Judiciary in the United States Senate, DeGrazia suggested that at each session of Congress a committee might be established to join with the President in deciding when forces were necessary. 177 This group, which DeGrazia called the "Force Committee", would have the authority to participate in the making of the decision and explicit approval over the introduction of American forces.

Professor Henry Commager struck at the executive claim that Congress is not always in session when crisis might arise by suggesting a full-time body within Congress for consultation purposes. Offered Commager, "that the Senate meet the argument of emergency, hypothetical as it is, by creating a permanent committee, a quorum of whose members would remain permanently in Washington, with authority to require that the President consult with the Senate or the Congress before taking any action that might involve the Nation in armed conflict. Such a committee could be counted on to respond to a genuine

176. Eagleton, War and Presidential Power, p. 207.

177. Hearings before the Subcommittee on Separation of Powers of the Committee on the Judiciary of the United States Senate, "Separation of Powers," 90th Congres, 1st Sesseion, statement by Professor Alfred DeGrazia, p. 164. 
emergency just as promptly as would the President, and counted on too, to present the case for caution." 178

Certainly, the interpretations of resolutions are important, as well as proper channels of consultation; however, in order to reestablish any control of the war powers to its rightful spot, the Congress, much change in the thinking of the institutions involved will be needed. Congress can be very effective if it is included in the early stages of foreign policy-making, when options are still open and positions have yet to harden. For instance, at the time of the Tonkin crisis in 1964, Congress could do little else but follow along in the footsteps of the administration. The time for influence by Congress was during the prior decade, when U.S. involvement in Vietnam was beginning to take shape and Congress was appropriating funds to make that involvement possible.

Change will not be an easy process to start in motion. Congress just will not be able to say, "here we are." The White House has taken these powers, it is the role of the White House to return them to their proper owners. Congress will surely have to force the hands of the executive branch through the legislative process at its disposal. A brief review of the so-called Cooper-Church amendment may offer an example of this type of action.

The action by Senators John Sherman Cooper and Frank Church followed attempts by Senator Cooper in 1969 which sought to restrict presidential authority pursuant to action in Southeast Asia. Cooper sponsored an amendment to the defense appropriations bill of 1969 which specified that no funds were to be used by the executive to introduce ground toops into Laos and Thailand. This was a direct move by Congress to keep the United States from spreading the

178. Hearings before the Senate Committee on Foreign Relations on Senate Bill 731, and Senate Joint Resolution 18, 92nd Congress, 1st Session, March 8, 1971 , p. 17. 
existing war into those two nations. What Congress did not foresee was the movement by Nixon into Cambodia in the Spring of 1970. The Cooper-Church amendment was put into motion after that May 1970 invasion. Specifically, the amendment aimed at barring the retention of U.S. troops in Cambodia after July 1, 1970. This bold congressional act also recognized for the first time, in legislative terms, the close relationship between tactical maneuvers in the field and larger policy questions affecting the whole of American policy in Southeast Asia.

When the next year's appropriations legislation came before Congress it included a stipulation that none of the funds authorized or appropriated pursuant to that act, or any other, could be used to finance the introduction of United States advisers to or for operations in Cambodia. This legislation, entitled the Special Foreign Assistance Act of 1971, had its short coming, however. It specified that the restrictions pertained to ground troops, which was its downfall. In its bombing operations in Cambodia, and in its subsequent incursions into Laos, the administration interpreted air power in such broad terms as to circumvent some of the earlier legislative restrictions. The White House interpreted planes and helicopter gunships flying at tree top level as not constituting a violation of statute. Thus, it can be seen that legislative restriction on presidential war making activities must not leave a stone unturned.

The Congress has since sought to improve its position vis-a-vis the President in the funding field. Besides actions like the Cooper-Church amendment, Congress has moved formally to reestablish its participation in this process. The Congressional and Impoundment Control Act of 1974 (Public Law 94-344) has created a Congressional Budget Office and has thus strengthened congressional control over the national budget. This statute appears to be a 
direct result of the presidential impoundment practice which became so overworked in the 60's and early 70's. Another impetus for this change lies in fights between the authorizing and fiscal committee. As champions of their programs, the authorizing committee would accuse the appropriating committee of ignoring expert judgment and providing meager funding. This Act set up procedures to curb this internal pressure in Congress and to review presidential impoundments.

Another area that requires additional clarification through the legislative channels available is that of initiating hostilities in the absence of a declaration of war. Is there to be a time when the executive might engage U.S. troops without this declaration and not in times of repelling a direct attack on the United States? If there is to be such a time, there must be very clear guidelines. This might be called the "neutrality theory" of congressional participation in the war powers question. Only the protection of American lives and property during civil disorder appears to remain as a possible candidate for such neutrality and even here the deployment of the armed forces will generally be highly suspect. Intervention at the request of a local government to suppress a revolutionary guerrilla band usually is tantamount to taking sides in a political contest which, as Vietnam illustrates, may grow to unforeseeable dimensions when the rebels have external support or sympathizers. Consequently, every decision to commit troops to combat becomes a potential subject for congressional deliberation. At the same time, however, it must be recognized that there will be cases where, in the executive's judgment, there simply is no time to secure congressional authorization before acting. In such cases, where he believes that Congress would agree with his judgment that the interest at stake is worth defending at the risk of war, the President should be able to take action while simultaneously seeking the authorization of Congress. This was the particular reasoning behind 
the "National Commitments" hearings of 1967. 179 These cases should be few. None of the recent military actions appear to have involved such genuine urgency as to preclude congressional participation in the decision to employ the military.

The difficulty of drawing a line between what is permissible for the executive and what is absolutely congressional in nature cannot be avoided. A major consideration to keep in mind as this difficulty is faced is that the overall presumption should be that congressional collaboration is the general rule wherever the use of military force is involved, rather than that the President may deploy troops as he sees fit and seek congressional approval only in the exceptional case. It is for Congress to determine whether this nation shall remain neutral in a particular situation which could require the introduction of combat troops of this country's armed forces, not the executive.

179. These hearings, which culminated with a committee print explaining the American commitments to that date, would be very helpful to a President when trying to judge congressional reaction in advance. The resolution which came about as a result of these hearings starts out in this way:

Whereas the executive and legislative branches of the United States Government have joint responsibility and authority to formulate the foreign policy of the United States; and

Whereas the authority to initiate war is vested in Congress by the Constitutuion:

Now, therefore, be it

Resolved, That a commitment for purposes of this resolutin means the use or promise to a foreign state or people to use, the armed forces of the United States either immediately or upon the happening of certain events, and

That it is the sense of the Senate that, under any circumstances which may arise in the future pertaining to situations in which the United States is not already involved, the commitment of the armed forces of the United States to hostilities on foreign territory for any purpose other than to repel an attack on the United States or to protect United States citizens or property properly will result from a decision made in accordance with constitutional processes, which, in addition to appropriate executive action, require affirmative action by Congress specifically intended to give rise to such commitment.

From Senate Report $¥ 797,90$ th Congress, 1st Session, Senate Foreign Relations Committee, "National Commitment", p.1. 
There are also formal means of change that could conceivably alter the balance of power between the two competing branches of government. Robert A. Dahl has stated that much of the legislative decline in influencing foreign policy "must be attributed to the profound change in the requirements of public policy-making and to the failure of Congress to alter its organization to cope with the new demands made upon it." 180

To make the Congress most effective there must be more structural and procedural reforms. For instance, it is clear that the crowded schedules of Senators and Representatives do not permit effective oversight of administration policies. Steps are being taken to ease this pressure and to streamline procedures. Legislation like the Legislative Reorganization Act of 1970 sought to reaffirm the oversight powers of Congress by specifying that each standing committee of Congress should review and study, on a continuing basis, the application, administration and execution of those laws, the subject matter of which is within the jurisdiction of that committee. Electronic voting systems have also helped. One result of this has been the increased use of record votes, thus making legislators more responsible and accountable to their constituents.

Another mechanical innovation is the Senate amplification system. While one might at first glance, say this was but a move to add glamour to the chambers, it should be noted that during the debate of the 1964 Tonkin Gulf Resolution many Senators complained that they could not hear their colleagues. One Senator who was somewhat skeptical of the resolution claimed he could not

180. Robert A. Dahl, Congress and Foreign Policy (New York: W.W. Norton \& Company, 1950), p. 85. 
hear some important debate which might have influenced his vote on the issue. $^{181}$

Larger, more expert staffs are also needed. How can Congress compete with the massive staffs that exist in the executive branch with so feeble a staff? Staff membership is pathetically small by comparison to the executive branch. If one were to couple more staff personnel with smaller committees, Congress might be better able to conduct its own background studies and check the accuracy and consistency of executive statements and provided information. Extensive use of such agencies as the General Accounting Office and the Congressional Research Service would help committees evaluate legislative proposals in order to determine the merits of bills, to estimate their probable results, and to evaluate alternative means of accomplishing the same results. All these new views would be from the congressional perspective rather than the perspective of the executive branch only. Another possible move by the Congress which would surely provide aid to the legislators would be the establishment of a congressional intelligence agency. While this could not be nearly as sophisticated as the agencies which the executive branch relies on, it might provide some information otherwise unavailable to the Congress. This agency should not, however, have any type of covert function. This nation does not need another group charged with any special operations function.

181. Senator Gaylord Nelson complained that he could not hear the discussion between Senator Fulbright and two other Senators, while Fulbright admitted at one point that a diversion had prevented him from hearing what Nelson had said. Other Senators must have experienced difficulty in hearing the debate, but considered it indelicate to advertise the fact in the public record. The resolution was very popular throughout the nation in the summer of 1964 and these Senators did not want to rock the boat because of some technical problem in the Senate chambers.

Fisher, Louis, President and Congress, p. 232. (New York:Free Press 1972). 
These changes alone, however, will not overcome the problem of the unrepresentative structure of committees; military types dominate the committees and subcommittees that authorize and appropriate funds for the Defense Department. Part of that ideological bias is in fact caused by liberals when they concentrate their interests on such committees as Senate Foreign Relations, Senate Labor and Public Welfare, and House Education and Labor. Surely a seat on Armed Services is important for urban constituencies in terms of establishing a balance between military and domestic spending.

If these changes do not have a positive impact on the congressional committee structure, then structural change can provide only limited improvements regarding that body's role in its relations vis-a-vis the executive. The greater hope, perhaps, lies in increasing sensitivity to the problem of joint possession of constitutional powers. Greater awareness of this problem, to which many for so long were oblivious, may lead to a more serious consideration of the problem. Concern for this by both the executive and the Congress may restrain executives and restrain congressional action from going beyond what is necessary.

At a time when the sense of a need for improvement is strong, and resistance to change is weakened by memories of Vietnam, Watergate and Iran, it might be desirable for Congress and the President to enter negotiations with a view to reestablishing general relations on a cooperative, less distrustful, less adversary basis; not to do away with the concept of separation of powers but to make it work better.

There are any number of areas which could provide a starting place for a new relationship between the two branches of government. Reevaluation of the secrecy problem between Congress and the executive might be a good place to start. While some secrecy may be needed, there is surely more than is necessary 
being used by the executive branch. Possibly an overhauling of the classification system is in order. Much material concerning the Vietnam War is now open to the public; however, this only became available after the controversial printing of The Pentagon Papers in 1971 . Leakage is not the proper method for providing classified information to Congress. Frequent review of classified items is necessary and this review should be by a body which includes congressional and public representation, as well as members of the executive office.

The role executive agreements may have in the use of American forces abroad is another source of great uneasiness by Congress. Here the legislative body has acted. The Case Act, (Public Law 92-403), passed in August of 1972, requires that executive agreements be reported to the Congress for its information or, if classified, to the two foreign affairs committees of Congress within sixty days. While this law inevitably influences presidential action, the mission for the Senate as a whole seems to have disappeared with this move. ${ }^{182}$ Also, if the agreement is to be kept secret, who is to say that the executive must present the proposal to even the committees foreign affairs of the Congress? Pessimism here is built upon the fact that the only way for this law to carry any weight is for Congress and the President to conclude a gentlemen agreement, something that previous executives have failed to uphold.

182. The Constitution gives the entire Senate a role in treaty consideration. If the executive agreement is to be the main facility for interaction between the United States and other nations the role of the Senate will be greatly limited. The trend toward extensive use of the executive agreement has reached such proportions that by May 1972 the Nixon administration had concluded 608 agreements while only 71 treaties. Schlesinger, The Imperial Presidency, p. 313. (During the first half century of the nation's life, 60 treaties and 27 executive agreements were signed. As of January 1, 1981, there were 967 treaties and 6,188 executive agreements in force). 
One vehicle that Congress may use to influence presidential actions is the legislative veto. This need not be considered a totally negative factor. The legislative veto can be used effectively for oversight of policy, that is, in the legislative process, in those cases where the more usual techniques of oversight fail to provide adequate legislative control. This will be the case where Congress most frequently is unable to define standards clearly in the authorization legislation.

The legislative veto cannot be used effectively, however, for oversight of White House performance; that is, in the administrative process. The problem here is that in order to be implemented, the veto has to be tied on to something. When the veto is directed to policy, it is relatively easy to attach it to some broad policy provision. When the veto is directed to administration operations, however, the only hitching points are isolated details, and it is hard to find specific actions through which an administration's general efficiency can be checked.

One final proposal which might help dispel the distrust between the two branches of government would be better liaison during times of foreign policy consideration and crisis diplomacy. The executive branch has officials for congressional relations; is there a way of duplicating the process so that Congress can send into the executive office its information gathering personnel? Perhaps a small, select group, members of Congress or their staff, should have access to the cablegrams, attend executive meetings, participate in discussions, etc. Or, as suggested by Professors DeGrazia and Commager, ${ }^{183}$ there might be a special executive-legislative council on foreign affairs meeting regularly.

183. Hearing before the Committee on International Relations of the House, entitled, "War Powers"A Test of Compliance," 94th Cong., 1st Sess., p. 62. (May 7 and June 4, 1975). 
These innovations might start the process toward balancing the constitutional powers of the executive and Congress however, optimism is not called for. Any novel arrangements, whether in a specific area like war powers, or in regard to foreign affairs generally, would be very difficult to achieve. If a battered executive branch might be persuaded to experiment, continued effort would still be needed to keep any new arrangements alive. It could not be a oneway street either. Congress would have to repose full faith and credit in the few individuals, legislators or staff, selected for the role; to respect scrupulously classified information and executive confidentiality; and to protect carefully the special machinery and process from partisan political abuse. This does not imply any congressional prerogative.

In the future, then, Congress is entitled to honest and timely information. Whether Congress will accept the responsibility of decision making and maintain continuing, meaningful participation and control is another question. The Congress has not always seen fit to do this. In 1971 Professor Alexander Bickel said, before the Senate Foreign Relations Committee then considering the CaseZablocki bill that, "Congress has too long tolerated, indeed cooperated in, a diminution of its role in the conduct of foreign affairs and in the questions of war and peace - a diminution that approaches the vanishing point. In my judgment, the balance of power between Congress and the President ought to be redressed in this respect. It is up to Congress to do the redressing ..." ${ }^{184}$ If the executive branch of government should offer Congress the means by which it can become an equal partner in the policies of war and peace the general feeling is that Congress may not be ready to accept it. One should be less than

184. Hearings before the Committee on Foreign Relations, United States Senate, 92nd Congress, 1st Session, on Senate Bill 596, entitled "Transmittal of Executive Agreements to Congress," p. 54. 
optimistic that the executive will provide such a means without extremely harsh pressure applied by not only the Congress but also the courts.

Legislative reassertion is not in itself, of course, a foolproof antidote for future Vietnams and large defense budgets. Congress' past record of partnership with the military is plain enough and is, in fact, continuing. But neither is there hope in legislative acquiescence to executive expertise, especially when the latter becomes synonymous with incompetence and deceit. That is why Congress has to begin, as it has, to build independent expertise to monitor and question foreign policy commitments, which all too often have been the personal undertakings of the President, abetted by the bureaucracy, rather than a commitment by the government and the nation as a whole.

To complement this new congressional competence there must be, as mentioned above, a new temperament and attitude among legislators: a courage to resist being stampeded into granting power simply because the President waves the flag; a resolve to defer to no one in the exercise of independent judgment; a determination to treat reassertion not as a temporary phenomenon needed to restore constitutional balance but as a permanent, nonnegotiable legislative responsibility. Congress has demonstrated rather impressively that it can change its attitudes and its procedures and contribute intelligently to foreign policy making. The larger question is whether it has the will and the staying power to contribute from one year to the next, in times of relative calm as well as during crisis, without reverting to its habitual acquiescence to the President.

The suggestions offered as remedies are highly tentative. This writer is confident only of the needs to which they are addressed: to establish new attitudes and forms of cooperation running in both directions between Congress and the President, to inform Congress effectively of American foreign policies which might lead to open war with other nations, and to allow Congress to 
participate in the process of formulating and implementing the foreign policy that can have such a staggering effect on American life.

Separation of powers is not supposed to be an adversary game. Our effectiveness in dealing with the problems of the 1980's and beyond will depend to a significant degree on our ability to resolve the adversary relationship between the President and Congress. Granted, the United States cannot afford a policy of initiating hostility which is hostage to the emotions of the moment. However, to close the door of cooperation by stating that "Congress has inhibited the President's freedom of action and denied him the tools necessary for the formulation and implementation of American foreign policy," ${ }^{185}$ is absurd. This separation does not imply or require that the two sources meet at arms length, but rather they are to work together to enable each to exercise its independent judgments. It does not require that each branch in this game conceal information from the other, but rather it hopes for cooperation which will allow a flow of information between both branches so they can operate as the Constitution saw fit. The suggestions proposed seek to do just this.

185. Foreign Affairs Vol. 60, No. 2 Winter 1981/82, p. 246, Congress versus the President:The Formulation and Implementation of American Foreign Policy by Senator John G. Tower of Texas, 


\section{A SELECTED BIBLIOGR APHY}

Books

Acheson, Dean. A Citizen Looks at Congress. New York: Harcourt, Brace and World, 1967.

Ames, Herman V. Annual Report of the American Historical Association, 1896.

Bauer, K. Jack. The Mexican War 1846-1848. New York: MacMillan Publishing Company, 1974.

Bickel, Alexander M. The Least Dangerous Branch: The Supreme Court at the Bar of Politics. Indianapolis: Bobbs-Merrill Press, 1962.

Bobrow, Davis B. Components of Defense Policy. New York: Rand McNally Press, 1971.

Corwin, Edwin S. The President: Office and Power 1787-1957. 4th ed. New York: New York University Press, 1957.

- Total War and the Constitution. New York; Alfred A. Knopf, 1947.

Dahl, Robert A. Congress and Foreign Policy. New York: W.W. Norton and Company, 1950 .

Eagleton, Thomas. War and Presidental Power: A Chronicle on Congressional Surrender. New York: Liveright Press, 1974.

Falk, Richard A. The Vietnam War and International Law. Vol. II. Princeton: Princeton University Press, 1969.

Farrand, Max. The Records of the Federal Convention. Revised ed. New Haven: Yale University Press, 1937.

Fisher, Louis. President and Congress: A Power and Policy. New York: Free Press, 1972.

Fulbright, J. William. The Arrogance of Power. New York: The Liberal Arts Press, 1954.

Gabriel, Ralph H. Hamilton, Madison and Jay on the Constitution: Selections from The Federalist Papers. New York: The Liberal Arts Press, 1954.

Gough, J.W. The Second Treatise of Government by John Locke. Oxford: Basil Blackwell and Mott, 1946.

Hutchinson, William T. and Rachel, William M.E., eds. The Papers of James Madison. Vol. 2, 20 March 1780-23 February 1781. Chicago: University of Chicago Press, 1974. 
Jensen, Merrill. The Articles of Confederation: An Interpretation of the SocialConstitutional History of the American Revolution 1774-1781. Madison: University of Wisconsin Press, 1940.

Johnson, Lyndon B. The Vantage Point: Perspectives of the Presidency 19631969. New York: Holt, Rinehart and Winston, 1972.

Leopold, Richard W. The Growth of American Foreign Policy: A History. New York: Alfred A. Knopf, 1962.

Manchester, William. The Glory and the Dream: A Narrative History of American 1932-1972. Boston: Little, Brown and Company, 1973.

May, Ernest. The Ultimate Decision: The President as Commander in Chief. New York: G. Braziller Press, 1960.

McDonald, Archie P. The Mexican War: Crisis for American Democracy. Washington: D.C. Heath and Company, 1969.

Morison, Elting E. The Letters of Theodore Roosevelt: The Big Stick 1907-1909. Vol. 6. Cambridge: Harvard University Press, 1951-1956.

Nixon, Richard M. A New Road for America: Major Policy Statements. New York: Doubleday, 1972.

Rakove, Jack N. The Beginnings of National Politics: An Interpretive History of the Continental Congress. New York: Alfred A. Knopf, 1979.

Rossiter, Clinton. Parties and Politics in America. Ithaca: Cornell University Press, 1961.

- The American Presidency. New York: Harcourt, Brace and World, 1960.

Schlesinger, Arthur M. The Imperial Presidency. New York: Popular Library, 1974.

- A Thousand Days. Cambridge: Houghton-Mifflin Company, 1965.

Sutherland, George. Constitutional Power and World Affairs. Princeton: Princeton University Press, 1913.

Taft, William Howard. Our Chief Magistrate and His Power. New York: Columbia University Press, 1916.

Walton, Richard J. Cold War and Counterrevolution: The Foreign Policy of John F. Kennedy. New York: The Viking Press, 1972.

White, Theodore C. Kennedy. New York: Harper and Row, 1965.

Wilson, Woodrow. Constitutional Government in the United States. New York: Columbia University Press, 1908. 
Articles in Journals/Magazines

Berger, Raoul. "The Presidental Monopoly of Foreign Relation." Michigan Law Review, Vol. 71, no. 1 (November 1972), 1-58.

- "War-Making by the President." University of Pennsylvania Law Review, Vol. 121 (1972), 29-86.

Berry, John M. "Foreign Policy Making and the Congress." Editorial Research Report, Vol. 1, no. 15 (April 19, 1967), 283-300.

Commager, Henry Steele. "Can We Limit Presidential Power?" The New Republic, (April 6, 1968), 15-18.

Fulbright, J. William. "American Foreign Policy in the 20th Century Under an 18th Century Constitution." Cornell Law Quarterly, Vol. 47, no. 1 (Fall 1961), 1-3.

Goldberg, Arthur J. "A Constitutional Confrontation." American Association of University Women, (April 1973), 204.

Goldwater, Barry M. "The Presidents' Ability to Protect America's Freedom-The Warmaking Power." Arizona State University Law Journal, Vol. 1971, no. 3 (1971), 424.

Gould, James W. "The Origins of the Senate Committee on Foreign Relations." The Western Political Quarterly, Vol. 12, no. 3 (September 1959), 670-682.

Graham, Fred P. "Introduction--Toward a Jurisprudence of Peace?" Boston University Law Review, Vol. 50, Special Issue (1970), 1-5.

Henkin, Louis. "A More Effective System for Foreign Relations: The Constitutional Framework." Virginia Law Review, Vol. 61, (1975), 751776.

Hilsman Roger. "Congressional-Executive Relations and the Foreign Policy Consensus." The American Political Science Review, Vol. III, no. 3 (September 1958), 725-744.

Humphrey, Hubert H. "The Senate in Foreign Policy." Foreign Affairs, Vol. 37, no. 4 (July 1959), 525-536.

Javits, Jacob K. "The Congressional Presence in Foreign Relations." Foreign Affairs, Vol. 48, no. 2 (January 1970), 221-234.

Kauper, Paul G. "The Steel Seizure Case: Congress, the President and the Supreme Court." Michigan Law Review, Vol. 51, no. 2 (December 1952), 141-182.

Keown, Stuart S. "The President, the Congress, and the Power to Declare War." The University of Kansas Law Review, Vol. 16 (1967), 82-97. 
Lofgren, Charles A. "War-Making Under the Constitution: The Original Understanding." The Yale Law Journal, Vol. 81 (1972), 672-702.

Marks, Frederick W. "A Winning Issue in the Campaign for Ratification of the United State Constitution." Political Science Quarterly, Vol. 86, no. 3 (1971), 444.

Meeker, Leonard. "The Legality of United States Participation in the Defense of Vietnam." State Department Memorandum in The Yale Law Journal, Vol. 75 , no. 7 (June 1966), 1085-1108.

Monaghan, Henry P. "Presidential War-Making." Boston University Law Review, Vol. 50, Special Issue (1970), 19-33.

Morris, Roger. "What to Make of Mayaguez." The New Republic, Vol. 172, no., 24 (June 14, 1975), 9-12.

Notes. "Congress, the President, and the Power to Commit Forces to Combat." Harvard Law Review, Vol. 81, no. 8 (June 1968), 1771-1805.

Putney, Albert H. "Executive Assumption of the War Making Power." National University Law Review. Vol. VII, no. 2 (May 1927), 34.

Ratner, Leonard G. "The Coordinated Warmaking Power--Legislative, Executive, and Judicial Roles." Southern California Law Review, Vol. 44 (1971), 461-489.

Reed, Randal Penn. "Foreign Policy and the Initiation of War: The Congress and the President in the Dispute Over War Powers." The Potomac Review, Vol. 6, no. 1 (Winter 1973), 1-29.

Reveley, W. Taylor. "Presidential War-Making: Constitutional Prerogative or Usurpation?" Virginia Law Review, Vol. 55, no. 7 (November 1969), 12431305.

Roberts, Chalmer M. "The Day We Didn't Go to War." The Reporter, (September 1954), 41-48.

Rogers, William P. "Congress, the President and the War Powers." California Law Review, Vol. 59, no. 1 (January 1971), 1203-1241.

- "Constitutional Law: The Papers of the Executive Branch." American Bar Association Journal, Vol. 44, no. 9 (Septembver 1958), 940-981.

Rusk, Dean. "The President." Foreign Affairs, Vol. 38, no. 1 (April 1960), 4-12.

Schlesinger, Arthur M. "Congress and the Making of American Foreign Policy." Foreign Affairs, Vol. 51, no. 1 (October 1972), 78-113.

Spong, William B. "Can Balance Be Restored in the Constitutional War Powers of the President and Congress?" University of Richmond Law Review, Vol. 6, no. 1 (Fall 1971), 1-31.

The Editor. "Citing Mayaguez." The New Republic, Vol. 172, no. 26 (June 28, 1975), 32-33. 
Tower, John G. "Congress Versus the President: The Formulation and Implementation of American Foreign Policy." Foreign Affairs, Vol. 60, no. 2 (Winter 1981/82), 229-246.

Velvel, Lawrence R. "The War in Vietnam: Unconstitutional, Justiciable, and Jurisdictionally Attackable." Kansas Law Review, Vol. 16 (1968), 449504.

Wormuth, Francis D. "The Nixon Theory of the War Power: A Critique." California Law Review, Vol. 60, no. 3 (May 1972), 623-703.

Newspaper Article

The New York Times. April 18, 1952, 13.

The New York Times. November 8, 1942, 26.

The New York Times. Marvin Kalb, November 19, 1967, 72.

The New York Times Book Review. John Kenneth Galbraith, October 8, 1972, 12.

The Washington Post, August 2, 1974, 2.

Public Documents

U.S. Congress. House. Committee on International Relations. Background Information on the Use of U.S. Armed Forces in Foreign Countries, 1975 Revision. Hearing before a subcommittee of the Committee on International Relations, House of Representatives, 94th Cong., 1st Sess., 1975.

U.S. Congress. Senate. Committee on Foreign Relations. Congress and the Termination of the Vietnam War. Committee print prepared by Congressional Research Service. U.S. Senate, 93rd Cong., 1st Sess., 1973.

U.S. Congress. Senate. Committee on Foreign Relations. The Iran Agreements. Hearings before the Committee on Foreign Relations, U.S. Senate, 97th Cong., Ist Sess., 1981.

U.S. Congress. Senate. Committee of Foreign Relations. Membership and Jurisdiction of Subcommittees. Committee on Foreign Relations, U.S. Senate, 95th Cong., 1st Sess., 1977.

U.S. Congress. Senate. Committee on Foreign Relations. National Commitments. Report from the Committee, Committee on Foreign Relations, U.S. Senate, 90th Cong., 1st Sess., 1967. 
U.S. Congress. House. Committee on International Relations. Seizure of the Mayaguez. Hearings before the Committee on International Relations, House of Representatives, 94th Cong., 1st Sess., 1975.

U.S. Congress. Senate. Committee on the Judiciary. Separation of Powers. Hearings before the Committee on the Judiciary, U.S. Senate, 90th Cong., 1st Sess., 1967.

U.S. Congress. Senate. Committee on Foreign Relations. The Situation in Iran. Committee on Foreign Relations, U.S. Senate, 96th Cong., 2nd Sess., 1981.

U.S. Congress. Senate. Committee on Foreign Relations. Treaty Powers Resolution. Hearings before the Committee on Foreign Relations, U.S. Senate, 94 th Cong., 2nd Sess., 1976.

U.S. Congress. House. Committee on Foreign Affairs. War Powers. Hearings before the Committee on Foreign Affairs, House of Representatives, 93rd Cong., 1st Sess., 1973.

U.S. Congress. House. Committee on International Relations. War Powers: A Test of Compliance. Hearings before the Committee on International Relations, House of Representatives, 94th Cong., 1st Sess., 1975.

U.S. Congress. Senate. Committee on Foreign Relations. War Powers Legislation. Hearings before the Committee on Foreign Relations, U.S. Senate, 92nd Cong., 1st Sess., 1971.

U.S. Congress. House. Committee on Foreign Affairs. War Powers Legislation. Hearings before the Committee on Foreign Affairs, House of Representatives, 92nd Cong., 1st Sess., 1971.

U.S. Congress. House. Committee on International Relations. The War Powers Resolutions. Committee Print prepared by the Committee on International Relations, House of Representatives, 94th Cong., 2nd Sess., January 1976.

U.S. Constitution. Entire text.

U.S. President. Public Papers of the President 1963-1964. Washington, D.C.: Government Printing Office. Lyndon B. Johnson, 1965.

U.S. Congress. Senate. Senator Goldwater speaking before Congress. S. 5640, 91 st Cong., 1st Sess., April 26, 1971 . Congressional Record 117.

U.S. Congress. Senate. Senator Fulbright speaking before Congress. S. 18409, 88th Cong., 2nd Sess., August 5, 1964. Congressional Record 110.

U.S. Congress. Senate. Senator McGovern speaking before Congress. S. 9371, 93rd Cong., 1st Sess., May 17, 1973. Congressional Record 119. 


\section{APPENDIX I}

Instances of Use of United States Armed Forces Abroad, 1798-1977, inclusion of an event in this list does not connote either legality or illegality.

1798-1800-- Undeclared naval war with France. - This contest included land actions, such as that in the Dominican Republic, city of Puerto Plata, where marines captured a Franch privateer under the guns of the forts.

1800- West Indies - April 1. -- U.S. marines participated in the action between the U.S. schooner Enterprise and a Spanish man-of-war brig in the West Indies.

1801-1805-Tripoli -- the First Barbary War, including the George Washington and Philadelphia affairs and the Eaton expedition, during which a few marines landed with United States Agent William Eaton to raise a force against Tripoli in an effort to free the crew of the Philadelphia. Tripoli declared war but not the United States.

1806- Mexico (Spanish territory) -- Capt. Z.M. Pike, with a platoon of troops, invaded Spanish territory at the headwaters of the Rio Grante deliberately and on orders from Gen. James Wilkinson. He was made prisoner without resistance at a fort he constructed in present day Colorado, taken to Mexico, later released after seizure of his papers. There was a political purpose, still a mystery.

1806-1810- Gulf of Mexico -- American gunboats operated from New Orleans against Spanish and French privateers, such as La Fitte, off the Mississippi Delta, chiefly under Capt. John Shaw and Master Commandant David Porter. 
1810- West Florida (Spanish territory) -- Gov. Claiborne of Louisiana, on orders of the President, occupied with troops territory in dispute east of Mississippi as far as the Pearl River, later the eastern boundry of Louisiana. He was authorized to seize as far east as the Perdido River. No armed clash.

1812- Amelia Island and other parts of east Florida, then under Spain -Temporary possession was authorized by President Madison and by Congress, to prevent occupation by any other power; but possession was obtained by Gen. George Matthews in so irregular a manner that his measures were disavowed by the President.

*** 1812-1815-- Great Britain -- War of 1812. Formally declared.

1813- West Florida (Spanish territory) -- On authority given by Congress, Gen. Wilkinson seized Mobile Bay in April with 600 troops. A small Spanish garrison gave way. Thus U.S. advances into disputed territory to the Perdido River, as projected in 1810. No fighting.

1813-1814-- Marqueses Islands -- Built a fort on island of Nudahiva to protect three prize ships which had been captured from the British.

1814- Spanish Florida -- Gen. Andrew Jackson took Pensacola and drove out the British with whom the United States was at war.

1814-1825- Caribbean -- Engagements between pirates and American ships or squadrons took place repeatedly especially ashore and offshore about Cuba, Puerto Rico, Santo Domingo, and Yucatan. Three thousand pirate attacks on merchantmen were reported between 1815 and 1823. In 1822 Commodore James Biddle employed a squadron of two frigates, four sloops of war, two brigs, four schooners, and two gunboats in the West Indies.

1815- Algiers -- The Second Barbary War, declared by the opponents but not by 
the United States. Congress authorized an expedition. A large fleet under Decatur attacked Algiers and obtained indemnities.

1815- Tripoli - After securing an agreement from Algiers, Decatur demonstrated with his squadron at Tunis and Tripoli, where he secured indemnities for offenses during the War of 1812 .

1815- Second Barbary War (Algeria) -- In 1812 an Algierian naval squadron operated against American shipping in the Mediterranean. In one attack an American Merchantman was captured and its crew imprisoned. In March, 1815, Congress passed an act that authorized the use of armed vessels "as may be judged requisite by the President" to provide effective protection to American commerce in the Atlantic and the Mediteranean. A naval squadron of 10 vessels under Commodore Decatur attacked Algiers, compelling the Dey to negotiate a treaty. Decatur also demonstrated at Tunis and Tripoli. All three states were forced to pay for losses to American shipping, and the threats and tribute terminated.

1816- Spanish Florida -- United States forces destroyed Nicholls Fort, also called Negro Fort, which harbored raiders into United States territory.

1816-1818-- Spanish Florida -- First Seminole War -- The Seminole Indians, whose area was a resort for escaped slaves and border ruffians, were attacked by troops under Generals Jackson and Gaines and pursued into northern Florida. Spanish posts were attacked and occupied, British citizens executed. There was no declaration or congressional authorization but the Executive was sustained.

1817- Amelia Island (Spanish territory off Florida) -- Under orders of President Monroe, United States forces landed and expelled a group of smugglers, adventurers, and freebooters.

1818- Oregon -- The U.S.S. Ontario, dispatched from Washington, landed at the 
Columbia River and in August took possession. Britain had conceded sovereignty but Russia and Spain asserted claims to the area.

1820-1822-- West Coast of South America -- 1820 to May, 1822 -- Marines were aboard three of the U.S. ships stationed off the west coast of South America between these dated to protect American commerce during the revolt against Spain.

1820-1823- Africa - Naval units raided the slave traffic pursuant to the 1819 act of Congress.

1822- Cuba -- United States naval forces suppressing piracy landed on the northwest coast of Cuba and burned a pirate station.

1823- Cuba -- Brief landing in pursuit of pirates occurred April 8 near Escondido; April 16 near Cayo Blanco; July 11 at Siquapa Bay; July 21 at Cape Cruz; and October 23 at Camrioca.

1824- Cuba -- In October the U.S.S. Porpoise landed bluejackets near Matanzas in pursuit of pirates. This was during the cruise authorized in 1822.

1824- Puerto Rico -- Commodore David Porter with a landing party attacked the town of Fajardo which had sheltered pirates and insulted American naval officers. He landed with 200 men in November and forced an apology.

1825- Cuba -- In March cooperating American and British forces landed at Sagua La Grande to capture pirates.

1827-Greece -- In October and November landing parties hunted pirates on the islands of Argenteire, Miconi, and Andross.

1828- West Indies - December - Acting pursuant to legislation, Marines participated in the capture of the Argentinean privateer Federal by the U.S. sloop Eric.

1830- Haiti -- June 5 -- Marines participated in the capture of the slave brig Fenix by the U.S. schooner Grampus off Cape Haftien, Haiti. 
1831-1832-- Falkland Islands -- To investigate the capture of three American sailing vessels and to protect American interests.

1832- Sumatra - February 6 to 9 -- To punish natives of the town of Quallah Battoo for depredations on American shipping.

1833- Argentina -- October 31 to November 15 -- A force was sent ashore at Buenos Aires to protect the interests of the United States and other countries during an insurrection.

1835- Samoa -- October 11 -- Eighty marines and sailors burned the principal village on the island to avenge harsh treatment meted out to American seamen.

1835-1836-- Peru -- December 10, 1835 to January 24, 1836, and August 31 to December 7, 1836 -- Marines protected American interests in Callao and Lima during an attempted revolution.

1836 - Mexico -- Gen. Gaines occupied Nacohdoches (Tex.), disputed territory from July to December during the Texan war for independence, under orders to cross the "imaginary boundry line" if an Indian outbreak threatened.

1838-1839-- Sumatra -- December 24, 1838 to January 4, 1839 -- To punish natives of the towns of Quallah Battoo and Muckie (Mukki) for depredations on American shipping.

1840- Fiji Islands -- July -- To punish natives for attacking American exploring and survey parties.

1841- Samoa -- February 25 -- An American force of 70 marines and seamen from the U.S.S. Peacock landed to avenge the murder of a seaman. They burned three villages.

1841- Drummond Island, Kingsmill Group -- To avenge the murder of a seaman by the natives. 
1842- Mexico -- Commodore T.A. Jones, in command of a squadron long cruising off California, occupied Monterey, California on October 19, believing war had come. He discovered peace, withdrew, and saluted. A similar incident occurred a week later at San Diego.

1843- China -- Sailors and marines from the St. Louis were landed after a clash between Americans and Chinese at the trading post in Canton.

1843-Africa -- November 29 to December 16 -- Four United States vessels demonstrated and landed various parties (one of 200 marines and sailors) to discourage piracy and the slave trade along the Ivory Coast, etc., and to punish attacks by the natives on American seamen and shipping.

1844- China -- June 18 -- Marines from the U.S. sloop St. Louis went ashore at Canton, China to protect American lives.

1844- Mexico -- President Tyler deployed U.S. forces to protect Texas against Mexico, pending Senate approval of a treaty of annexation. (Later rejected.) He defended his action against a Senate resolution of inquiry.

1845- African coast -- November 30 -- Marines joined in the capture of the slave bark Pons by the U.S. sloop Yorktown off Kahenda, Africa. The action was consistent with a treaty of 1842 .

****1846-1848--Mexico, the Mexican War -- President Polk's occupation of disputed territory precipitated it. War formally declared.

1849- Smyrna -- In July a naval force gained release of an American seized by Austrian officials.

1850- African coast -- June 6 -- Marines joined in capturing a slave ship by the U.S. brig Perry off Luanda, Africa. The action was consistent with the treaty of 1842 .

1851- Turkey -- After a massacre of foreigners (including Americans) at Jaffa in January a demonstration by the Mediterranean Squadron was ordered 
along the Turkish (Levant) coast. Apparently no shots fired.

1851- Johanna Island (east of Africa), August -- To exact redress for the unlawful imprisonment of the captain of an American whaling brig.

1852-1853--Argentina -- February 3 to 12, 1852; September 17, 1852 to April 1853 -- Marines landed and maintained in Buenos Aires to protect American interests during a revolution.

1853- Nicaragua -- March 11 to 13 -- To protect lives and interests during political disturbances.

1853-1854--Japan -- The "opening of Japan" and the Perry Expedition.

1853-1854--Ryukyu and Bonin Islands -- Commodore Perry on three visits before going to Japan and while waiting for a reply from Japan made a naval demonstration, landing Marines twice, and secured a coaling concession from the ruler of Naha on Okinawa. He also demonstrated in the Bonin Islands. All to secure facilities for commerce.

1853- China -- September 11 -- Small marine force from the U.S. steamer Mississippi boarded a Siamese vessel in the Canton River and put down a mutiny.

1853- West Coast of Africa -- December 3 -- In accordance with the Treaty of 1842 Marines joined in the capture of the slave schooner Gambrill by the U.S. frigate Constitution off the Congo River on the west coast of Africa.

1854- China -- April 4 to June 15 to 17 -- To protect American interests in and near Shanghai during Chinese civil strife.

1854- Nicaragua -- July 9 to 15 -- San Juan del Norte (Greytown) was destroyed to avenge an insult to the American Minister to Nicaragua.

1854- West Coast of Africa -- March 10 -- Pursuant to the Treaty of 1842, Marines joined in the capture of a slave brig by the U.S. brig Perry off the 
west coast of Africa.

1854- Okinawa -- July 6 -- A force of 20 marines from the U.S. steamer Powhaten went ashore on Okinawa and seized a religious shrine in punishment of persons who murdered an American.

1855- Uruguay -- November 25 to 29 or 30 -- United States and European naval forces landed to protect American interests during an attempted revolution in Montevideo.

1855- China -- There were two brief actions by U.S. warships, the first a landing in May at Shanghai to protect American interests there, the second an attack in August at Hong Kong against pirates.

1855- Fiji Islands -- September and October -- Marines from the sloop-of-war John Adams landed four times to seek reparations for depredations against Americans and to force natives to honor a treaty. The landing parties fought skirmishes and burned some villages.

1856- Panama, Republic of New Grenada -- September 19 to 22 -- To protect American interests during an insurrection.

1856- China -- October 22 to December 6 -- To protect American interests at Canton during hostilities between the British and the Chinese; and to avenge an unprovoked assault upon an unarmed boat displaying the United States flag.

1857- Nicaragua -- April to May, November to December -- To oppose William Walker's attempt to get control of the country. In May Commander C.H. Davis of the United States Navy, with some Marines, received Walker's surrender and protected his men from the retaliation of native allies who had been fighting Walker. In November and December of the same year United States vessels Saratoga, Wabash, and Fulton opposed another attempt of William Walker on Nicaragua. Commodore Hiram Paulding's 
act of landing Marines and compelling the removal of Walker to the United States, was tacitly disavowed by Secretary of States Lewis Cass, and Paulding was forced into retirement.

1858- Uruguay -- January 2 to 27 -- Forces from two United States warships landed to protect American property during a revolution in Montevideo.

1858- Fiji Islands -- October 6 to 16 -- To chastise the natives for the murder of two American citizens.

1858- African coast -- September 8 -- Marines joined in the capture of a ketch laden with slave food by the U.S. sloop Marion off the southeast coast of Africa. The action was consistent with the Treaty of 1842 .

1858- Cuban waters -- After repeated acts of British cruisers in boarding and searching our merchant vessels in the Gulf of Mexico and adjacent seas, President Buchanan addressed remonstrances to the British government against these searches and, without authority from Congress, ordered a naval force to the Cuban waters with directions "to protect all vessels of the United States on the high seas from search or detention by the vessels of war of any other nation." A conflict with Great Britain was avoided only by its abandonment of her claim to the right of visit and search in tirne of peace.

1858-1859--Turkey -- Display of naval force along the Levant at the request of the Secretary of State after massacre of Americans at Jaffa and mistreatment elsewhere "to remind authorites (of Turkey) *** of the power of the United States".

1859- Paraguay -- Congress authorized a naval squadron to seek redress for an attack on a naval vessel in the Parana River during 1855. Apologies were made after a large display of force.

1859- Mexico -- Two hundred United States soldiers crossed the Rio Grande in 
pursuit of the Mexican bandit Cortina.

1859- China - July 31 to August 2 -- For the protection of American interests in Shanghai.

1859- African coast -- April 21 and 27 -- Marines joined in capture of a slave ship near the Congo River, Africa. The action was consistent with the Treaty of 1842 .

1860- Angola a Portuguese West Africa -- March 1 -- To protect American lives and property at Kissenbo when the natives became troublesome.

1860- Colombia, Bay of Panama -- September 27 to October 8 -- To protect American interests during a revolution.

1863- Japan -- July 16 -- To redress an insult to the American flag -- firing on an American vessel -- at Shimonoseki.

1864- Japan -- July 14 to August 3, approximately -- to protect the United States Minister to Japan when he visited Yedo to negotiate concerning some American claims against Japan, and to make his negotiations easier by impressing the Japanese with American power.

1864- Japan -- September 4 to 14 -- Straits of Shimonoseki -- To compel Japan and the Prince of Nagato in particular to permit the Straits to be used by foreign shipping in accordance with treaties already signed.

1865- Panama -- March 9 and 10 -- To protect the lives and property of American residents during a revolution.

1865-1866--Mexican border -- In late 1865, Gen. Sheridan was dispatched to the Mexican border with 50,000 troops to back up the protest made by Secretary of State Seward to Napoleon III that the presence of over 25,000 French troops in Mexico "is a serious concern to the United States." In February, 1866, Seward demanded a definite date be set for withdrawal and France complied. Though American forces did not cross 
the border, the threat of foreign military operations was clear and imminent.

1866- Mexico -- To protect American residents, Gen. Sedgwick and 100 men in November obtained surrender of Matamoras. After 3 days he was ordered by U.S. Government to withdraw. His act was repudicated by the President.

1866- China -- June 20 to July 7 -- To punish an assault on the American counsul at Newchwang; July 14, for consultation with authorities on shore; August 9, at Shanghai, to help extinguish a serious fire in the city.

1867- Nicaragua -- Marines occupied Managua and Leon.

1867- Island of Formosa -- June 13 -- To punish a horde of savages who were supposed to have murdered the crew of a wrecked American vessel.

1868- Japan (Osaka, Hiogo, Nagasaki, Yokhama, and Negata) -- Mainly, February 4 to 8, April 4 to May 12, June 12 and 13 -- To protect American interests during the civil war in Japan over the abolition of the Shogunate and the restoration of the Mikado.

1868- Uruguay -- February 7 and 8, 19 to 26 -- To protect foreign residents and the customhouse during an insurrection in Montevideo.

1868- Columbia -- April 7 -- at Aspinwall - To protect passengers and treasure in transit during the absence of local police or troops on the occasion of the death of the President of Columbia.

1869-1871--Dominican Republic -- President Grant, having negotiated a treaty of annexation, sent a strong naval force to the island to protect it from invasion and internal disorder, both during consideration of the treaty by the Senate and for months after its rejection.

1870- Mexico -- June 18 and 19 -- To destroy the pirate ship Forward, which had been run aground about 40 miles up the Rio Tecapan. 
1870- Hawaiian Islands -- September 21 -- To place the American flag at half mast upon the death of Queen Kalama, when the American counsel at Honolulu would not assume responsibility for so doing.

1871- Korea - June 10 to 12 -- To punish natives for depredations on Americans, particularly for murdering the crew of the General Sherman and burning the schooner, and for late firing on other American small boats taking soundings up the Salee River.

1873- Columbia (Bay of Panama) - May 7 to 22, September 23 to October 9 -- To protect American interests during hostilities over possession of the government of the State of Panama.

1873- Mexico -- United States troops crossed the Mexican border repeatedly in pursuit of cattle and other thieves. There were some reciprocal pursuits by Mexican troops into border territory. The cases were only technically invasions, if that, although Mexico protested constantly. Notable cases were at Remolina in May 1873 and at Las Cuevas in 1875. Washington orders often supported these excursions. Agreements between Mexico and the United States, the first in 1882, finally legitimized such raids. They continued intermittently, with minor disputes, until 1896.

1873- Cuban water -- October 31 -- The steamer Virginia, flying the American flag, was captured some 18 miles from Jamaica by the Spanish steamer Tornado, her actual destination having been to make a landing of men and arms in Cuba. In violation of treaty stipulations with the U.S. regarding counsel and trial before a proper court, a summary court-martial was convened and with circumstancs of the utmost barbarity, a total of 53 of the crew and passengers were executed, including a considerable number of Americans. Large meetings were held in this country demanding violent action against Spain and the President authorized the Secretary of 
the Navy to put our navy on a war footing. Every available ship was commissioned or recalled from foreign stations and war looked imminent. Spain yielded and the Virginia with her surviving crew and passengers were returned in late December. Also, by an agreement concluded February 27,1875 , Spain admitted the illegality of the capture and the wrongfulness of the summary executions and paid an indemnity of $\$ 80,000$ to the United States.

1874- Hawaiian Islands -- February 12 to 20 -- To preserve order and to protect American lives and interests during the coronation of a new king.

1876- Mexico -- May 18 -- To police the town of Matamoras temporarily while it was without other government.

1882- Egypt -- July 14 to 18 -- To protect American interests during warfare between British and Egyptians and looting of the city of Alexandria by Arabs.

1885- Panama (Colon) -- January 18 and 19 -- To guard the valuables in transit over the Panama Railroad, and the safes and vaults of the company during revolutionary activity. In March, April, and May in the cities of Colon and Panama City, to reestablish freedom of transit during revolutionary activity.

1888- Korea -- June -- To protect American residents in Seoul during unsettled political conditions, when an outbreak of the populace was expected.

1888- Haiti -- December 20 -- To persuade the Haitian Government to give up an American steamer which had been seized on the charge of breach of blockade.

1888-1889--Samoa -- November 14, 1888 to March 20, 1889 -- To protect American citizens and the consulate during a native civil war.

1889- Hawaiian Islands - July 30 and 31 -- To protect American interests at 
Honolulu during a revolution.

1890- Argentina - A naval party landed to protect U.S. consulate and legation in Buenos Aires.

1891- Haiti - To protect American lives and property on Navassa Island.

1891- Bering Sea -- July 2 to October 5 -- To stop seal poaching.

1891-Chile -- August 28 to 30 -- To protect the American consulate and the women and children who had taken refuge in it during a revolution in Valparaiso.

1893- Hawaii - January 16 to April 1 -- Ostensibly to protect American lives and property; actually to promote a provisional government under Sanford B. Dole. This action was disavowed by the United States.

1894- Brazil - January -- To protect American commerce and shipping at Rio de Janeiro during a Brazilian civil war. No landing was attempted but there was a display of naval force.

1894- Nicaragua -- July 6 to August 7 -- To protect American interests at Bluefields following a revolution.

1894-1895--China -- Marines were stationed at Tientsin and penetrated to Peking for protection purposes during the Sino-Japanese War.

1894-1895--China -- Naval vessel beached and used as a fort at Newchwang for protection of American nationals.

1894-1896--Korea -- July 24, 1894 to April 3, 1896 -- To protect American lives and interests at Seoul during and following the Sino-Japanese War. A guard of marines was kept at the Amreican legation most of the time until April 1896.

1895- Colombia -- March 8 and 9 -- To protect American interests during an attack on the town of Bocas del Toro by a bandit chieftain.

1896- Nicaragua -- May 2 to 4 - To protect American interests in Corinto during 
political unrest.

1898- Nicaragua - February 7 and 8 -- To protect American lives and property at San Juan del Sur.

****1898- Spain -- The Spanish-American War. Fully declared.

1898-1899--China -- November 5, 1898 to March 15, 1899 -- To provide a guard for the legation at Peking and the consulate at Tientsin during contest between the Dowager Empress and her son.

1899- Nicaragua -- To protect American interests at San Juan del Norte, February 22 to Marh 5, and at Bluefields a few weeks later in connection with the insurrection of Gen. Juan P. Reyes.

1899- Samoa -- March 13, to May 15 -- To protect American interests and to take part in a bloody contention over the succession to the throne.

1899-1901--Philippine Islands -- To protect American interests following the war with Spain, and to conquer the islands by defeating the Filipinos in their war for independence.

1900- China -- May 24 to September 28 -- To protect foreign lives during the Boxer uprising, particularly at Peking. For many years after this experience a permanent legation guard was maintained in Peking, and was strengthened at times as trouble threated. It was still there in 1934.

1901 - Colombia (State of Panama) -- November 20 to December 4 -- To protect American property on the Isthmus and to keep transit lines open during serious revolutionary disturbances.

1902- Colombia (State of Panama) -- April 16 to 23 -- To protect American lives and property at Bocas del Toro during a civil war.

1902- Colombia (State of Panama) -- September 17 to November 18 -- To place armed guards on all trains crossing the Isthmus to keep the railroad lines open. 
1903- Honduras -- March 23 to 30 or 31 -- To protect the Amreican consulate and the steamship wharf at Puerto Cortez during a period of revolutionary activity.

1903- Dominican Republic -- March 30 to April 21 -- To protect American interests in the city of Santo Domingo during a revolutionary outbreak.

1903- Syria - September 7 to 12 -- To protect the American consulate in Beirut when a local Moslem uprising was feared.

1903-1904--Abyssinia -- Twenty-five marines were sent to Abyssinia to protect the U.S. Counsel General while he negotiated a treaty.

1903-1914--Panama -- To protect American interests and lives during and following the revolution for independence from Colombia over construction of the Isthian Canal. With brief intermissions, United States Marines were stationed on the Isthmus from November 4, 1903, to January 21,1914 , to guard American interests.

1904- Dominican Republic -- January 2 to February 11 -- To protect American interests in Puerto Plata and Sosua and Santo Domingo City during revolutionary fighting.

1904- Tangier, Morocco -- "We want either Perdicaris alive or Raisula dead." Demonstration by a squadron to force release of a kidnaped American. Marine guard landed to protect consul general.

1904- Panama -- November 17 to 24 -- To protect American lives and property at Ancon at the time of a threatened insurrection.

1904-1905--Korea -- January 5, 1904 to November 11, 1905 -- To guard the American Legation in Seoul.

1904-1905--Korea -- Marine guard sent to Seoul for protection during the RussoJapanese War.

1905-1907--Dominican Republic -- After the Senate failed to ratify a treaty 
providing that the United States should guarantee the integrity of the Dominican Republic, take charge of its customs, and settle its obligations, President Roosevelt nevertheless put its terms into effect for two years until in 1907 the Senate ratified a slightly revised version.

1906-1909--Cuba -- September 1906 to January 23, 1909 -- Intervention to restore order, protect foreigners, and establish a stable government after serious revolutionary activity.

1907- Honduras -- March 18 to June 8 -- To protect American interests during a war between Honduras and Nicaragua; troops were stationed for a few days or weeks in Trujillo, Ceiba, Puerto Cortez, San Pedro, Laguna and Choloma.

1910- Nicaragua -- February 22 -- During a civil war, to get information of conditions at Corinto; May 19 to September 4, to protect American interests at Bluefields.

1911- Honduras -- January 26 and some weeks thereafter -- To protect American lives and interests during a civil war in Honduras.

1911- China -- Approaching stages of the nationalist revolution. An ensign and 10 men in October tried to enter Wuchang to rescue missionaries but retired on being warned away.

A small landing force guarded American private property and consulate at Hankow in October.

A Marine guard was established in November over the cable stations at Shanghai.

Landing forces were sent for protection in Nanking, Chinkkaing, Taku and elsewhere.

1912- Honduras -- Small force landed to prevent seizure by the Government of an American-owned railroad at Puerto Cortez. Forces withdrawn after 
the United States disapproved the action.

1912- Panama - Troops, on request of both political parties, supervised elections outside the Canal Zone.

1912- Cuba -- June 5 to August 5 -- To protect American interests on the Province of Oriente, and in Havana.

1912- China -- August 24 to 26, on Kentucky Island, and August 26 to 30 at Camp Nicholson -- To protect Americans and American interests during revolutionary activities.

1912- Turkey -- November 18 to December 3 - To guard the American Legation at Constantinople during a Balkan War.

1912-1941--China -- The disorders which began with the Kuomintang rebellion in 1912, which were redirected by the invasion of China by Japan and finally ended by war between Japan and the United States in 1941, led to demonstrations and landing parties for the protection of U.S. interests in China continuously and at many points from 1912 to 1941 . The guard at Peking and along the route to the sea was maintained until 1941. In 1927, the United States had 5,670 troops ashore in China and 44 naval vessels in its waters. In 1933 U.S. had 3,027 armed ashore. All this protective action was in general terms based on treaties with China ranging from 1858 to 1901 .

1913- Mexico -- September 5 to 7 -- A few marines landed at Claris Estero to aid in evacuating American citizens and others from the Yaqui Valley, made dangerous for foreigners by civil strife.

1914- Haiti -- January 29 to February 9, February 20 to 21 , October 19 -- To protect American nationals in a time of dangerous unrest.

1914- Dominican Republic - June and July -- During a revolutionary movement, United States naval forces by gunfire stopped the bombardment of Puerto Plata, and by threat of force maintained Santo Domingo as a neutral zone. 
1914-1917-Mexico - The undeclared Mexican-American hostilities following the Dolphin affair and Villa's raids included capture of Vera Cruz and later Pershing's expedition into northern Mexico.

1915- Dominican Republic -- August 15 -- The 5th Marine Regiment arrived at Puerto Plata to protect American lives and property during a revolutionary outbreak. Their protective missions lasted until October 12, 1915.

1915-1934--Haiti -- July 28, 1915 to August 15, 1934 -- To maintain order during a period of chronic and threatened insurrection.

1916- China - American forcs landed to quell a riot taking place on American property in Nanking.

1916-1924--Dominican Republic -- May 1916 to September 1924 -- To maintain order during a period of chronic and threatened insurrection.

1917- China -- American troops were landed at Chungking to protect American lives during a political crisis.

****1917-1918--World War I. Fully declared.

1917-1922--Cuba -- To protect American interests during an insurrection and subsequent unsettled conditions. Most of the United States armed forces left Cuba by August 1919, but two companies remained at Camaguey until February 1922.

1917-Armed Atlantic Merchant Ships -- February - President Wilson asked Congress for authority to arm U.S. merchant vessels with defensive guns, but Congress refused to pass such a law, thereupon Wilson acted, on his own authority, to equip American merchant vessels with guns and gunners assigned to them from the Navy. The action occurred prior to the declaration of war on Germany which did not take place until April 6, 1917. 
1918-1919-=-Mexico - After withdrawal of the Pershing Expedition, our troops entered Mexico in pursuit of bandits at least three times in 1918 and six in 1919. In August 1918 American and Mexican troops fought at Nogales.

1918-1920-Panama -- For police duty according to treaty stipulations, at Chiriqui, during election disturbancs and subsequent unrest.

1918-1920--Soviet Russia -- Marines were landed at and near Vladivostok in June and July to protect the American consulate and other points in the fighting between the Bolsheviki troops and the Czech Army which had traversed Siberia from the western front. A joint proclamation of emergency government and neutrality was issues by the American, Japanese, British, French, and Czech commanders in July and our party remained until late August.

In August the project expanded. Then 7,000 men were landed in Vladivostok and remained until January 1920, as part of an allied occupation force.

In September 1918, 5,000 American troops joined the allied intervention force at Archangel, suffered 500 casualties and remained until June 1919. A handful of Marines took part earlier in a British landing on the Murman coast (near Norway) but only incidently.

All these operations were to offset effects of the Bolsheviki revolution in Russia and were partly supported by Czarist or Kerensky elements. No war was declared. Bolsheviki elements participated at times with us but Soviet Russia will claim damages.

1919- Dalmatia -- U.S. forces were landed at Trau at the request of Italian authorities to police order between the Italians and Serbs.

1919- Turkey - Marines from the U.S.S. Arizona were landed to guard the U.S. Consulate during the Greek occupation of Constantinople. 
1919- Honduras -- September 8 to 12 -- A landing force was sent ashore to maintain order in a neutral zone during an attempted revolution.

1920- China -- March 14 -- A landing force was sent ashore for a few hours to protect lives during a disturbance at Kuikiang.

1920- Guatemala - April 9 to 27 -- To protect the American Legation and other American interests, such as the cable station, during a period of fighting between Unionists and the Government of Guatemala.

1920-1922--Russia (Siberia) -- February 16, 1920 to November 19, 1922 -- A marine guard to protect the United States radio station and property on Russian Island, Bay of Vladivostok.

1921- Panama-Costa Rica - American naval squadrons demonstrated in April on both sides of the Isthmus to prevent war between the two countries over a boundry dispute.

1922- Turkey -- September and October -- A landing force was sent ashore with consent of both Greek and Turkish authorites, to protect American lives and property when the Turkish Nationalists entered Smyrna.

1922-1923--China - Between April 1922 and November 1923 Marines were landed five times to protect Americans during periods of unrest.

1924- Honduras -- February 28 to March 31, September 10 to 15 -- To protect American lives and interests during election hostilities.

1924- China -- September -- Marines were landed to protect Americans and other foreigners in Shanghai during Chinese factional hostilities.

1925- China - January 15 to August 29 -- Fighting of Chinese factions accompanied by riots and demonstrations in Shanghai necessitated landing American forces to protect lives and property in the International Settlement. 
1925- Honduras -- April 19 to 21 - To protect foreigners at La Ceiba during a political upheaval.

1925- Panama - October 12 to 23 - Strikes and rent riots led to the landing of about 600 American troops to keep order and protect American interests.

1926- China -- August and September -- The Nationalist attack on Hankow necessitated the landing of American naval forces to protect American citizens. A small guard was maintained at the consulate general even after September 16, when the rest of the forces were withdrawn. Likewise, when Nationalist forces captured Kiukiang, naval forces were landed for the protection of foreigners November 4 to 6 .

1926-1933--Nicaragua -- May 7 to June 5, 1926; August 27, 1926 to January 3, 1933 -- The coup d'etat of Gen. Chamorro aroused revolutionary activities leading to the landing of American marines to protect the interests of the United States. United States forces came and went,but seem not to have left the country entirely until January 3, 1933. Their work included activity against the outlaw leader Sandino in 1928.

1927- China - February - Fighting at Shanghai caused American naval forces and marines to be increased there. In March a naval guard was stationed at the American consulate at Nanking after Nationalist forces captured the city. American and British destroyers later used shell fire to protect Americans and other foreigners. Following this incident additional forces of marines and naval vessels were ordered to China and stationed in the vicinity of Shanghai and Tientsin.

1932- China - American forces were landed to protect American interests during the Japanese occupation of Shanghai.

1933- Cuba -- During a revolution against President Gerardo Machado naval forces demonstrated but no landing was made. 
1934- China - Marines landed at Foochow to protect the American consulate.

1936- Spain -- July 27 to September 19 -- The Quincy, carrying marine guard, served in the Spanish war zone. The vessel touched at several ports, sometimes evacuating American nationals.

1940- Newfoundland, Bermuda, St. Lucia, Bahamas, Jamaica, Antigua, Trinidad, and British Guiana - Troops were sent to guard air and naval bases obtained by negotiation with Great Britain. These were sometimes called lend-lease bases and were obtained through the destroyer deal with Great Britain.

1941- Greenland - Taken under protection of the United States in April.

1941- Netherlands (Dutch Guiana) -- In November the President ordered American troops to occupy Dutch Guiana but by agreement with the Netherlands government in exile, Brazil cooperated to protect aluminum ore supply from the bauxite mines in Surinam.

1941- Iceland - Taken under the protection of the United States, with consent of its government, for strategic reasons.

1941-Germany -- Sometime in the spring the President ordered the Navy to patrol ship lanes to Europe. By July U.S. warships were convoying and by September were attacking German submarines. There was no authorization of Congress or declaration of war. In November, the Neutrality Act was partly repealed.

****1941-1945--Germany, Italy, Japan, etc. -- World War II. Fully declared.

1946- Trieste - President Truman ordered the augmentation of U.S. troops along the zonal occupation line and the reinforcement of air forces in northern Italy after Yugoslav forces shot down an unarmed U.S. Army transport plane flying over Venezia Giulia. Earlier U.S. naval units had been dispatched to the scene. 
1946- Turkey - August 7 -- Russia demanded that Turkey allow it to participate in the defense of the Straits. On August 14, President Truman met with his chief advisers and approved their recommendation to send a power naval force, including the supercarrier Franklin D. Rosevelt, to join the U.S.S. Missouri at Istanbul as an affirmation of U.S. intentions to resist the Russian move against Turkey and the Straits. Truman informed his advisers that he understood fully that the action could lead to war, but nevertheless he was determined to prevent Soviet domination of the area.

1946- Greece - September -- During the attempted Communist takeover of Greece, naval units were requested by the U.S. Ambassador. One carrier was on the scene.

1948- Palestine - A marine consular guard was sent to Jerusalem to protect the U.S. Consular General.

1948- Mediterranean -- January 7 -- Fleet Admiral Nimitz implied marine reinforcements sent from the U.S. to Mediterranean waters served as a warning to Yugoslavia that the 5,000 U.S. Army troops in Trieste were not to be molested.

1948-1949--China -- Marines were dispatched to Nanking to protect the American Embassy when the city fell to Communist troops, and to Shanghai to aid in the protection and evacuation of Americans.

1950-1953-Korea - U.S. responded to North Korean invasion of South Korea by going to its assistance, pursuant to United Nations Security Council resolution. Congressional authorization was not sought and actual order for moving American troops was given before U.N. resolution was considered.

1954-1955-China - Naval units evacuated U.S. civilians and military personnel from the Tachen Islands. 
1956- Egypt -- A marine battalion evacuated U.S. nationals and other persons from Alexandria during the Suez crisis.

1957- Indonesia -- February 14 -- The 3rd Marines took up station 550 miles northeast of Sumatra ready to intervene to protect U.S. nationals during the Indonesian revolt.

1957- Taiwan -- July -- During shelling of Kinmen Island, naval units were dispatched to defend Taiwan. Four carriers were on the scene.

1958- Lebanon -- Marines were landed in Lebanon at the invitation of its government to help protect against threatened insurrection supported from the outside.

1958- Venezuela -- January -- When mob violence erupted in Caracas, a company of marines embarked on board the U.S.S. Des Moines and remained on station off Venezuela ready to protect American interests.

1958- Indonesia -- March -- A marine company, attack squadron, and helicopter squadron were deployed with elements of the Seventh Fleet off Indonesia prepared to protect U.S. citizens and interests.

1959-1960-The Caribbean -- 2nd Marine Ground Task Force was deployed to protect U.S. nationals during the Cuban crisis.

1961- Show of Naval Force in Dominican Waters -- May to November -- On May 30, Dominican dictator Rafael Trujillo was assassinated. Political conditions in the Dominican Republic deterioratd during the summer and early autumn. Then, on November 15, Gen. Hector Trujillo and Gen. Jose Trujillo, brothers of the slain dictator returned to the island. Secretary Rusk stated three days later they appeared "to be planning an attempt to reassert the dictatorial domination of the political and economic life of the country." He added: "the United States is considering the further measures that unpredictable events might warrant." 
On November 19, U.S. Navy ships took up positions three miles off the Dominican coast and Navy jet planes patrolled the shoreline. The show of force produced the desired result because the Trujillo brothers and other members of the family departed for Miami before the day was over. According to one authority, "It later transpired that the Kennedy Administration was prepared to order U.S. marines ashore if President Joaquin Balaguer had so requested or if the Trujillos had ousted Balaguer from the presidency.

1962- Cuba -- President Kennedy instituted a "quarantine" on the shipment of offensive missiles to Cuba from the Soviet Union. He also warned the Soviet Union that the launching of any missile from Cuba against any nation in the Western Hemisphere would bring about U.S. nuclear retaliation on the Soviet Union. A negotiated settlement was achieved in a few days.

1962- Thailand -- The 3rd Marine expeditionary Unit landed on May 17, 1962 to support that country during the threat of Communist pressure from outside; by July 30 the 5,000 marines had been withdrawn.

1962-1975-Laos -- From October 1962 until 1975, the United States played a role of military support in Laos.

1963- Haiti -- May 4 -- A Marine battalion was positioned off the coast of Haiti for five days when trouble developed in that country.

1964- Congo -- The United States sent four transport planes to provide airlift for Congolese troops during a rebellion and to transport Belgian paratroopers to rescue foreigners.

1964-1973--Vietnam -- U.S. military advisers had been in South Vietnam for a dcade, and their numbers had been increased as military position of Saigon government became weaker. After the attacks on U.S. destroyers in the 
Tonkin Gulf, President Johnson asked for a resolution expressing U.S. determination to support freedom and protect peace in Southeast Asia. Congress responded with the Tonkin Gulf Resolution, expressing support for "all necessary measures" the President might take to repel armed attack against U.S. forces and prevent further aggression. Following this resolution, and following a communist attack on a U.S. installaion in central Vietnam, the U.S. escalated its participation in the war.

1965- Dominican Republic - Intervention to protect lives and property during a Dominican revolt. More troops were sent as the U.S. feared the revolutionary forces were coming increasingly under Communist control.

1967- Syrian Coast -- June -- During the Arab-Israeli War, President Johnson ordered the U.S. 6th Fleet to move to within 50 miles of the Syrian coast as a message to the Soviet Union it "would have to deal with us" if it entered to conflict. The action was taken as a counter move against the Soviet Union after Premier Kosygn told President Johnson over the hotline that the Soviets had reached an "independent decision" that they were prepared to take "necessary action, including military" to stop the advance of Israeli troops into Arab territory, and would give the Israeli troops just five hours to unconditionally halt their operations.

1967- Congo -- The United States sent three military transport aircraft with crews to provide the Congo central government with logistical support during a revolt.

1970- Jordanian-Syrian Crisis -- September -- On September 17, King Hussein of Jordan moved against Palestinian guerrillas in an effort to reassert the royal authority. Despite a warning by President Nixon, talking to newspaper editors in Chicago, that the U.S. might intervene if Syria or Iraq threatened King Hussein's government, some 300 Syrian tanks crossed 
into Jordan during the next three days. Secretary Rogers condemned the Syrian invasion and the U.S. called on the Soviet Union to use its influence to persuade Syria to pull out.

President Nixon moved the Sixth Fleet off the Israeli-Lebanese coast and publicity was given to the dispatch of the helicopter carrier Guam with 1,500 marines to join the fleet, to the alert of the 82nd Airborne Division in Fort Bragg, N.C., and to the alert of two airborne battalions of the 8th Infantry Division in West Germany. At the same time the Israelis began a partial mobilization and movements of tanks toward the northern part of the Jordan River Valley in position to attack the Syrian invaders. The U.S. apparently was prepared to intervene militarily, in coordination with the Israelis', to prevent the overthrow of King Hussein's government and to rescue 38 American hostages known to be in the hands of Palestinian guerrillas. By September 22, Syrian tanks began withdrawing and on September 25, the crisis ended when King Hussein and Yasir Arafat, the guerrilla chief, agreed on a cease-fire.

1970- Cambodia -- U.S. troops were ordered into Cambodia to clean out Communist sanctuaries from which Viet Cong and North Vietnamese attacked U.S. and South Vietnamese forces in Vietnam.

1971- Indo-Pakistan War -- March through December -- During war between Pakistan and India for control of East Pakistan (Bangladesh), President Nixon ordered large elements of naval forces into th Indian Ocean area mainly to provide assurance to the Pakistani government and as a threat to the Indian-Russian alliance.

1974- Evacuation from Cyprus -- United States Naval forces evacuated U.S. civilians during hostilities between Turkish and Greek Cypriot forces. 
1975- Evacuation from Vietnam -- U.S. naval vessels, helicopters and marines were sent to assist in evacuation of refugees and U.S. nationals from Vietnam.

1975- Evacuation from Cambodia -- President Ford ordered U.S. military forces to proceed with the planned evacuation of U.S. citizens from Cambodia.

1975- Mayaguez incident -- President Ford ordered military forces to retake the SS Mayaguez, a merchant vessel en route from Hong Kong to Thailand with a U.S. citizen crew which was seized by Cambodian naval patrol boats in international waters and forced to proceed to a nearby island.

* Information compiled from War Powers hearing of 93rd Congress, 1st session, p. 328-363 and committee print entitled "Background Information on the Use of U.S. Armed Forces in Foreign Countries 1975 Revision," 94th Congress, 1st session, p. 58-66. 


\section{APPENDIX II}

Public Law 93-148

War Powers Resolution

Concerning the war powers of Congress and the President.

Section 1. This joint resolution may be cited as the "War Powers Resolution."

Purpose and Policy

Section 2. (a) It is the purpose of this joint resolution to fulfill the intent of the framers of the Constitution of the United States and insure that the collective judgment of both the Congress and the President will apply to the introduction of United States Armed Forces into hostilities, or into situations where imminent involvement in hostilities is clearly indicated by the circumstances, and to the continued use of such forces in hostilities or in such situations.

(b) Under article I, section 8, of the Constitution, it is specifically provided that the Congress shall have the power to make all laws necessary and proper for carrying into execution, not only its own powers but also all other powers vested by the Constitution in the Government of the United States, or in any department or officer thereof.

(c) The constitutional powers of the President as Commander-in-Chief to introduce United States Armed Forces into hostilities, or into situations where imminent involvement in hostilities is clearly indicated by the circumstances, are exercised only pursuent to (a) a declaration of war, (2) specific statutory authorization, or (3) a national emergency created by attack upon the United States, its territories or possessions, or its armed forces. 
Consultation

Section 3. The President in every possible instance shall consult with Congress before introducing United States Armed Forces into hostilities or into situations where imminent involvement in hostilities is clearly indicated by the circumstances, and after every such introduction shall consult regularly with the Congress until United States Armed Forces are no longer engaged in hostilities or have been removed from such situations.

Reporting

Section 4. (a) In the absence of a declaration of war, in any case in which United States Armed Forces are introduced --

(1) into hostilities or into situations where imminent involvement in hostilities is clearly indicated by the circumstances;

(2) into the territory, airspace or waters of a foreign nation, while equipped for combat, except for deployment which relate solely to supply, replacement, repair, or training of such force; or

(3) in number which substantially enlarge United States Armed Forces equipped for combat already located in a foreign nation; the President shall submit within 48 hours to the Speak of the House of Representatives and to the President pro tempore of the Senate a report, in writing, setting forth --

(A) the circumstances necessitating the introduction of United States Armed Forces;

(B) the constitutional and legislative authority under which such introduction took place; and

(C) the estimated scope and duration of the hostilities or involvement. 
(b) The President shall provide such other information as the Congress may request in the fulfillment of its constitutional responsibilities with respect to committing the Nation to war and to the use of United States Armed Forces abroad.

(c) Whenever United States Armed Forces are introduced into hostilities or into any situation described in subsection (a) of this section, the President shall, so long as such armed forces continue to be engaged in such hostilities or situation, report to the Congress periodically on the status of such hostilities or situation as well as on the scope and duration of such hostilities or situation, but in no event shall he report to the Congress less of ten than once every six months. Congressional Action

Section 5. (a) Each report submitted pursuant to section 4 (a) (1) shall be transmitted to the Speaker of the House of Representatives and to the President pro tempore of the Senate on the same calendar day. Each report so transmitted shall be referred to the Committee on Foreign Affairs of the House of Representatives and to the Committee on Foreign Relations of the Senate for appropriate action. If, when the report is transmitted, the Congress has adjourned sine die or has adjourned for any period in excess of three calendar days, the Speaker of the House of Representatives and the President pro tempore of the Senate, if they deem it advisable (or if petitioned by at least 30 percent of the membership of their respective Houses) shall jointly request the President to convene Congress in order that it may consider the report and take appropriate action pursuant to this section.

(b) Within sixty calendar days after a report is submitted or is required to be submitted pursuant to section 4 (a) (1), whichever is earlier, the President shall terminate any use of United States Armed Forces with respect to which 
such report was submitted (or required to be submitted), unless the Congress (1) has declared war or has enacted a specific authorization for such use of United States Armed Forces, (2) has extended by law such sixty-day period, or (3) is physically unable to meet as a result of an armed attack upon the United States. Such sixty-day period shall be extended for not more than an additional thirty days if the President determines and certifies to the Congress in writing that unavoidable military necessity respecting the safety of United States Armed Forces requires the conginued use of such armed forces in the course of bringing about a prompt removal of such forces.

(c) Notwithstanding subsection (b), at any time that United States Armed Forces are engaged in hostilities outside the territory of the United States, its possessions and territories without a declaration of war or specific statutory authorization, such forces shall be removed by the President if the Congress so direct by concurrent resolution.

Congressional Priority Procedures for Joint Resolutions or Bill

Section 6. (a) Any joint resolution or bill introduced pursuant to section 5 (b) at least thirty calendar days before the expiration of the sixty-day period specified in such section shall be referred to the Committee on Foreign Affairs of the House of Representatives or the Committee on Foreign Relations of the Senate, as the case may be, and such committee shall report one such joint resolution or bill, together with its recommendations, not later than twenty-four calendar days before the expiration of the sixty-day period specicified in such section, unless such House shall otherwise determine by the yeas and nays.

(b) Any joint resolution or bill so reported shall become the pending business of the House in question (in the case of the Snate the time for debate shall be equally divided between the proponents and the opponents), and shall be 
voted on within three calendar days thereafter, unless such House shall otherwise determine by yeas and nays.

(c) Such a joint resolution or bill passed by one House shall be referred to the committee of the other House named in subsection (a) and shall be reported out not later than fourteen calendar days before the expiration of the sixty-day period specified in section 5 (b). The joint resolution or bill so reported shall become the pending business of the House in question and shall be voted on within three calendar days after it has been reported, unless such House shall otherwise determine by yeas and nays.

(d) In the case of any disagreement between the two Houses of Congress with respect to a joint resolution or bill passed by both Houses, conferees shall be promptly appointed and the committe of conference shall make and file a report with respect to such resolution or bill not later than four calendar days before the expiration of the sixty-day period specified in section 5 (b). In the event the conferees are unable to agree within 48 hurs, they shall report back to their respective Houses in disagreement. Notwithstanding any rule in either House concerning the printing of conference reports in the Record or concerning any delay in the consideration of such reports, such report shall be acted on by both Houses not later than the expiration of such sixty-day period. Congressional Priority Procedures for Concurrent Resolution

Section 7. (a) Any concurrent resolution introduced pursuant to section 5 (c) shall be referred to the Committee on Foreign Affairs of the House of Representatives or the Committee on Foreign Relations of the Senate, as the case may be, and one such concurrent resolution shall be reported out by such committee together with its recommendations within fifteen calendar days, unless such House shall otherwise determine by the yeas and nays. 
(b) Any concurrent resolution so reported shall become the pending business of the House in question (in the case of the Senate the time for debate shall be equally divided between the proponents and the opponents) and shall be voted on within three calendar days thereafter, unless such House shall otherwise determine by yeas and nays.

(c) Such a concurrent resolution passed by one House shall be referred to the committe of the other House named in subsection (a) and shall be reported out by such committee together with its recommendations within fifteen calendar days and shall thereupon become the pending business of such House and shall be voted upon within three calendar days, unless such House shall otherwise determine by yeas and nays.

(d) In the case of any disagreement between the two Houses of Congress with respect to a concurrent resolution passed by both Houses, conferees shall be promptly appointed and the committee of conference shall make and file a report with respect to such concurrent resolution within six calendar days after the legislation is referred to the committee of conference. Notwithstanding any rule in either House concerning the printing of conference reports in the Record or concerning any delay in the consideration of such reports, such report shall be acted on by both Houses not later than six calendar days after the conference report is filed. In the event the conferees are unable to agree within 48 hours, they shall report back to their respective Houses in disagreement. Interpretation of Joint Resolution

Section 8. (a) Authority to introduce United States Armed Forces into hostilities or situations wherein involvement in hostilities is clearly indicated by circumstances shall not be inferred -- 
(1) from any provision of law (whether or not in effect before the date of the enactment of this joint resolution), including any provision contained in any appropriation Act, unless such provision specifically authorizes the introduction of United States Armed Forces into hostilities or into such situations and states that it is intended to constitute specific statutory authorization within the meaning of this joint resolution; or

(2) from any treaty heretofore or hereafter ratified unless such treaty is implemented by legislation specifically authorizing the introduction of United States Armed Forces into hostilities or into such situations and stating that it is intended to constitute specific statutory authorization within the meaning of this joint resolution.

(b) Nothing in this joint resolution shall be construed to require any further specific statutory authorization to permit members of United States Armed Forces to participate jointly with member of the armed forces of one or more foreign countries in the headquarters operations of high-level military commands which were established prior to the date of enactment of this joint resolution and pursuant to the United Nations Charter or any treaty ratified by the United States prior to such date.

(c) For purposes of this joint resolution, the term "introduction of United States Armed Forces" includes the asignment of members of such armed forces to command, coordinate, participate in the movement of, or accompany the regular or irregular military forces of any foreign country or government when such military forces are engaged, or there exists an imminent threat that such forces will become engaged, in hostilities.

(d) Nothing in this joint resolution --

(1) is intended to alter the constitutional authority of the Congress or of the President, or the provisions of existing treaties; or 
(2) shall be construed as granting any authority to the President with respect to the introduction of United States Armed Forces into hostilities or into situations wherein involvement in hostilities is clearly indicated by the circumstances which authority he would not have had in the absence of this joint resoution.

Separability Clause

Section 9. If any provision of this joint resoution or the application thereof to any person or circumstances is held invalid, the remainder of the joint resolution and the application or such provision to any other person or circumstances shall not be affected thereby.

Effectve Date

Section 10. This joint resolution shall take effect on the date of its enactment.

* Became law on November 7, 1973 as both Houses or Congress overrode the Presidential veto of October $24,1973$. 